LOCALIZAÇÃO ESPACIAL DE UNIDADES DE INFORMAÇÃO PARA O DESLOCAMENTO DE PEDESTRES UTILIZANDO ISOVISTAS

ADRIANA CRISTINA DA SILVA SOUZA

DISSERTAÇÃO DE MESTRADO EM TRANSPORTES DEPARTTAMENTO DE ENGENHARIA CIVIL E AMBIENTAL 
UNIVERSIDADE DE BRASÍLIA

FACULDADE DE TECNOLOGIA

DEPARTAMENTO DE ENGENHARIA CIVIL E AMBIENTAL

LOCALIZAÇÃO ESPACIAL DE UNIDADES DE INFORMAÇÃO PARA O DESLOCAMENTO DE PEDESTRES UTILIZANDO ISOVISTAS

ADRIANA CRISTINA DA SILVA SOUZA

ORIENTADOR: PROF. DR. PASTOR WILLY GONZALES TACO

DISSERTAÇÃO DE MESTRADO EM TRANSPORTES

PUBLICAÇÃO: T.DM-004A/2015

BRASÍLIA/DF: ABRIL/2015 
UNIVERSIDADE DE BRASÍLIA

FACULDADE DE TECNOLOGIA

DEPARTAMENTO DE ENGENHARIA CIVIL E AMBIENTAL

\section{LOCALIZAÇÃO ESPACIAL DE UNIDADES DE INFORMAÇÃO PARA O DESLOCAMENTO DE PEDESTRES UTILIZANDO ISOVISTAS}

\section{ADRIANA CRISTINA DA SILVA SOUZA}

DISSERTAÇÃO DE MESTRADO SUBMETIDA AO PROGRAMA DE PÓS-GRADUAÇÃo EM TRANSPORTES DO DEPARTAMENTO DE ENGENHARIA CIVIL E AMBIENTAL DA UNIVERSIDADE DE BRASÍlIA, COMO PARTE DOS REQUISITOS NECESSÁRIOS PARA A OBTENÇÃO DO GRAU DE MESTRE.

APROVADA POR:

$\overline{\text { PROF. DR. PASTOR WILLY GONZALES TACO }}$ (ORIENTADOR)

PROF. PhD. PAULO CÉSAR MARQUES DA SILVA (EXAMINADOR INTERNO)

PROF. DR. VALÉRIO AUGUSTO SOARES DE MEDEIROS (EXAMINADOR EXTERNO) 


\section{FICHA CATALOGRÁFICA}

\section{ADRIANA CRISTINA DA SILVA SOUZA}

Localização espacial de unidades de informação para o deslocamento de pedestres utilizando Isovistas.

xiv, 100p., 210 x $297 \mathrm{~mm}$ (ENC/FT/UnB, Mestre em Transportes, 2015).

Dissertação de Mestrado - Universidade de Brasília. Faculdade de Tecnologia.

Departamento de Engenharia Civil e Ambiental.

1. Pedestres

2. Forma Urbana

3. Sintaxe Espacial

4. Isovistas

5. Orientação Espacial

6. Unidade de Informação

I. ENC/FT/UnB

II. Título (série)

\section{REFERÊNCIA BIBLIOGRÁFICA}

SOUZA, A. C. S. (2015). Localização espacial de unidades de informação para o deslocamento de pedestres utilizando Isovistas. Dissertação de Mestrado em Transportes, Publicação T.DM-004A/2015, Departamento de Engenharia Civil e Ambiental, Faculdade de Tecnologia, Universidade de Brasília, DF, 100p.

\section{CESSÃO DE DIREITOS}

\section{AUTORA: Adriana Cristina da Silva Souza}

TÍTULO: Localização espacial de unidades de informação para o deslocamento de pedestres utilizando as Isovistas.

GRAU: Mestre

ANO: 2015

É concedida à Universidade de Brasília permissão para reproduzir cópias desta dissertação de mestre e para emprestar ou vender tais cópias somente para propósitos acadêmicos e científicos. A autora reserva outros direitos de publicação e nenhuma parte dessa dissertação de mestrado pode ser reproduzida sem autorização por escrito da autora.

Adriana Cristina da Silva Souza souza.ppgt@gmail.com

SQN 407 Bloco G - Asa Norte

Brasília - Distrito Federal 
O correr da vida embrulha tudo,

A vida é assim: esquenta e esfria,

Sossega e depois desinquieta.

O que ela quer da gente é coragem.

Guimarães Rosa 


\section{DEDICATÓRIA}

Dedico a minha querida mãe Cristina (em memória), aos meus professores, amigos e familiares que me ensinaram, apoiaram e acreditaram no meu trabalho. 


\section{AGRADECIMENTOS}

Agradeço primeiramente a minha vida e aos meus avós (Regina e Abel) pelo amor recebido. Ao meu orientador Prof. Dr. Pastor Willy Gonzales Taco, por todo apoio, ajuda e compreensão para a elaboração deste estudo.

Aos Professores: Paulo César Marques da Silva (PhD) e Valério Augusto Medeiros (Dr.) pela disponibilidade, dedicação e confiança.

A todos os professores que disponibilizaram seus conhecimentos e seus verdadeiros desejos de ensinar.

Ao CNPq pela viabilidade do estudo.

Aos meus amigos-família, Vânia, Vera, Wagner, Rômulo e Fernando pelo amor, carinho e confiança.

Aos meus amigos que me acompanharam e incentivaram desde o início desta jornada, em especial a Paulinha Pedestre, Alessandro, Luíz, Júlia, Cássio, Rafaella, Érika, Veri, Fabiana, César, Talitha, Layla, Tissa, Karininha, Juan Pablo e Edgar.

Aos meus amigos do programa de Pós-graduação em Transportes, especialmente para a turma de 2013 - Aline, Rony, Luca, Hudson, Edwin, Wesley, Jean, Gerardo, Gal, Walysson, Emmanuel e Leonel e a querida Lucinete.

Ao Departamento de Trânsito do Distrito Federal e a equipe da Secretaria de Estado de Gestão do Território e Habitação - Anamaria, Aline, Olga, Letícia e Michel.

Agradeço tudo e todos que de alguma forma fizeram parte da construção desse projeto, minha verdadeira gratidão! 


\section{RESUMO}

O estudo explora por meio da ferramenta Isovista, oriunda da Teoria da Lógica Social do Espaço, em que medida a localização das informações no espaço urbano afeta a continuidade e orientação do deslocamento do pedestre. O objetivo do estudo foi desenvolver um método para localização espacial de unidades de informações em estações de transporte público. Partindo da premissa que as informações, quando bem localizadas, tendem a proporcionar ao pedestre mais clareza da composição do espaço, permitindo, portanto, um deslocamento contínuo e orientado. Para tanto foram propostos três objetivos específicos: i) analisar o desempenho configuracional das áreas de influência das estações, ressaltando que a configuração diz respeito à conformação das relações entre as partes da cidade; $i i$ ) identificar os pontos (localização) de melhor fornecimento de informações ao pedestre; e, iii) aplicar o método nas estações de transporte público de Brasília (Metrô). As cinco estações estudadas podem ser classificadas em dois grupos distintos, o primeiro apresentando quase uma ausência de infraestrutura para o pedestre, forte segregação do uso do solo, grandes espaços vazios, pouca identidade, e também, poucos pontos estratégicos de unidades de informações. O segundo com uma infraestrutura melhor para os pedestres, apresentando rotas com faixas elevadas, uso misto do solo, variedades de comércios, diversidade de pessoas e corredores com pontos estratégicos de informações. As análises da forma urbana, nas áreas de influência das estações, por meio de suas permeabilidades e barreiras apontaram o que muitos estudos afirmam em relação às cidades mais vivas, ou seja, mais miscigenadas, sustentáveis, convidativas ao deslocamento a pé, aumentando dessa forma a segurança e integração de espaços e pessoas. Aos gestores, seguindo um viés mais estratégico, o método traz a possibilidade de intervenções urbanas no sentido de integrar o pedestre com o sistema de transporte público, por meio da correta localização das unidades de informações espalhadas em pontos estratégicos, articulando seu deslocamento de um ponto do sistema de transporte público para o seu destino final. Compreender e estudar as cidades como um organismo vivo, onde tudo esta interligado, não é uma tarefa fácil, entretanto é de fundamental importância para enxergarmos soluções sistêmicas em problemas que, muitas vezes, parecem isolados.

Palavras-chave: Pedestres, Forma Urbana, Sintaxe Espacial, Isovistas, Orientação Espacial, Unidade de Informação. 


\begin{abstract}
The study analyzes through the Isovista tool, derived from the Theory of Social Logic of Space how the location of information in the urban space affects the continuity and orientation of pedestrian displacement. The aim of the study was to develop a method for location spatial information units in public transport stations. Assuming that the information, when properly located, tend to provide the pedestrian more clearly the composition of space, allowing therefore a continuous and oriented displacement. Therefore, have been proposed three specific objectives: i) to analyze the configuration of the areas of influence of public transport stations; ii) identify the points (location) of better offering information to the pedestrian; and, iii) apply the method at public transport stations Brasilia (Metro). The five stations studied can be classified into two groups, the first with almost an absence of infrastructure for pedestrian, strong segregation of land use, large voids, little identity, and also a few strategic points of information units. The second with a better infrastructure for pedestrians, with routes with high tracks, mixed land use, variety of trades, and diversity of people and corridors with strategic points of information. The analysis of urban form in the areas of influence of the stations, through its permeability and barriers showed what many studies indicate about the alive cities, this is, more miscegenated, sustainable, inviting to walk, thereby increasing and integrating the safety spaces and people. For the managers, following a strategic subject, the method brings the possibility of urban interventions to integrate the pedestrian with the public transport system through the correct location of the information units scattered at strategic points, articulating the displacement of a point of public transport system to its final destination. Understand and study cities as a living organism, where everything is interconnected, it is not an easy task, however it is extremely important to achieve systemic solutions to problems that often seem isolated.
\end{abstract}

Keywords: Pedestrians, Urban Form, Space Syntax, Isovist, Space Orientation, Information Unit. 


\section{SUMÁRIO}

1. INTRODUÇÃO

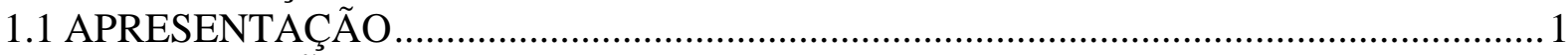

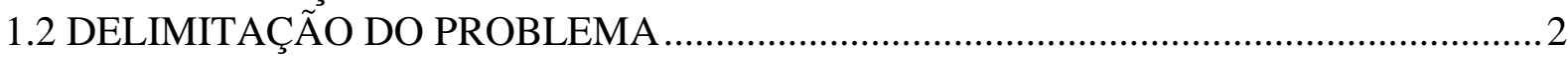

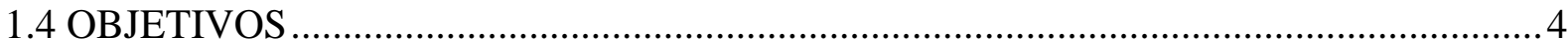

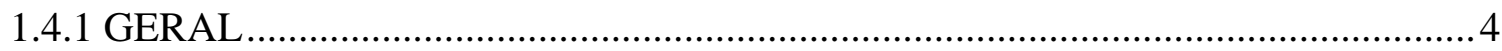

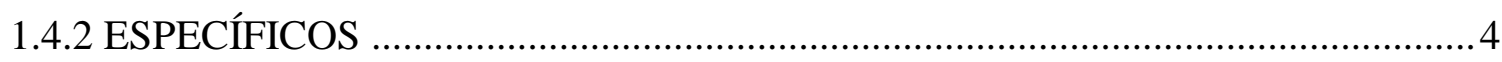

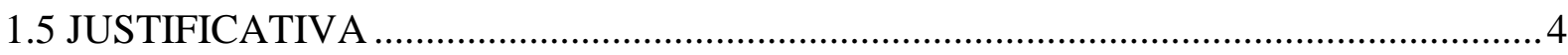

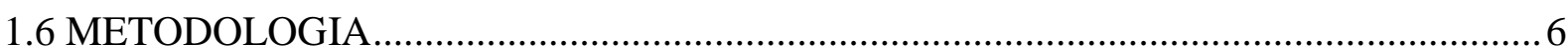

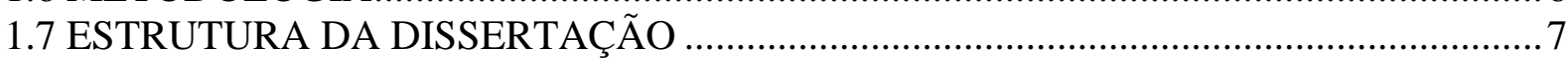

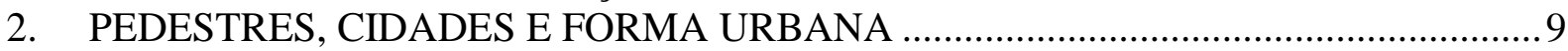

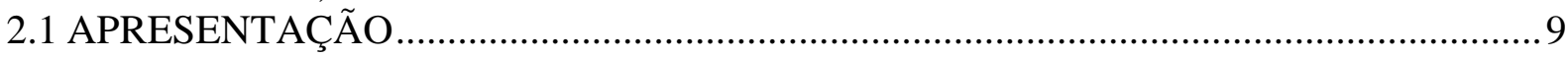

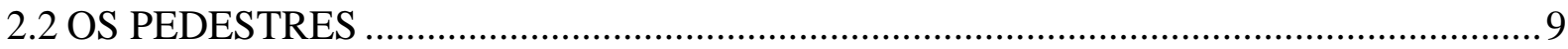

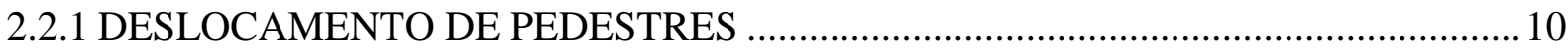

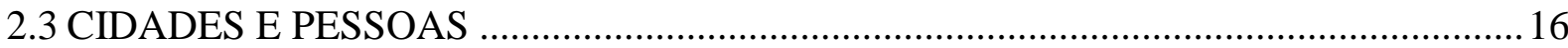

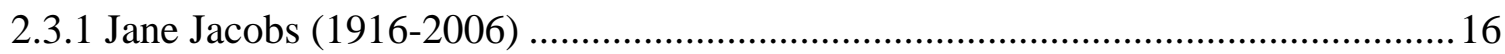

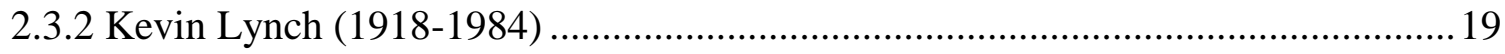

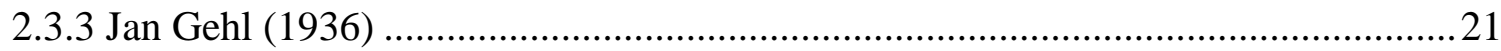

2.4 FORMA URBANA E MAPAS DE SINALIZAÇÕES ................................................. 23

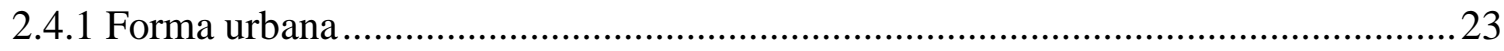

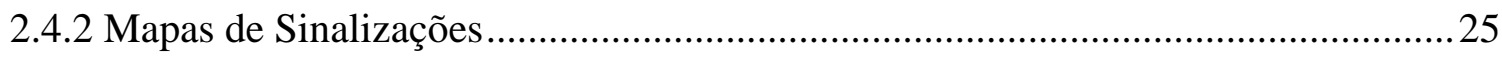

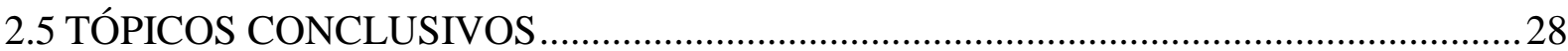

3. FERRAMENTA PARA IDENTIFICAÇÃO DE CARACTERÍSTICAS ESPACIAIS

RELEVANTES AO DESLOCAMENTO DE PEDESTRES: SINTAXE ESPACIAL -

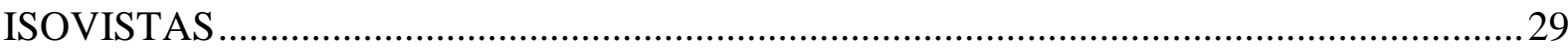

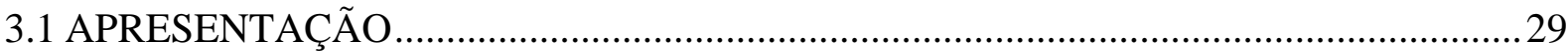

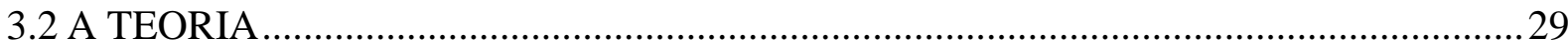

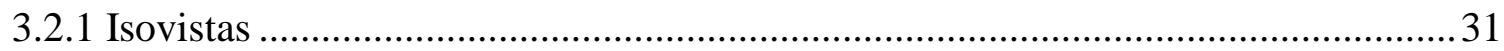

3.2.2 Pesquisas realizadas com a utilização das Isovistas ................................................. 33

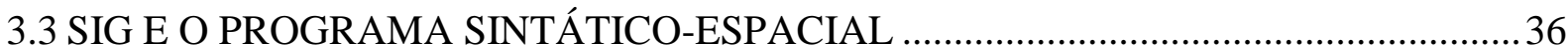

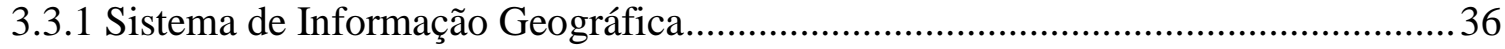

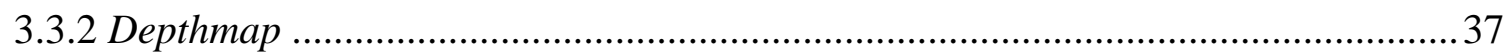

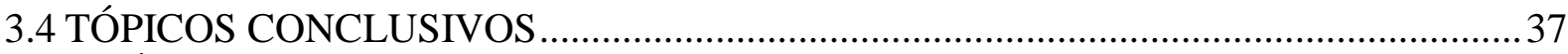

4. MÉTODO PARA DETERMINAÇÃO DA LOCALIZAÇÃO DE UNIDADES DE

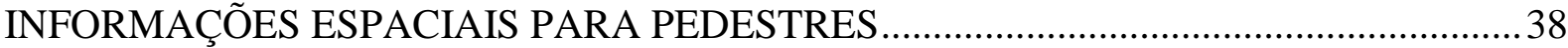

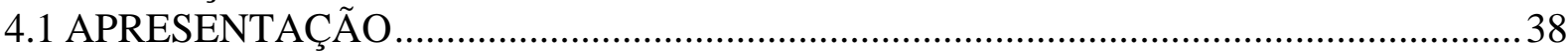

4.2 CONSIDERAÇÕES CONCEITUAIS PARA A UTILIZAÇÃO DO MÉTODO ...............39

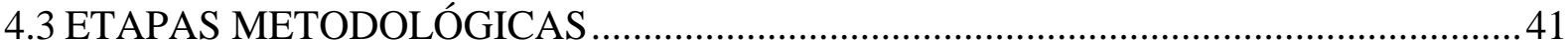

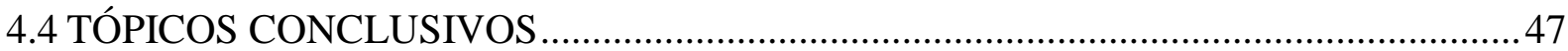

5. APLICAÇÃO DO ESTUDO: ESTAÇÕES METROVIÁRIAS DO DISTRITO

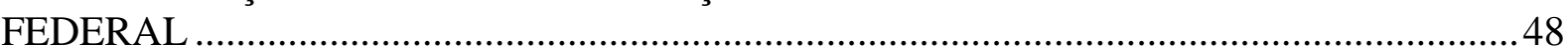

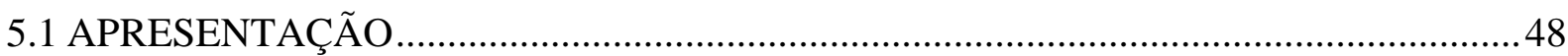

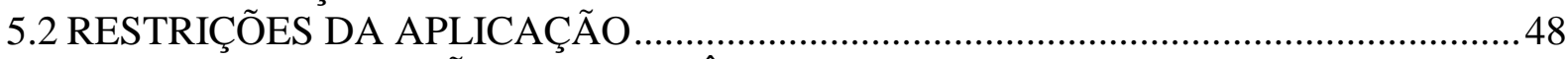

5.3 CONTEXTUALIZAÇÃO DO METRÔ DO DISTRITO FEDERAL ................................ 49

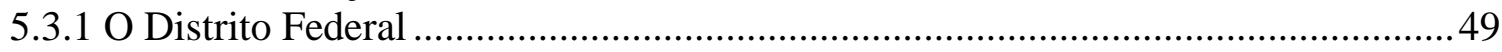




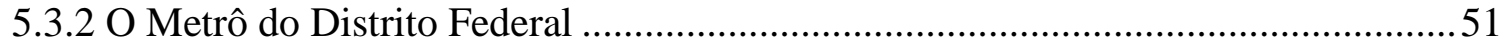

5.4 APLICAÇÃO DO ESTUDO DE CASO NO METRÔ DO DISTRITO FEDERAL ..........52

5.4.1 Descrição das estações e classificação .....................................................................53

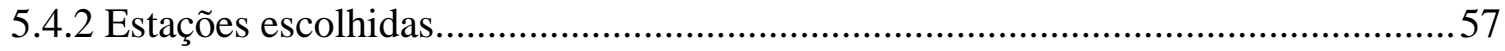

5.4.3 Obtenção das Isócronas das Estações escolhidas ................................................... 66

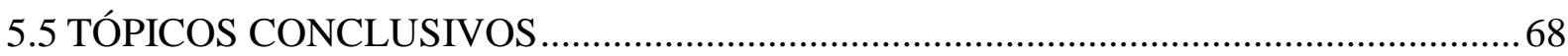

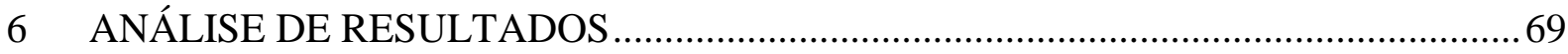

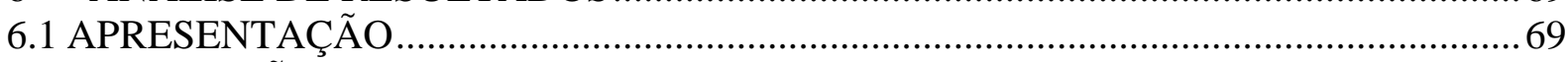

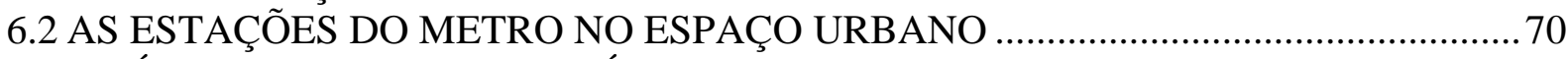

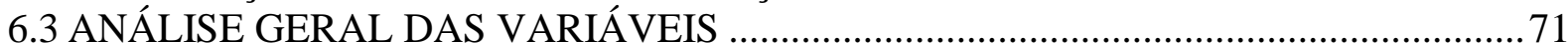

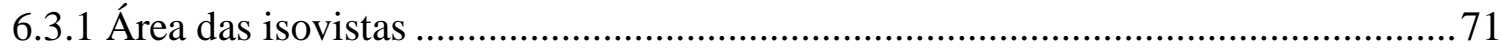

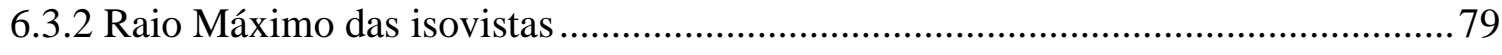

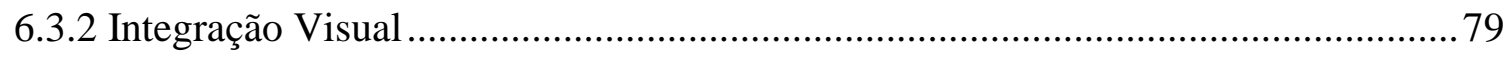

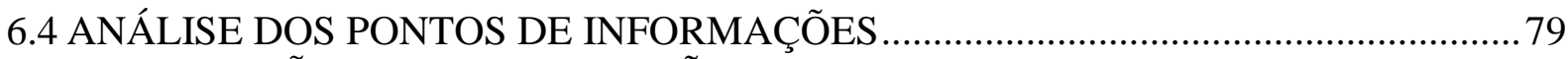

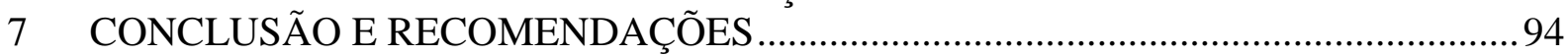

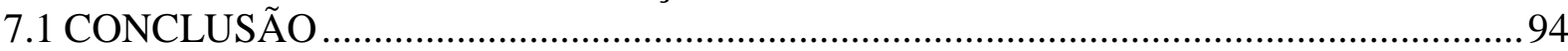

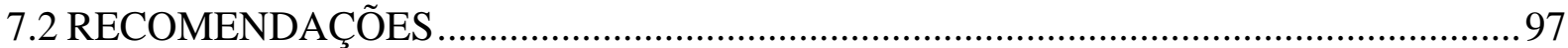

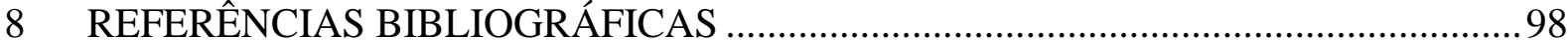




\section{Lista de Figuras}

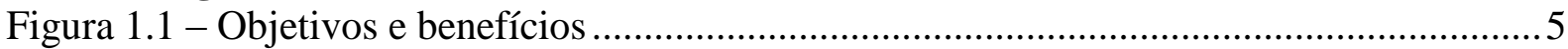

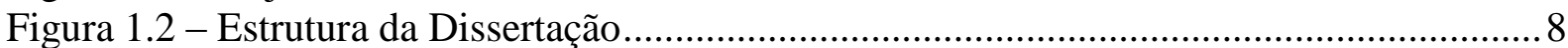

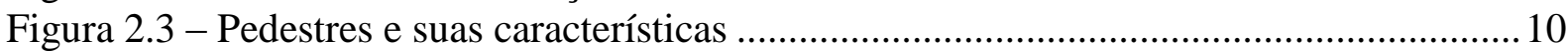

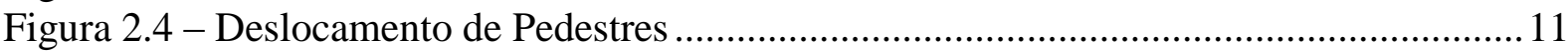

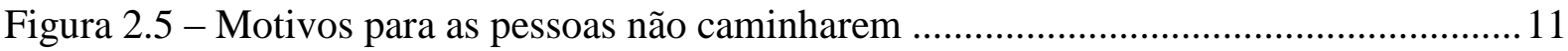

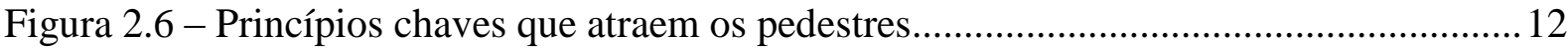

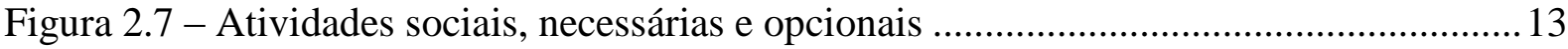

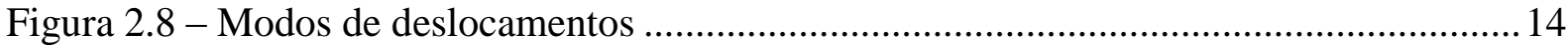

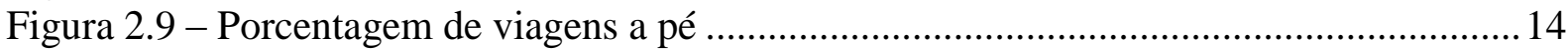

Figura 2.10 - Principal meio de transporte usado no deslocamento na cidade ........................ 15

Figura 2.11 - Exemplo de um Mapa de Sinalização ................................................................2 27

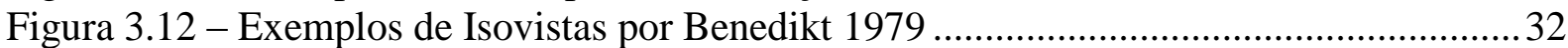

Figura 4.13 - Passo a passo do método para localização da sinalização ao pedestre ...............42

Figura $4.14-1^{\mathrm{a}}$ fase - Caracterizar a área do Sistema de Transporte escolhido....................... 43

Figura $4.15-2^{\mathrm{a}}$ fase - Categorizar a área de influência e escolher as estações.........................44

Figura $4.16-3^{\text {a }}$ fase - Construir o modelo da rede de pedestres para análises ...................... 46

Figura $4.17-4^{\text {a }}$ fase - Verificar as áreas com maior visibilidade ao pedestre ..........................46

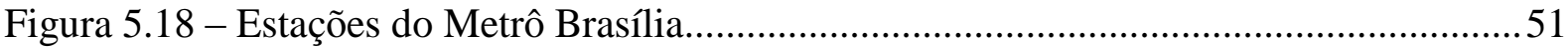

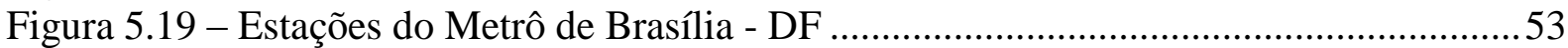

Figura 5.20 - Porcentagem de áreas construídas conforme uso do solo .................................54

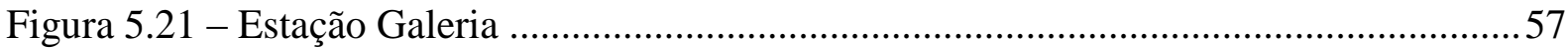

Figura 5.22 - Classificação do uso do solo - Galeria ..............................................................5 57

Figura 5.23 - Área de influência da estação Galeria ............................................................58

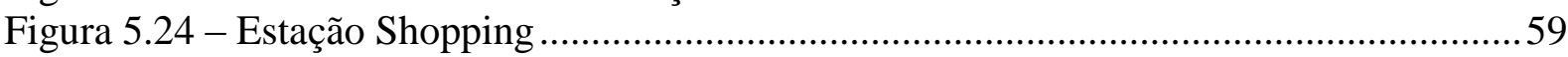

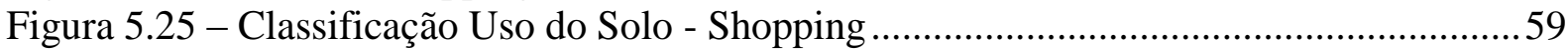

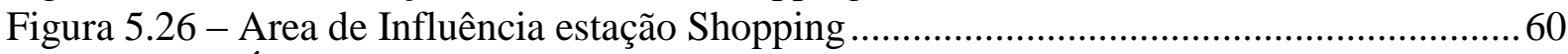

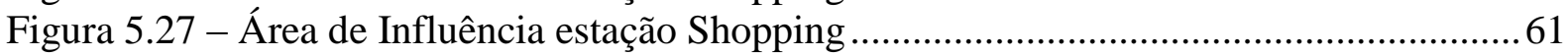

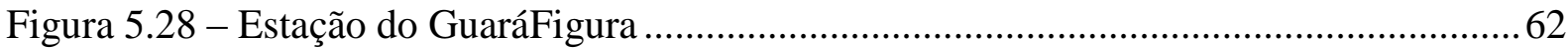

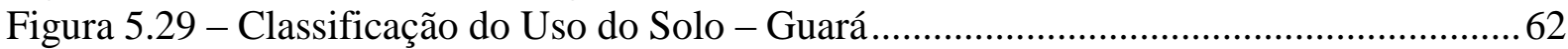

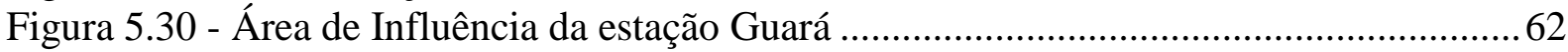

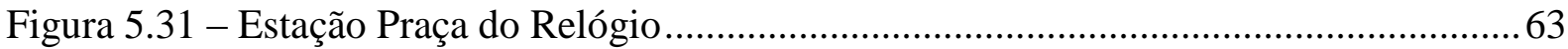

Figura 5.32 - Classificação Uso do Solo - Praça do Relógio.....................................................63

Figura 5.33 - Área de Influência da estação Praça do Relógio ..................................................64

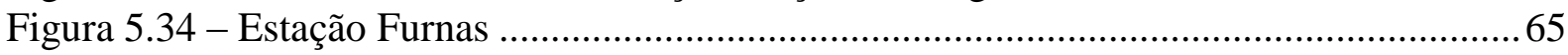

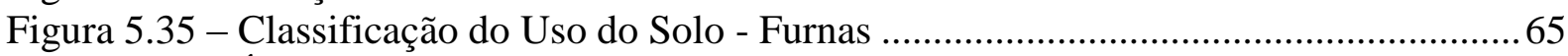

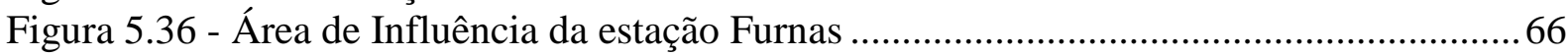

Figura 5.37 - Isócronas (5, 10 e 15 minutos) na área de influência das estações ....................67

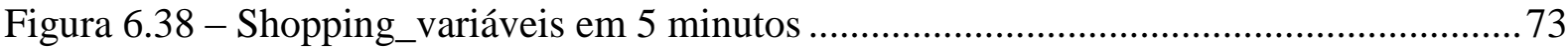

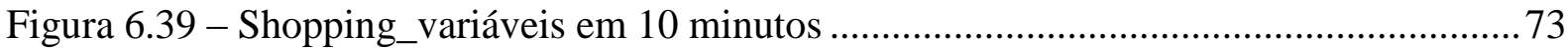

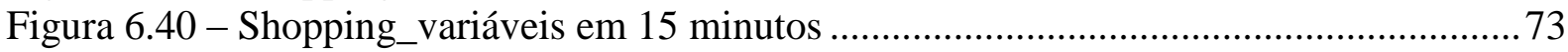

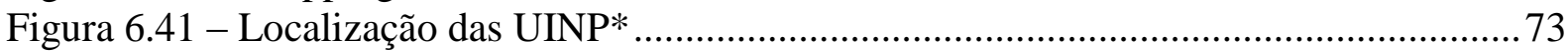

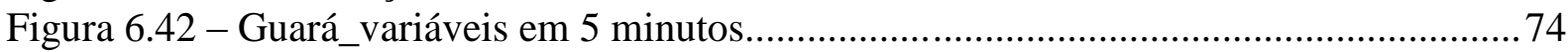

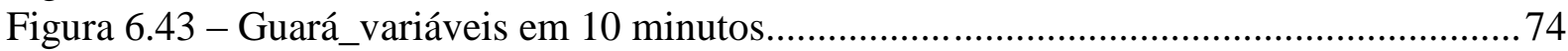

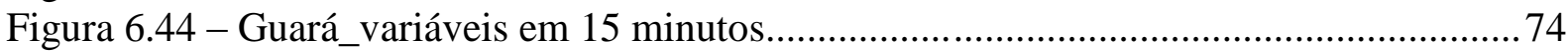

Figura 6.45 - Localização das UINP* ........................................................................ 74

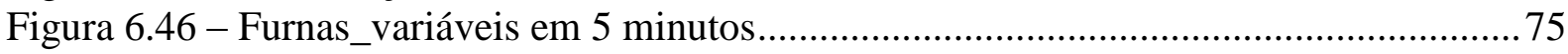

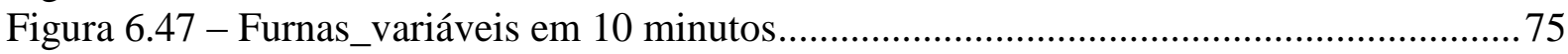

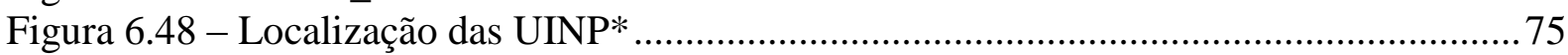

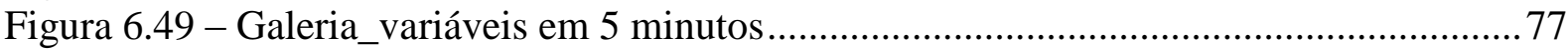




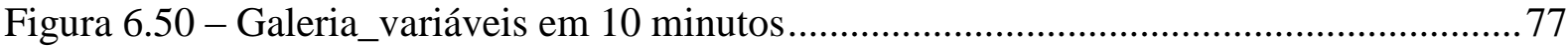

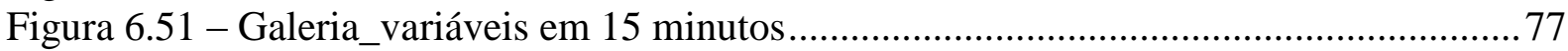

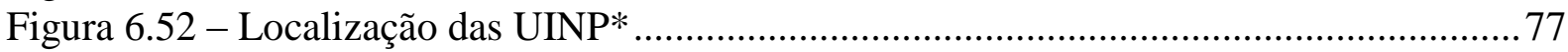

Figura 6.53 - Praça do Relógio_variáveis em 5 minutos ................................................... 78

Figura 6.54 - Praça do Relógio_variáveis em 10 minutos ..................................................... 78

Figura 6.55 - Praça do Relógio_variáveis em 15 minutos................................................... 78

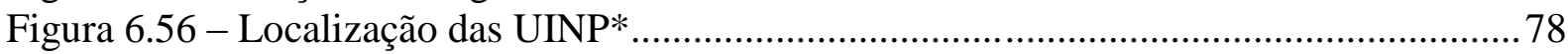

Figura 6.57 - Localização de Unidades de Informações _Shopping .....................................8 82

Figura 6.58 - Localização de Unidades de Informações _Shopping ..................................... 83

Figura 6.59 - Localização de Unidades de Informações _Guará .............................................. 84

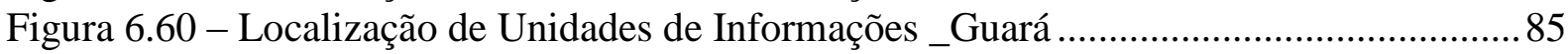

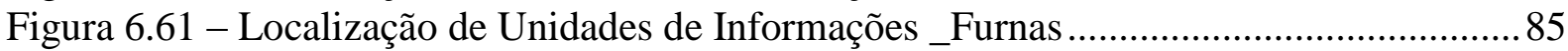

Figura 6.62 - Localização de Unidades de Informações _Furnas ............................................85

Figura 6.63 - Localização de Unidades de Informações _Galeria ...........................................90

Figura 6.64 - Localização de Unidades de Informações _Galeria ............................................90

Figura 6.65 - Localização de Unidades de Informações_Praça do Relógio ............................ 91

Figura 6.66 - Localização de Unidades de Informações_Praça do Relógio .............................92

Figura 6.67 - Localização de Unidades de Informações_Praça do Relógio ..............................93 


\section{Lista de Tabelas}

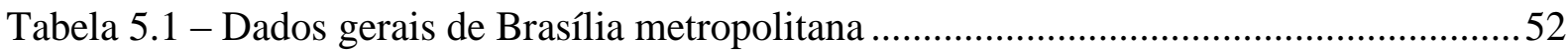

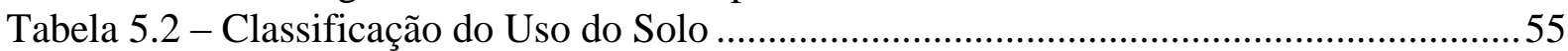

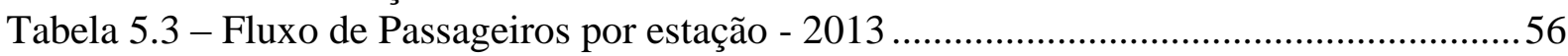

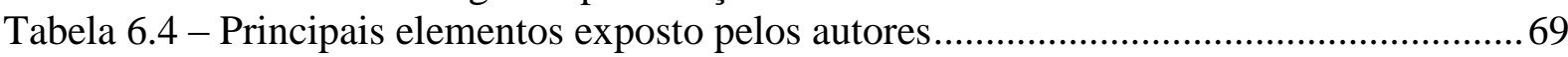

Tabela 6.5 - Classificação quanto ao uso de solo das áreas de influência das estações ...........71 


\section{INTRODUÇÃO}

\subsection{APRESENTAÇÃO}

O transporte motorizado, durante décadas no Brasil, tem sido privilegiado em detrimento ao transporte não motorizado. Devido ao privilégio, há melhor infraestrutura para os meios rodoviários de transporte, principalmente o automóvel particular, em comparação com os modos não motorizados (deslocamento a pé ou por bicicleta). Nota-se um descuido por parte dos órgãos governamentais com a mobilidade urbana e com o funcionamento da cidade como um todo. Falar sobre um transporte coletivo de qualidade, o uso moderado ou compartilhado do automóvel, ou mesmo uma melhor infraestrutura para os transportes não motorizados, causa estranheza e inquietações não só para os governantes, como também, para uma grande parte da população brasileira.

A inquietude quando se observa esse diagnóstico é entender como o governo brasileiro pretende resolver os problemas de mobilidade urbana se ainda privilegiam um único modo de transporte. É fato que a priorização ao modo rodoviarista de transporte desencadeou uma dificuldade de circulação/movimentação de pessoas que utilizam modos não motorizados para se deslocarem nas cidades, e essa preterização de infraestrutura para os pedestres e ciclistas, principalmente quando o assunto é localização de informações, rotas ou caminhos mais seguros, provoca insegurança no sentindo de falta de domínio do espaço, falta de préconfiguração de como o espaço se estrutura, ou seja, a falta de apropriação do espaço e descontinuidade no deslocamento.

Vale lembrar que as informações disponibilizadas aos usuários de transportes, seja o modo motorizado ou não motorizado, são necessárias para que estes indivíduos possam organizar melhor os seus deslocamentos no tempo e espaço. No modo motorizado, o sistema de informação para o transporte público pode ser definido como um sistema capaz de promover a interação inteligente entre os usuários dos sistemas de transporte, os veículos e a infraestrutura disponível (Silva, 2000). Além disso, de acordo com Cutolo (2003), seu principal objetivo é promover a mobilidade, pois a informação permite que as pessoas planejem e definam seus deslocamentos pela cidade.

Entretanto, os deslocamentos feitos por modos não motorizados, principalmente o deslocamento a pé, sofrem com a falta de informação e de infraestrutura observáveis na 
grande maioria das cidades brasileiras devido à falta de calçadas, iluminação, placas informativas ou mesmo balcões de informações aos pedestres. Herce (2009) destaca que as pessoas, além de serem transportadas por algum modo, também podem transportar a si mesmas. A constatação é que os pedestres são preteridos de segurança, conforto e informação, enquanto os modos motorizados possuem espaços físicos cada vez maiores e sinalizações mais aprimoradas. Unidades de informações disponibilizadas aos pedestres podem reduzir a incerteza e clarificar a ambiguidade. Os espaços públicos são frequentados por pessoas e são elas que necessitam se apropriar destes espaços com informação, acessibilidade, conforto, segurança e equidade. Por isso se faz necessário recuperar esses espaços em termos de disponibilidade de informação, pois além de torná-los mais convidativos, proporcionará às pessoas um deslocamento com maior agilidade.

As informações podem ser apresentadas em mapas por constituírem uma representação da paisagem por meio de símbolos, cores, traços e sinais, e alocados em locais específicos podem ser facilmente interpretados pelos pedestres. $\mathrm{O}$ posicionamento adequado de mapas dispostos em ruas, estações de metrô e ônibus, é uma oportunidade para testar mudanças qualitativas na percepção do indivíduo sob o aspecto de facilidade de orientação espacial em uma região. Possivelmente haverá uma melhora significativa na qualidade dos deslocamentos, compreendendo uma maior acessibilidade, segurança e rapidez. Favorecer a acessibilidade e a mobilidade de pedestres, que são os usuários mais vulneráveis do sistema de transportes, devido a sua necessidade de deslocamento (condição física) e a ausência de uma infraestrutura proporcionada pelo tamanho das calçadas, iluminação, segurança e informações, é uma obrigação do governo e um direito da sociedade.

\subsection{DELIMITAÇÃO DO PROBLEMA}

O deslocamento a pé é um dos principais modos utilizados pelas pessoas. No entanto, o espaço público, adaptado para a utilização de modos mais velozes, faz com que essa capacidade básica do ser humano se torne uma atividade perigosa, e de difícil mensuração de espaço-tempo, tornando-a sem atratividade (Melo 2005). Para Gehl (2013), a observação das necessidades das pessoas que utilizam as cidades, permite reforçar as áreas de pedestres com uma política urbana integrada para desenvolver cidades vivas, seguras, sustentáveis e saudáveis. 
Qualquer pessoa ao se deslocar no espaço organiza os seus pensamentos, mesmo aqueles que querem passear sem destino buscam referências e orientação no deslocamento. Para alguns, as informações contidas nos espaços públicos, quando encontradas, são suficientes para se orientarem e se deslocarem, para outros, além dessas informações há a necessidade de buscar na memória as informações guardadas (Lynch, 2011). Para Saboya et. al., (2011) o "moverse" pelo espaço está diretamente relacionado ao "ver". Apesar de ser perfeitamente possível mover-se pelo espaço sem vê-lo, é inegável que a capacidade de enxergar o espaço exerce forte influência sobre o ato de mover-se por ele. A frase reforça a questão de segurança psíquica e de domínio espacial, sendo um contraponto à perspectiva labiríntica, que afeta as sensações de apreensão do ser humano. Em relação às informações contidas no espaço, é importante ressaltar que elas podem ser agrupadas conforme as necessidades dos pedestres, e estes podem ser divididos em três grupos: pedestres locais, potenciais e usuários não habituais ou turistas.

Começando com os pedestres locais que não necessitam de muita informação para o seu deslocamento, pois são conhecedores da região; em seguida, os pedestres potenciais que podem ser classificados como os habitantes que conhecem a cidade, porém se deslocam em áreas desconhecidas e também como àqueles que não têm o costume de utilizar esse modo; por último, os pedestres turistas (usuário não habitual) que são os visitantes, ou seja, desconhecem totalmente a cidade e suas regiões, necessitando de informações mais completas e detalhadas.

Hillier e Hanson (1984), e Holanda (2002), por exemplo, consideram o espaço como um sistema de barreiras e permeabilidades que condicionam o movimento das pessoas, ou seja, a configuração urbana, quando não bem estruturada, seria o primeiro contribuinte para um problema de deslocamento de pedestres e desta forma as informações quando bem localizadas serveriam como corretores de uma confiração urbana que não é propícia para uma legibilidade clara e prévia.

As informações disponíveis nas vias servem para regular, advertir e orientar os usuários de transporte público e privado. Em relação aos pedestres, o diagnóstico das informações, quando encontradas, não promovem segurança nem confiança para o deslocamento a pé, favorecendo ainda mais o deslocamento realizado pelo transporte motorizado, principalmente o automóvel. Porém, seja qual for o tipo de transporte utilizado, normalmente o modo de 
acesso a serviços essenciais como saúde, educação e emprego, e também para as atividades sociais é o deslocamento a pé. (Melo, 2005).

A falta de informação, localizadas de forma estratégica para os meios de transporte, pode ser considerada um problema na temática mobilidade urbana. Para Silva (2007) o problema envolve dois aspectos: a falta de informação dispostas em mapas de orientabilidade e a falta de habilidade na leitura de mapas pelas pessoas. Os mapas podem ter características técnicas específicas para atender desde as mais complexas informações como cartas para navegação aérea, até as mais simples como mapas de orientação espacial para pedestres. O espaço em si precisa apresentar unidades de informações (elementos físicos) que permitam o deslocamento com propriedade e segurança. Diante desse contexto, a questão de pesquisa deste estudo é:

\section{Em que medida a localização das informações no espaço urbano afeta a continuidade e orientação do deslocamento do pedestre?}

\subsection{OBJETIVOS}

\subsubsection{GERAL}

Desenvolver um método para localização espacial de unidades de informações, fazendo uso da Sintaxe Espacial - Isovistas, no intuito de promover um deslocamento contínuo e orientado ao pedestre em áreas de influência das estações do Sistema de Transporte Público.

\subsubsection{ESPECÍFICOS}

i) analisar o desempenho configuracional das áreas de influência das estações;

ii) identificar os pontos de melhor localização de unidades de informações aos pedestres;

iii) aplicar o método nas estações de transporte público de Brasília (Metrô).

\subsection{JUSTIFICATIVA}

Entende-se que a localização das unidades de informações, quando bem localizadas, tendem a proporcionar ao pedestre mais clareza da composição do espaço, permitindo, portanto, maior apropriação das imediações do espaço, o que possibilita um deslocamento continuo e orientado. 
O deslocamento a pé além de ser um modo não poluente, permite que as pessoas se exercitem quando se movem de um lugar para outro. As pessoas podem começar a praticá-lo em curtas distâncias, porém se forem estimuladas podem não só aumentar a quantidade como também às distâncias percorridas, e desta forma trazer benefícios à saúde. É certo que, em todos os modos do sistema de transportes, é notória a relevância da informação como ferramenta implícita de organização/orientação espacial. Algumas informações são absolutamente necessárias e outras bastante úteis para que haja uma apropriação do espaço. Com informações adequadas e com a prática adquirida, as pessoas podem buscar novas rotas, pois já se sentirão confiantes para se apropriarem do espaço com rapidez, atingindo uma melhor interação com o ambiente e uma melhor qualidade na caminhada.

O usuário não habitual (turistas), por exemplo, que necessitam de informações mais detalhadas de uma cidade, ao se sentirem capacitados por meio de informações, disponibilizadas adequadamente, se sentem mais seguros e podem planejar os deslocamentos com maior confiança e otimização de tempo.

Na Figura 1.1 são destacados os objetivos e benefícios da disponibilização adequada de informações espaciais para o deslocamento de pedestres nos espaços públicos.

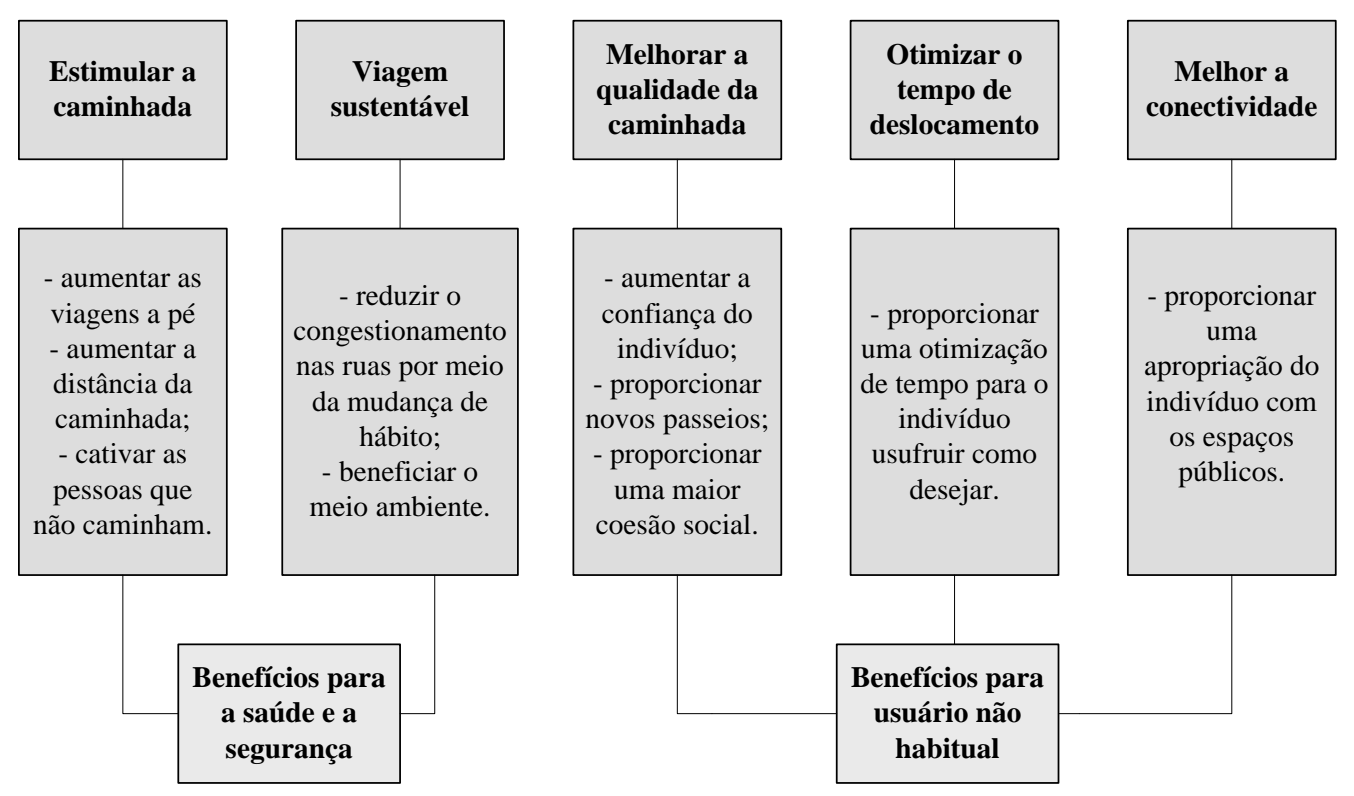

Figura 1.1 - Objetivos e benefícios 
Os indivíduos são pedestres antes e/ou depois de utilizarem os modos de transportes e as informações deveriam estar disponibilizadas para auxiliarem em seu percurso e fomentarem o deslocamento a pé.

Por meio das Isovistas, ferramenta da Sintaxe Espacial, é possível gerar o campo de maior visibilidade ao pedestre. Os pontos que podem ser vistos de vários lugares fornecem informações frequentes sobre onde um observador se encontra e, por isso, costumam ser utilizados como elementos de referência. O orientar-se de uma pessoa no aspecto geográfico significa o conhecimento de onde está e para qual o sentido de movimentação irá seguir. Além disso, a possibilidade de visualizar previamente informações em pontos próximos ao destino torna a tarefa de deslocar-se mais contínua e orientada.

\subsection{METODOLOGIA}

A metodologia da dissertação será dividida em quatro etapas descritas abaixo:

\section{$1^{\text {a }}$ Etapa}

Nesta primeira etapa o objetivo é contextualizar o fenômeno e o objeto de estudo por meio do referencial teórico. O levantamento bibliográfico será realizado por meio dos sites das bibliotecas online das universidades nacionais e internacionais; dos estudos científicos desenvolvidos e disponibilidades na Web of Science; pelo acervo do programa de pósgraduação de Transporte da Universidade de Brasília; livros que abordem temas como pedestres, orientação espacial, informações espaciais, sintaxe espacial entre outros, para assim definir o conceito de pedestres e seus deslocamentos; forma urbana; e mapas de sinalização. Serão também abordados os conceitos básicos das ferramentas que serão utilizadas na pesquisa como a Isovista oriunda da Teoria da Lógica Social do Espaço ou Sintaxe Espacial.

\section{$2^{\text {a }}$ Etapa - Desenvolvimento do método}

O desenvolvimento do método contemplará quatro fases:

$1^{a}$ fase: Caracterizar a área de estudo de todas as estações do sistema de transporte público: Coletar dados para caracterizar a área de influência de todas as estações do Sistema de Transporte Público escolhido para a pesquisa. 
$2^{\text {a }}$ fase: Selecionar as estações do sistema de transporte público: Tratar e classificar os dados para escolher as estações que serão estudadas após sua caracterização (realizada na $1^{\mathrm{a}}$ fase).

$3^{a}$ fase: Construir o modelo de rede de caminhos para o pedestre da área de influência da estação: Aplicar e processar os dados no Sistema de Informação Geográfica - SIG - para construir o modelo da rede de pedestres.

$4^{\text {a }}$ fase: Determinar as áreas de influências das estações de maior visibilidade e integração: Identificar e analisar as áreas com maior visibilidade ao pedestre no programa Depthmap ${ }^{\circledR}$.

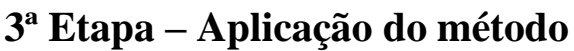

O método será um estudo de caso aplicado no Sistema de Transporte Metroviário de Brasília (Metro-DF).

\section{$4^{\text {a }}$ Etapa - Análise dos resultados}

A última etapa apresentará os resultados e discussões da aplicação do método no estudo de caso.

\subsection{ESTRUTURA DA DISSERTAÇÃO}

A dissertação contará com a Introdução e mais 6 capítulos apresentados na Figura 1.2. 

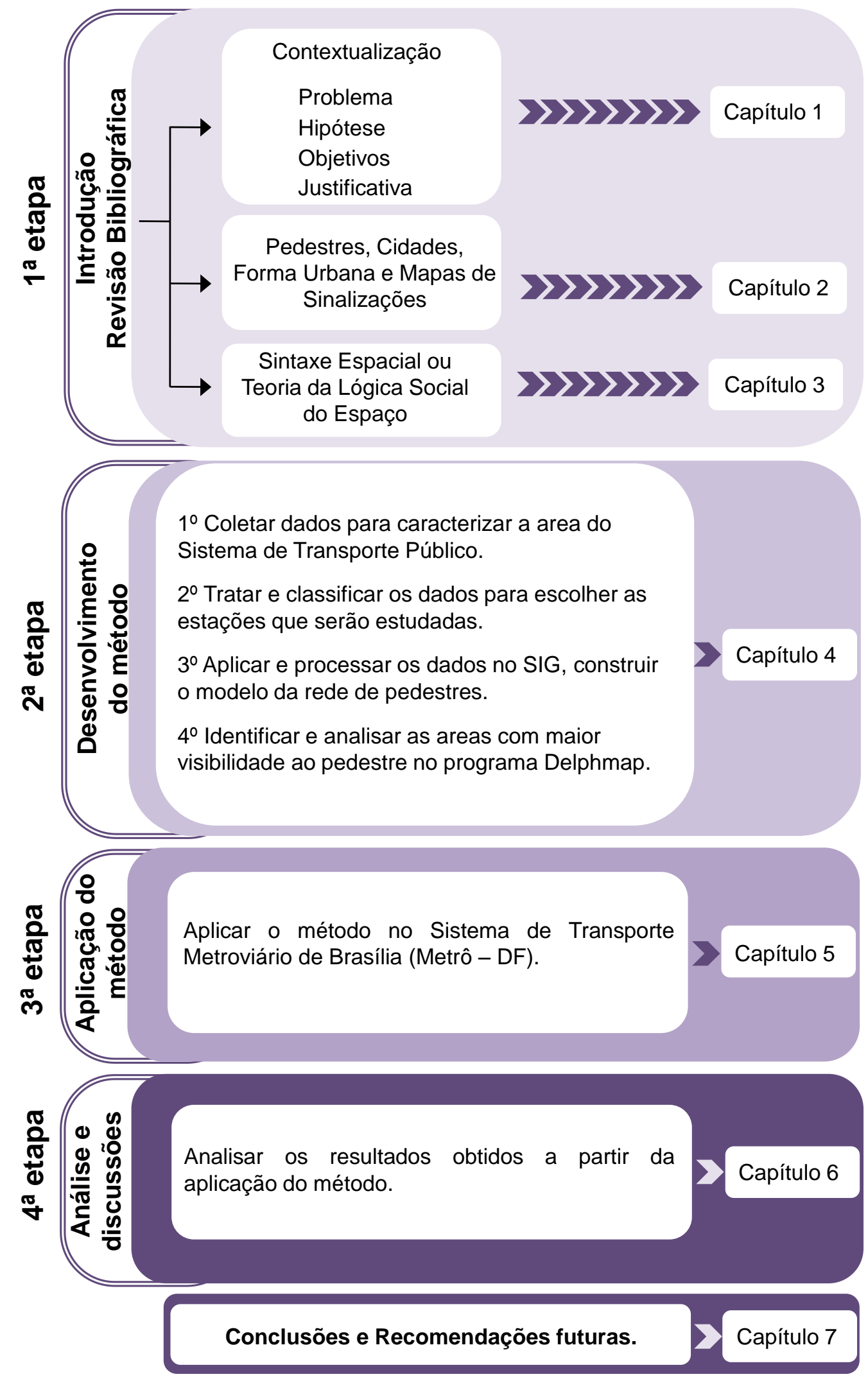

Figura 1.2 - Estrutura da Dissertação 


\section{PEDESTRES, CIDADES E FORMA URBANA}

\subsection{APRESENTAÇÃO}

Os capítulos 2 e 3 trazem os conceitos teóricos que respaldaram este estudo. Neste capítulo, são apresentadas algumas definições sobre pedestres e seus deslocamentos, em seguida a visão de três teóricos urbanos - Jane Jacobs, Kevin Lynch e Jan Gehl, que de forma conjunta demonstram a importância de manter vivo o espaço das cidades para o deslocamento de pedestres, e por último os conceitos de forma urbana e mapas de sinalizações para enfatizar a importância da leitura do espaço para o indivíduo.

\subsection{OS PEDESTRES}

Definir pedestre e identificar quais são as limitações a ele impostas quanto a sua locomoção, é de fundamental importância para entender porque os espaços públicos devem ser concebidos, primeiramente, em seu favor. Conforme a cartilla de peatones de Bogotá (2011), "pedestre é qualquer pessoa, com deficiências ou não, que está caminhando por uma via ou um terreno de uso público ou particular. Também se considera pedestre quem está empurrando um carrinho de bebê ou uma cadeira de rodas".

Para Eck (2004) a palavra pedestre significa uma condição temporária de um indivíduo e não uma determinada categoria da população. Melo et al., (2004) afirmam que "os pedestres formam um grupo heterogêneo de usuários do sistema viário, que engloba pessoas de diferentes faixas etárias, gêneros, nacionalidades e níveis socioeconômicos”. Este grupo se divide ainda em diferentes níveis de condições físicas de utilização do sistema viário, como exemplo, pessoas idosas e portadores de necessidades especiais. Silva e Lara (2005) definem pedestre como todo indivíduo que se desloca pelos espaços públicos abertos, independentemente das condições sensoriais e/ou motoras, do tempo de permanência, ou do modo de apropriação espacial.

Para este estudo será utilizada a definição de pedestre apresentada no panorama realizado por Fayumi (2011), em que os pedestres têm um conjunto de leituras possíveis, dentro dos seus perfis indicados, entretanto é de especial interesse as suas percepções de espaço e a maneira como se orientam espacialmente, caracterizando os fatores mais importantes na influência da caminhada, conforme apresenta a Figura 2.3. 
Para Beck (2011) a orientação espacial pode ser definida como a relação entre a posição momentânea do observador (pedestre) e as possíveis localizações de informações no espaço. Desta maneira, é possível concluir que a orientação espacial permitiria um deslocamento de forma mais rápida e segura para os pedestres. Por meio destas e outras definições o pedestre pode ser lido a partir de uma perspectiva de observador do espaço, buscando nele as informações necessárias para o seu deslocamento.

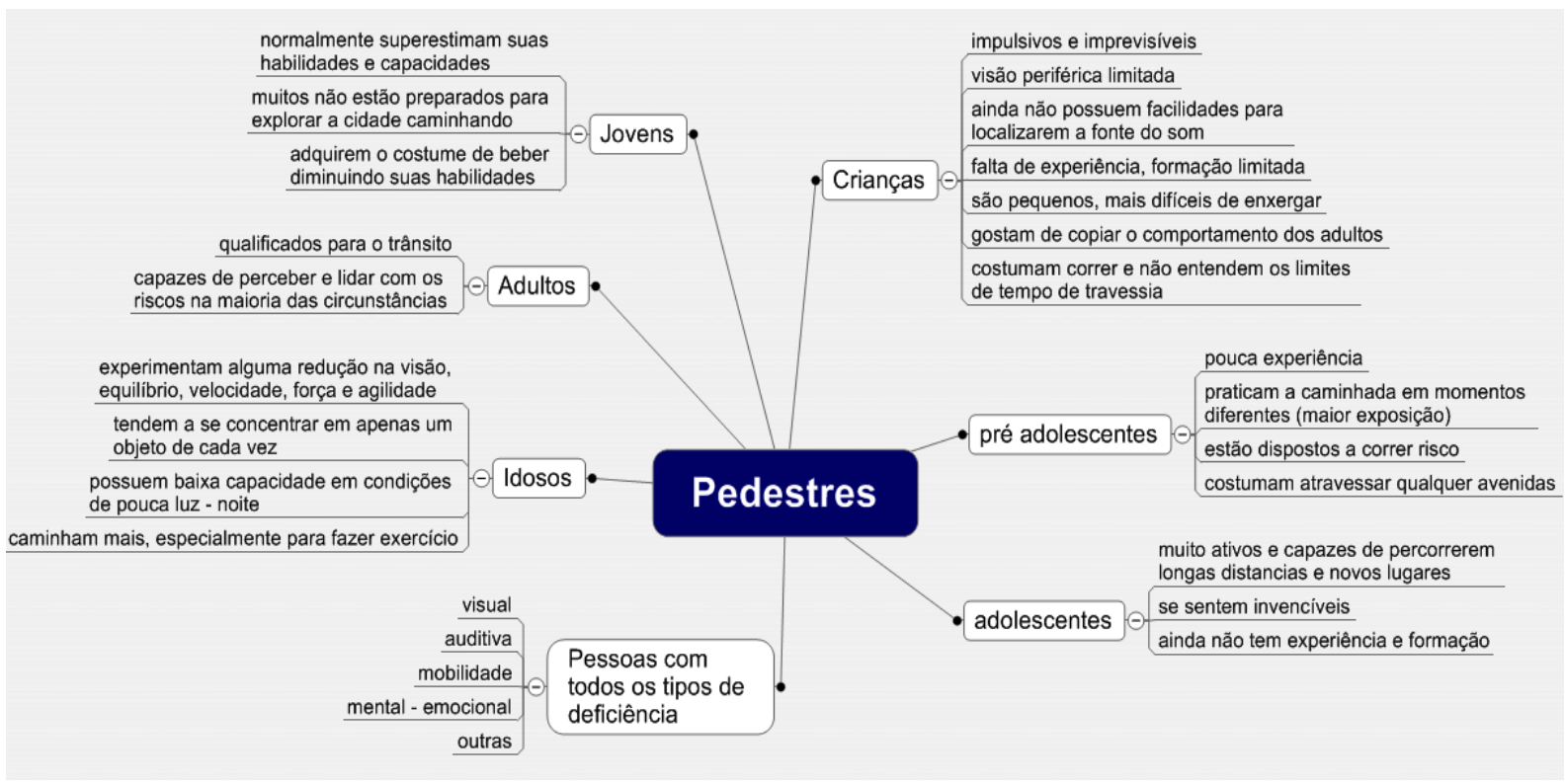

Figura 2.3 - Pedestres e suas características

Fonte: Fayumi (2011) com adaptações

\subsubsection{DESLOCAMENTO DE PEDESTRES}

Hillman (1994) afirma que não só andamos menos que nossos ancestrais, mas quase eliminamos a necessidade de caminhar, e que para muitas pessoas o caminhar é apenas uma maneira lenta e ineficiente de se aproximar daquilo que os olhos já viram. Porém essa visão não condiz com a importância que o deslocamento a pé tem nas relações dos indivíduos com a cidade, visto que além de ser um elo fundamental da circulação do qual todos os outros modos dependem, proporciona uma melhor qualidade de vida, não apenas por consumir energia própria, mas também pela inexistência de custo, menor poluição atmosférica e uma ínfima probabilidade de acidentes com outros pedestres.

O deslocamento a pé pode acontecer por motivos diversos, desde ir ao trabalho, escola, até para ter acesso a outras modalidades de transporte. Na Figura 2.4 foram elencados alguns dos motivos para o deslocamento acontecer. 


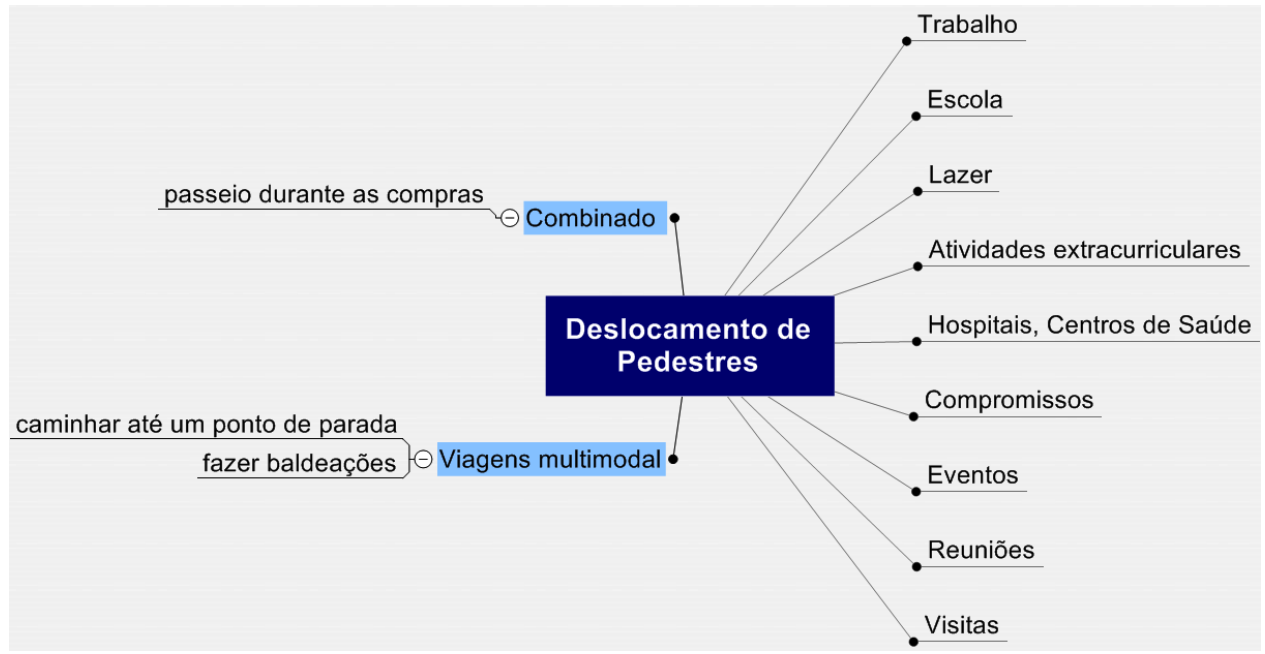

Figura 2.4 - Deslocamento de Pedestres

Por ser uma condição natural ao indivíduo, toda pessoa pratica a caminhada desde criança, porém o fomento do deslocamento a pé na cidade depende da criação de uma rede com itinerários atrativos, com sinalizações, mapas informativos e espaços adequados e próprios, cuja lógica pode ser a mesma adotada pelas áreas restritas ao tráfego de automóveis (Herce, 2009).

Fayumi (2011) apresenta, conforme mostra a Figura 2.5, alguns motivos que desestimulam as pessoas a caminharem, por exemplo, a falta de infraestrutura e o mau tempo. Porém o motivo de maior interesse para o presente estudo é o não fornecimento de recursos/informações de origem e destino, demonstrando assim o significativo papel que a informação exerce no estímulo ao deslocamento a pé. Cabe ressaltar que mesmo aqueles que conhecem a área ou região, como os moradores ou frequentadores assíduos da área, necessitam de informações de origem e destino, pois as informações reduzem as incertezas, gerando uma maior confiança e autonomia para os deslocamentos.

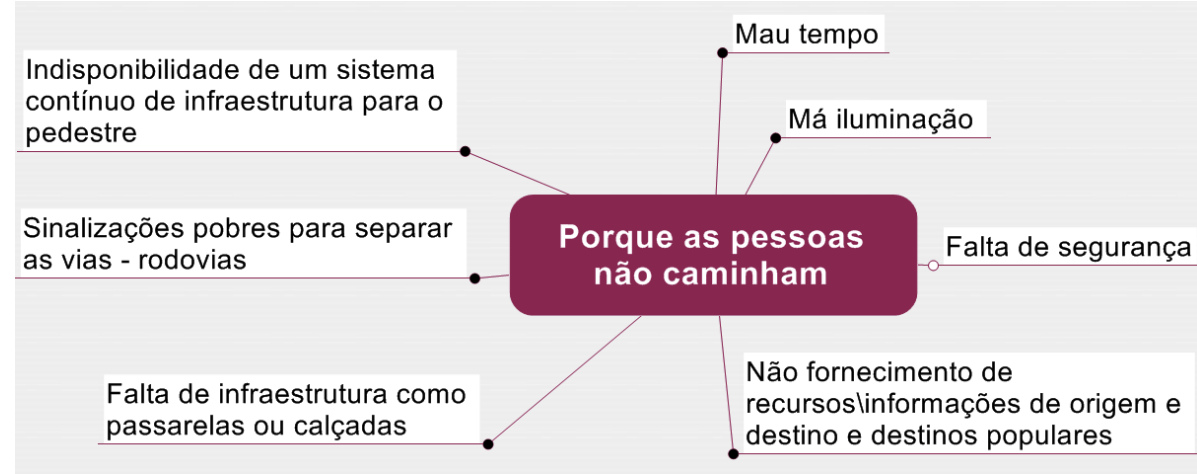

Figura 2.5 - Motivos para as pessoas não caminharem Fonte: Fayumi (2011) com adaptações 
No entanto, a vida na cidade inclui todas as diferentes atividades em que as pessoas se envolvem quando utilizam o espaço público e da mesma forma que existem motivos para não caminhar, existem motivos para que o indivíduo se sinta convidado para se deslocar a pé. Eck (2004) elencou quatro princípios chaves que atraem os pedestres para uma caminhada, conforme ilustrado na Figura 2.6. Como destaque, o princípio convite/motivação, que possui como atributo a localização dos lugares, reforça a importância da sinalização por meio de mapas, ícones informativos, totens, entre outros, que forneceria ao pedestre as informações necessárias de rotas, espaço e tempo de deslocamento, contribuindo para uma autonomia de escolha de rotas e lugares mais acessíveis.

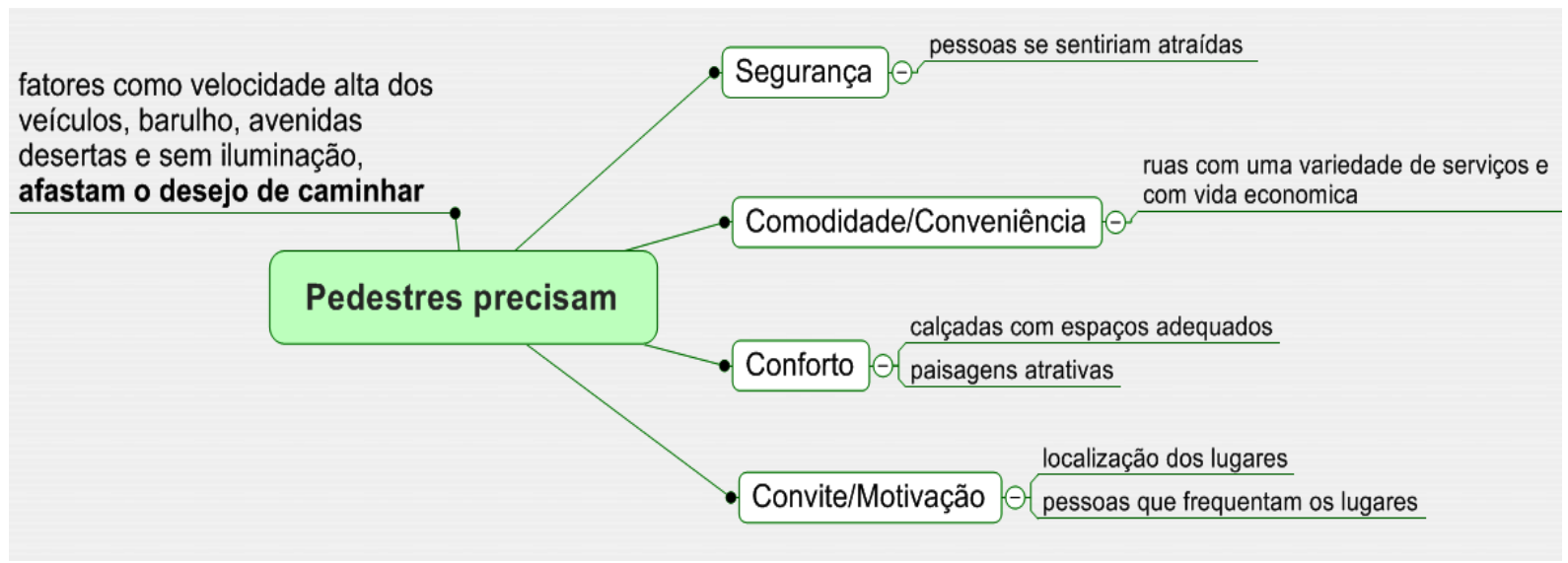

Figura 2.6 - Princípios chaves que atraem os pedestres

Fonte: Eck (2004) com adaptações

Em cidades vivas, seguras, sustentáveis e saudáveis, o pré-requisito para a existência da vida urbana, segundo Gehl (2013), é oferecer boas oportunidades para caminhar. Contudo, a perspectiva mais ampla é que uma infinidade de valiosas oportunidades sociais e recreativas apareça quando se reforça a vida a pé. $\mathrm{O}$ autor elenca três atividades básicas feitas pelos indivíduos, que são: sociais, necessárias e opcionais, conforme Figura 2.7. As três atividades podem ser realizadas por pessoas que moram na região, ou seja, conhecem a configuração do espaço, ou por pessoas que desconhecem por completo aquela área, e o deslocamento a pé pode ser escolhido para realizar qualquer uma delas. Porém cabe uma ressalva para as atividades opcionais por integrar diversão e lazer, ou seja, depende da qualidade das atrações fornecidas pela cidade, e isso engloba também o fornecimento de informações, não apenas em veículos de circulação popular (mídia), como as informações existentes nas cidades, em forma de mapas de sinalização, totens informativos, placas informativas, resultando em uma apropriação do espaço pelo indivíduo. 


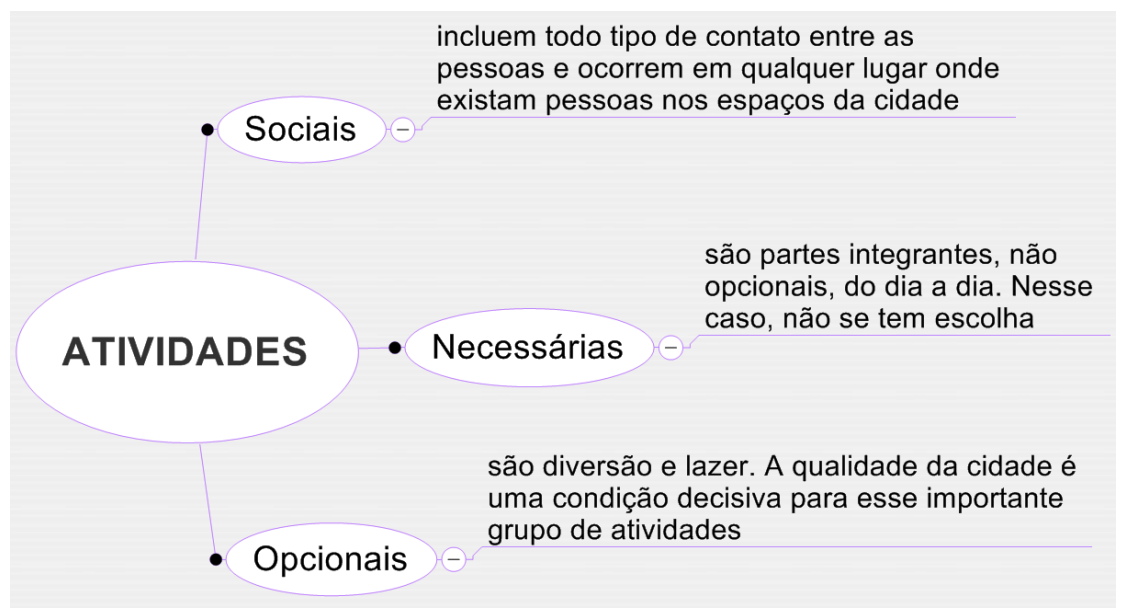

Figura 2.7 - Atividades sociais, necessárias e opcionais

Fonte: Gehl, 2013

A escolha do local da residência em relação à distância do local de trabalho ou estudo, por exemplo, é importante para tentar entender os fatores complexos que determinam a satisfação do deslocamento, pois estabelece o tempo de viagem, à distância, a inclinação do caminho, entre outras características. Entretanto, é possível inferir que quando uma pessoa escolhe, conscientemente, o deslocamento a pé para auxiliar a redução da poluição atmosférica, por exemplo, pode ser mais tolerante e mais propensa a uma longa caminhada para atingir o seu destino final. Da mesma forma que uma pessoa que caminha para cumprir um desejo de atividade física pode preferir uma rota com desníveis a uma rota totalmente plana.

A hipótese é que aqueles que valorizam a conveniência de sua localização em relação ao seu local de trabalho ou de estudo pode reagir de maneira diferente ao seu deslocamento do que alguém que escolhe a sua moradia distante do seu local de trabalho ou estudo, preferindo a tranquilidade de um lugar distante para morar. A Figura 2.8 mostra os tempos despendidos com alguns modos de transporte e suas potenciais formas de integração, conforme estudo realizado pela Transport of London (TfL) em 2007. O estudo revela que as pessoas, por desconhecerem as distâncias (tempo de caminhada) entre dois pontos do espaço no centro de Londres, escolhiam o modo metrô para se deslocarem em distâncias curtas. Com a descoberta dos estudos realizados pela Transport of London (TfL) desde 2004 e com a implementação de totens informativos de distância em tempo de caminhada, na região central de Londres em 2011/2012, as pessoas começaram a se deslocar a pé para curtas distâncias (até 15 minutos) com maior frequência. 


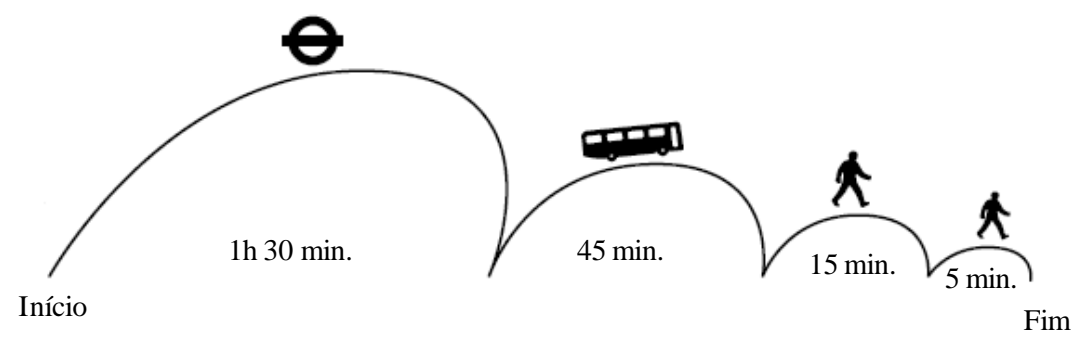

Figura 2.8 - Modos de deslocamentos

Fonte: Adaptado, Yellow Book Legible London, 2007

Observa-se que em todas as sociedades, mesmo as mais ricas, as pessoas caminham. Em cidades grandes, como São Paulo, 34\% dos deslocamentos diários são feitos exclusivamente a pé, sem contar com os percursos realizados para acesso a outro modo de transporte. A porcentagem de deslocamentos a pé realizados em grandes metrópoles dos países em desenvolvimento pode chegar a 39\% como em Jaipur (Índia). Já em Pequim (China), devido ao costume da utilização de bicicletas, a porcentagem é mais baixa, chegando a $14 \%$ conforme mostra a Figura 2.9 (Vasconcelos, 2012).

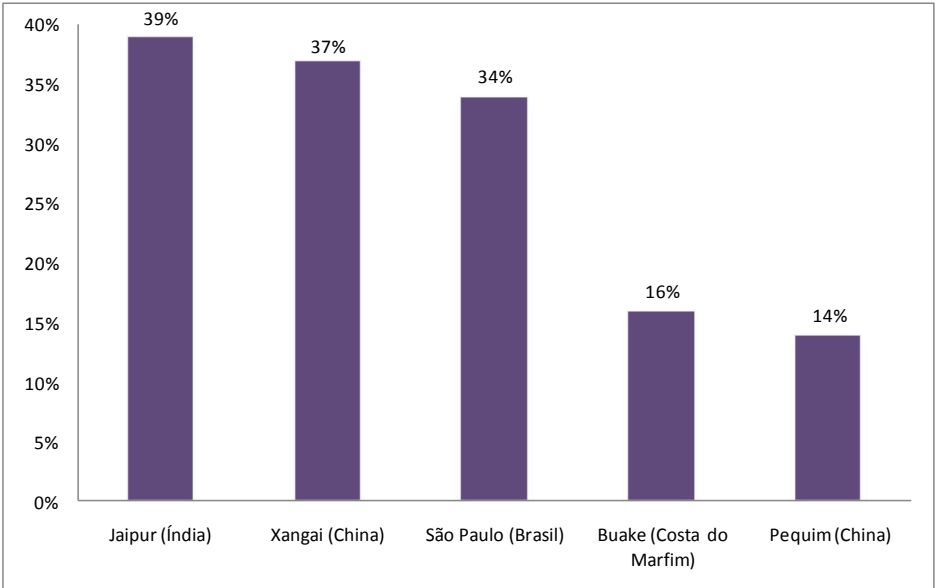

Figura 2.9 - Porcentagem de viagens a pé, em grandes cidades de países em desenvolvimento Fonte: Vasconcellos, 2012

No Brasil, a pesquisa CNI-Ibope (2011), exibiu que a porcentagem de deslocamentos a pé chega a $24 \%$ contra $39 \%$ das viagens realizadas por transporte público coletivo, sendo este o principal modo de deslocamento escolhido pela maioria da população brasileira. Contudo, nota-se que os modos não motorizados com $24 \%$ dos deslocamentos a pé e $8 \%$ por bicicleta, alcançam 30\% dessas escolhas em áreas urbanas, apontando uma segunda "preferência" dos deslocamentos feitos pelos brasileiros (Figura 2.10). 


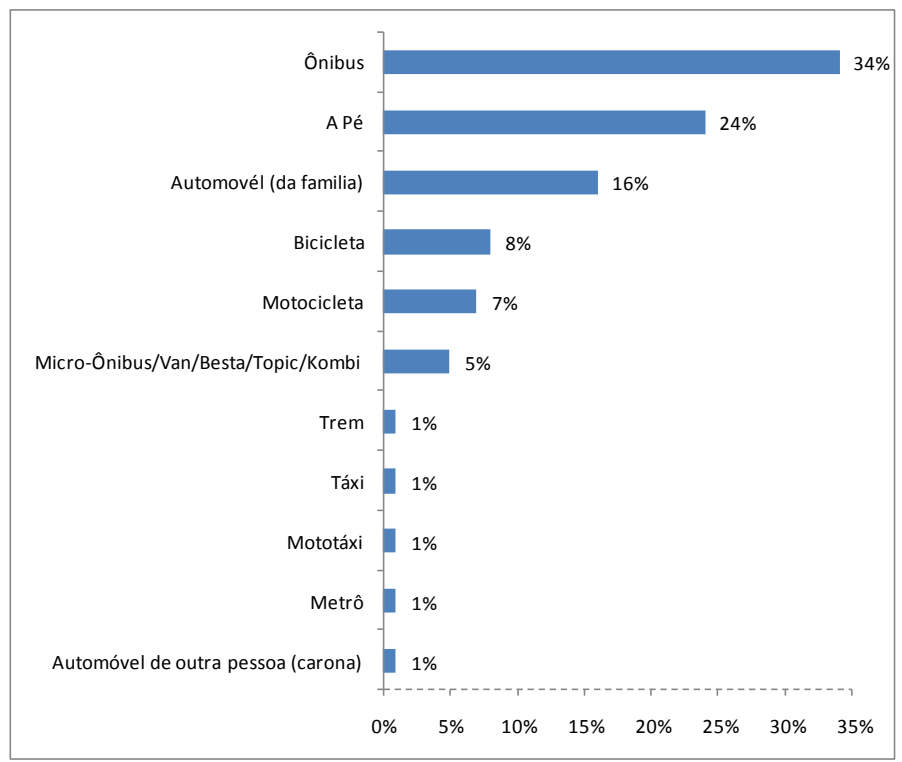

Figura 2.10 - Principal meio de transporte usado no deslocamento na cidade Fonte: Pesquisa CNI-Ibope, 2011

A partir das informações anteriores, é possível perceber que o deslocamento a pé é extremante utilizado, não só no Brasil, como em outros países. Infere-se ainda que o pedestre pode realizar diversas atividades demandando mais ou menos a sinalização, e para um deslocamento seguro e eficiente necessita de um conjunto de atributos que a cidade precisa oferecer. Desta forma, a configuração urbana da cidade tem papel fundamental na organização do espaço e acima de tudo na maneira pela qual os pedestres percebem o espaço e se deslocam nele.

Nesse contexto, a configuração urbana é entendida como a estrutura espacial das cidades e constitui o conjunto de barreiras e permeabilidades da estrutura física do espaço (Pereira et al., 2011).

De uma maneira mais geral a "estrutura espacial das cidades" é entendida sob o nome de "configuração urbana" e envolve o conjunto de relações entre o padrão de barreiras e de permeabilidades que constituem a própria estrutura física do espaço, onde a forma de disposição espacial relacional desses elementos pode proporcionar maiores ou menores facilidades (e restrições) para a sociedade desempenhar suas atividades no espaço, incluindo a circulação de pessoas. (Pereira et al., 2011:9) 


\subsection{CIDADES E PESSOAS}

Neste tópico, será abordado a produção dos autores Jane Jacobs (1916-2006), Kevin Lynch (1918-1984) e Jan Gehl (1936). Para os três autores, compreender a forma urbana é um viés necessário para interpretar e entender a dinâmica da cidade. Desta maneira, segundo esses estudiosos, será possível incentivar a utilização do espaço público e por consequência o conjunto de benefícios que o caminhar traz para a cidade e para os cidadãos.

Segundo Barros (2014) os três teóricos urbanos apresentam uma leitura diferenciada de forma urbana, demosntrando a importância de algumas variáveis para manter vivo o espaço das cidades, por meio do deslocamento de pedestres, recuperando dessa maneira a visão humanista da cidade.

Os contemporâneos Jane Jacobs e Kevin Lynch, na década de sessenta, apresentaram ao mundo a importância do planejamento das cidades para as pessoas, ou seja, como manter uma cidade viva, segura, miscigenada para as pessoas e não para edifícios ou veículos motorizados. Desta forma o tamanho de seus quarteirões, a mistura de usos, a não segregação de seus bairros, a legibilidade e a imagem da cidade utilizada por Lynch, vão ao encontro do que apresenta o arquiteto dinamarquês Jan Gehl, a partir da década de oitenta, quando afirma que a cidade precisa ser planejada em escala humana, ou seja, ao nível dos olhos.

A importância de se ter cidades para as pessoas desencadeia na compreensão da forma urbana, nas distâncias dos deslocamentos a pé, nas atividades desenvolvidas pelos indivíduos, etc., reforçando a necessidade de manter o indivíduo informado sobre seus tempos de percursos e rotas, culminando assim no foco desta pesquisa, qual seja a determinação de uma localização para disponibilizar unidades de informações espaciais aos pedestres.

\subsubsection{Jane Jacobs (1916-2006)}

Jane Butzner Jacobs, escritora norte-americana, publicou na década de sessenta: Morte e Vida de Grandes Cidades Americanas. Por meio das suas vivências e percepções, o livro traz informações profundas de sociologia, uma admirável pesquisa dos fatores que criam a vida e o espírito das cidades. 
Segundo Jacobs (2011), para compreender as cidades é primordial admitir que haja combinações ou misturas de usos e não a construção de usos segregados. Compreender que a mistura de usos é suficiente para promover a segurança urbana, pois o contato do público e a interação de usos precisam de uma quantidade significativa de componentes.

\footnotetext{
"Seja de que espécie for a diversidade gerada pelas cidades repousa no fato de que nelas muitas pessoas estão bastante próximas e elas manifestam os mais diferentes gostos, habilidades, necessidades, carência e obsessões.” (Jacobs, 2011:161).
}

A jornalista afirma que a paisagem urbana é viva graças à compilação de diversos tamanhos de elementos, sendo fundamental descobrir as situações e as razões econômicas que geram uma diversidade, ou seja, que permitem o seu surgimento. Portanto é importante compreender como as cidades podem conceber uma mistura suficiente de usos, uma diversidade suficiente, por uma tensão considerável de áreas urbanas para preservar a própria civilização.

Para a autora, a diversidade de elementos presentes nas ruas gera os atrativos para a miscigenação de pessoas e por consequência a utilização dos espaços públicos por todos. Para Jacobs existem quatro condições indispensáveis que geram uma diversidade pujante nas ruas e nos distritos:

\footnotetext{
"1- O distrito, e sem dúvida o maior número possível de segmentos que o compõem, deve atender a mais de uma função principal: de preferência, a mais de duas. Estas devem garantir a presença de pessoas que saiam de casa em horários diferentes e estejam nos lugares por motivos diferentes, mas sejam capazes de utilizar boa parte da infra-estrutura." (Jacobs, 2011:165).
}

As pessoas devem frequentar as ruas em horários diversificados e esta distribuição só é eficaz quando a mistura de pessoas na rua em determinado momento do dia é razoavelmente proporcional ao número de pessoas presentes em outros horários do dia, assim ocorrerá ao longo do dia, uma grande circulação, afirma a autora. Cabe avaliar que a presença de pessoas nas ruas, além de criar segurança na vizinhança, contribui para dar vida ao comércio local, pois as ruas e os estabelecimentos comerciais demandam frequentadores para criar e manter a diversidade viva na cidade. 
"2- A maioria das quadras deve ser curta; ou seja, as ruas e as oportunidades de virar esquinas devem ser frequentes." (Jacobs, 2011:165).

Jacobs declara que as ruas ajudam a gerar diversidade só pela maneira como atuam e que vizinhanças isoladas/separadas, têm tudo para serem abandonadas. Se houver predominância de quadras longas, por exemplo, mesmo as pessoas que moram ou circulam na vizinhança estarão tão afastadas que a formação de combinações razoavelmente complexas de usos urbanos compartilhados será impedida.

“3- O distrito deve ter uma combinação de edifícios com idades e estados de conservação variados, e incluir boa porcentagem de prédios antigos, de modo a gerar rendimento econômico variado. Essa mistura deve ser compacta." (Jacobs, 2011:165).

As cidades precisam intercalar prédios antigos para semear a diversidade. Elas precisam especificamente dos prédios antigos para incubar uma nova diversidade, assegura a autora. Ao falar de prédios antigos, a jornalista se refere a uma boa porção de prédios antigos simples, comuns, de baixo valor, incluindo alguns prédios antigos deteriorados, pois se uma área da cidade tiver apenas prédios novos, as empresas que venham a existir nesse local estarão limitadas, pois apenas existirão aquelas que podem arcar com os custos dos novos edifícios.

\footnotetext{
“4- Deve haver densidade suficientemente alta de pessoas, sejam quais forem seus propósitos. Isso inclui alta concentração de pessoas cujo propósito é morar lá.” (Jacobs, 2011:165).
}

Altas densidades habitacionais significam grande quantidade de moradias, porém isso não está relacionado com superlotação, isto é, muitas pessoas numa moradia em relação ao número de cômodos que ela possui, é diferente do número de moradias na área.

Em resumo, as cidades precisam de todos os tipos de diversidade e a maior parte da diversidade urbana é criação da pluralidade de pessoas, com concepções, organizações e propósitos bastante distintos. Isso é necessário para que a vida urbana funcione adequadamente, de modo que a população das cidades possa se preservar e se desenvolver. Os bairros, os quarteirões não podem ser grandes, nem afastados, isso prejudica a mistura de pessoas e logo não se torna um atrativo para a prática da caminhada. 


\subsubsection{Kevin Lynch (1918-1984)}

O urbanista e escritor norte americano Kevin Andrew Lynch, publicou livros que retratavam a história no ambiente urbano, ou seja, como os ambientes urbanos podem afetar as vidas das pessoas, em relação à percepção da cidade e suas formas físicas (desenho urbano). O seu livro mais famoso - A imagem da Cidade (1960) - mostra que a cidade (obra arquitetônica) é uma construção em grande escala no espaço, tendo o design como uma arte temporal, sendo percebido no decorrer dos longos períodos de tempo. Lynch traz nesta obra que nada é vivenciado em si mesmo, mas sempre em relação aos seus arredores, às sequências de elementos, à lembrança de experiências passadas. A cidade não é apenas um objeto percebido, ela pode ser estável por algum tempo, mas está sempre se modificando nos detalhes e cada pessoa possui associações com alguma parte de sua cidade.

"A Imagem da Cidade" examina a qualidade visual de três cidades norte americanas: Boston, Jersey City e Los Angeles, focando nas qualidades visuais específicas de clareza e de legibilidade. Ao comparar essas três cidades, Kevin Lynch conclui que as pessoas se adaptam ao seu entorno e extraem estrutura e identidade do material ao seu alcance.

O autor afirma que a legibilidade abarca uma importância especial, quando os ambientes são considerados em escala urbana de dimensão, tempo e complexidade, mesmo que a legibilidade não seja o único atributo importante de uma bela cidade. É preciso levar em consideração a cidade do modo como seus habitantes a percebem. A descrição mental de cada pessoa sobre o mundo físico exterior é o nexo estratégico da imagem ambiental no processo de orientação. $\mathrm{O}$ indivíduo possui necessidade de reconhecer e padronizar ambientes desde os tempos arcaicos, pois o reconhecimento da imagem, ou seja, a orientação é de enorme importância prática e emocional de um indivíduo (Lynch, 2011).

Uma imagem clara permite uma locomoção mais rápida e fácil, porém um ambiente ordenado pode fazer mais do que isso e servir de referência para encontrar a casa de um amigo, por exemplo. Uma imagem clara do entorno constitui um alicerce oportuno para o desenvolvimento individual. $\mathrm{O}$ indivíduo com uma boa imagem ambiental possui um sentimento de segurança emocional, podendo estabelecer uma relação harmoniosa entre o mundo à sua volta, assegura Lynch (2011). A propósito, como o objetivo geral deste estudo é 
encontrar os locais apropriados para disponibilizar unidades de informações espaciais, no intuito de promover um melhor deslocamento do pedestre em áreas próximas as estações de transporte público, um ambiente caracterizado e legível não concede apenas segurança, mas também reforça a profundidade e a intensidade da experiência humana, pois a cidade é em si um símbolo poderoso de uma sociedade complexa.

Uma imagem ambiental pode ser decomposta em três componentes: identidade, estrutura e significado. As imagens ambientais são fruto de um processo mútuo entre o observador com grande capacidade de adaptação e à concepção de seus próprios objetivos - seleciona, organiza e confere significados àquilo que vê em seu ambiente com peculiaridades e relações. Cada indivíduo cria e assume sua própria imagem, mas parece existir um consentimento precípuo entre membros do mesmo grupo. Essas imagens de grupo, consensuais a um número significativo de observadores, é que interessam aos planejadores urbanos empenhados à concepção de um ambiente que será utilizado por muitas pessoas, consolida Lynch (2011).

Para o arquiteto, uma imagem viável exige, em primeiro lugar, a identificação de um objeto, o que implica sua personalização. Em segundo lugar, a imagem deve incluir a relação espacial do objeto com o observador e os outros objetos, e, por último, esse objeto deve ter algum significado para o observador, seja ele prático ou emocional. Para adquirir valor em termos de orientação no espaço ocupado pelas pessoas, uma imagem precisa ter diversas qualidades. Deve ser suficiente, verdadeira em sentido pragmático, permitindo que o indivíduo atue dentro do seu ambiente na medida de suas necessidades.

Paralelamente, um ambiente para ser bonito dispõe de originalidades básicas como: significado ou expressividade, prazer sensorial, ritmo, estímulo, escolha. O objetivo de Lynch no livro consiste apenas em instigar a necessidade de identidade e estrutura no mundo perceptivo, e enfatizar a relevância especial dessa qualidade para o caso específico do complexo e mutável espaço urbano.

O conteúdo das cidades estudadas, no livro de Lynch (2011), remete às formas físicas que são classificadas em cinco tipos de elementos: vias, limites, bairros, pontos nodais e marcos. Uma cidade é uma organização mutável e polivalente, um espaço com muitas funções, construído por muitas mãos num período de tempo relativamente rápido. Contudo existem algumas 
funções basilares, que as cidades expressam por suas formas como: a circulação, os principais usos do espaço urbano, pontos focais chaves, entre outros.

Em resumo, a cidade não é designada apenas para uma pessoa e sim para um grande número delas. O urbanista deve, portanto, criar uma cidade que seja generosa em vias, limites, marcos, pontos nodais e bairros, uma cidade que use não apenas uma ou duas qualidades, mas todas elas. Estruturalmente as cidades possuem os marcos ou pontos nodais, e é exatamente neles que os elementos de referência (mapas de sinalizações, totens, etc.), caso existissem, contribuiriam para uma melhor orientação espacial, pois seriam locais adequados para uma sinalização com maior abrangência para os pedestres.

\subsubsection{Jan Gehl (1936)}

Jan Gehl é arquiteto e urbanista dinamarquês, focou sua carreira na melhoria da qualidade de vida urbana por meio da reorientação do desenho da cidade para pedestres e ciclistas. Um dos objetivos de sua carreira é promover a qualidade dos espaços urbanos, de modo a fomentar o uso destes tanto em termos de deslocamento, quanto de interação. Publicou diversos livros, sendo o mais conhecido o intitulado de Cidades para Pessoas (2013), demonstrando de forma empírica suas ideias para melhorar os espaços públicos urbanos.

A visão humanista do autor foi interpretada pelos modernistas da década de 50 e 60 como uma espécie de retrocesso, em que o crescimento de uma cidade se materializava criando ambientes impregnados de contaminação ambiental e insegurança, deixando longe a condição habitável das pessoas. Porém suas propostas não são um retrocesso, estão destinadas a desenvolver uma fórmula para que as cidades sejam mais seguras e sustentáveis. Estas propostas possuem a premissa de humanizar os espaços, isto é, fechar espaços de tráfego, comprovando que as pessoas são capazes de se adaptar as rotas alternativas de circulação.

$\mathrm{O}$ arquiteto acredita que as cidades podem ter um bom desempenho e entende que o planejamento urbano envolve três níveis de escala: a grande escala, correspondente ao projeto concebido desde uma perspectiva aérea macro (global); a média escala, correspondente ao projeto de bairros ou áreas determinadas da cidade, ainda com a perspectiva aérea, embora em baixa altitude; e principalmente na pequena escala que é "a cidade experimentada pelas pessoas que a utilizam ao nível dos olhos". Gehl acredita que a macro escala é um problema e o intitulou como a "Síndrome de Brasília", porque Brasília foi planejada tendo a escala macro 
como prioridade e faltou atenção para a escala humana. $\mathrm{O}$ importante não é diferenciar um edifício observado do céu, e sim projetar uma cidade desde a rua para que haja humanização dos espaços, afirma o autor.

\footnotetext{
"Vista do alto, Brasília é uma bela composição, mas a cidade é uma catástrofe ao nível dos olhos. Os espaços urbanos são muito grandes e amorfos, as ruas muito largas, e as calçadas e passagens muito longas e retas". (Gehl, 2013:196-7)
}

Para uma melhor dinâmica nas cidades, Gehl (2013) evidência cinco características fundamentais: a condensação da estrutura urbana; uma presença suficiente de moradias, inclusive nos centros, ou seja, uma densidade populacional razoável; a promoção de distâncias admissíveis para os pedestres e bicicletas, acentuando as trocas interpessoais; a presença de diversidade de funções; e a promoção de espaços com atenção ao nível dos olhos.

A distância, para Gehl (2013), desempenha um papel determinante na interação pessoal, por isso é de extrema importância projetar em escala humana. Ele afirma que de 300 a 500 metros, os seres humanos podem identificar outras pessoas como seres humanos, em vez de objetos. De 25 a 100 metros, as características individuais e a linguagem corporal podem ser observadas e a menos de 25 metros, as pessoas entram em um campo "social" da visão onde a riqueza de detalhes e a comunicação podem se intensificar metro a metro.

Em resumo, o autor, um grande crítico do urbanismo modernista, defende a ideologia do planejamento com a dimensão humana. $\mathrm{O}$ arquiteto parte do pressuposto de que o ser humano é um ser social, e que o maior dos problemas da atualidade é a deterioração da qualidade dos espaços públicos. Também argumenta que a ideologia funcionalista e rodoviarista do modernismo privilegiou os carros ante as pessoas, os edifícios em lugar do espaço público, o planejamento "visto da janela de um avião" ao invés de pensá-lo a partir do nível dos olhos. O arquiteto afirmou em entrevista à revista Arquitetura e Urbanismo (edição 215): "Nos tempos antigos, sempre se pensou nessa ordem: pessoas, espaços e edifícios. Até que se inverteu a ordem: edifício, espaços e pessoas".

Planejar as cidades para pessoas significa produzir para os indivíduos infraestrutura para que eles possam usufruir dos espaços públicos da maneira mais rápida e simples possível, ou seja, os modos não motorizados de deslocamentos são os norteadores para uma escala mais 
humanizada. As pessoas para se sentirem seguras necessitam conhecer os espaços, saber como podem chegar com rapidez e segurança aos seus destinos e isso implica a disponibilização de informações espaciais. Planejar na escala humana também significa produzir informações mais aprimoradas dos espaços públicos, com detalhes de rotas, distância, tempo de caminhada, destinos mais procurados, entre outros, ou seja, a compreensão da forma urbana é de vital importância para a apropriação dos espaços pelos indivíduos.

\subsection{FORMA URBANA E MAPAS DE SINALIZAÇÕES}

Neste tópico, apresentam-se os conceitos de forma urbana e mapas de sinalizações. Sendo a cidade feita por relações, é possível estabelecer quais são os pontos de convergência, isto é, pontos que merecem uma maior atenção, no conjunto de tratamentos inclusive de condução dos indivíduos. Barros (2014) afirma que é fundamental uma perspectiva relacional que integre um conjunto de princípios de modo que o arranjo entre os elementos componentes de uma cidade possa ser qualificado como fator que afeta o caminhar e o pedestre.

\subsubsection{Forma urbana}

A forma urbana é extremante importante para o desenvolvimento e a qualidade de vida das pessoas. Os desenhos modernistas das cidades privilegiaram os modos motorizados, e, em particular, o automóvel, num modelo que se autoalimenta. Diante disso, os pedestres sofrem com a falta de representações dos espaços, ou seja, elementos que possam ajudá-lo a decodificar e compreender os quarteirões, os bairros, as ruas das cidades. Compreender a forma urbana é se apropriar dos espaços, pois as cidades são constituídas por relações, por pontos convergentes e atratores de atividades.

Lamas (2004) diz que um primeiro grau de leitura da cidade é eminentemente físico-espacial e morfológico, portanto o único que permite evidenciar a diferença entre este e outro espaço, entre esta e aquela forma, é explicar as características de cada parte da cidade.

Barros (2014) relata que o ato de caminhar favorece uma coerente apreensão e vivência da cidade, por razões sedimentadas em distintos campos disciplinares. A autora infere que há uma lógica na organização dos espaços urbanos que afeta o processo de escolha dos caminhos, o que expressa à preferência dos indivíduos por um percurso ou outro. Hiller 
(2008) interpreta o andar na cidade segundo a capacidade dos lugares serem rotas ou pontos de chegada, ou seja, as origens e os destinos.

O conceito de forma urbana adotado por Barros (2014) será utilizado para este estudo, em que os elementos presentes na cidade em relação às suas dimensões e proporções: ruas, edifícios, quarteirões, fachadas, mobiliário urbano, vegetação, etc. formam a composição geométrica da cidade e que, além disso, é necessário explorar como os elementos que integram o espaço urbano estão dispostos e relacionados, seja em perspectiva bi ou tridimensional.

É quase improvável ter nos dias de hoje um desenho homogêneo que se distribua por toda a cidade, pois as cidades não são constituídas de malhas rígidas, mas sim pela mistura entre os extremos de regularidade e de irregularidade, na visão de Kostof (2001). Medeiros (2013) também ressalta as regularidades e irregularidades das cidades ao comparar uma série de cidades pelo mundo, porém destacando que a questão não é a existência de um tipo ou outro, e sim como as articulações na cidade ocorrem.

Cabe destacar a diferença conceitual feita por Barros (2014) de forma urbana para a arquitetura que prioriza os aspectos de composição e relações entrepartes e para a engenharia de transportes que interessa aspectos de infraestrutura de transportes urbanos. Rodrigue (2006) traz que a demanda e a capacidade de transporte (infraestrutura) formaram a escala urbana, pois o crescimento demográfico demanda maior mobilidade, sejam nos sistemas de transportes públicos, no sistema viário, nos bairros, nas ruas ou calçadas.

\footnotetext{
“Consequentemente, há uma grande variedade de formas urbanas, estruturas espaciais e sistemas de transportes urbanos associados. Forma urbana se refere à impressão espacial de um sistema de transporte urbano bem como das infraestruturas físicas adjacentes. Em conjunto, eles conferem o nível de organização espacial para as cidades (Rodrigue, 2006:171)".
}

Barros (2014) acredita que compreender a forma urbana admite entender concomitantemente os aspectos geométricos e topológicos, com foco nas relações, pois o desenho da malha viária ou as distâncias suscetíveis para o deslocamento, por meio de qualquer modo de transporte, fazem parte das articulações dos elementos constituintes da cidade. Vale ressaltar que para este estudo, assim como adotado por Barros (2014), topologia é considera como o estudo de 
relações espaciais que independem de forma e tamanho, já geometria é a descrição direta dos elementos físicos componentes quanto às dimensões, proporções, escalas, entre outros.

Como a forma urbana das cidades afeta diretamente a maneira como os indivíduos leem os espaços, é possível descrevê-la por meio de mapas, pois é por meio da visão que se constrói a parte mais importante da imagem de uma cidade, e as unidades de informações (mapas) poderiam ser de grande valia para deslocamentos mais seguros e precisos.

Dependendo de como for constituída a cidade, ou seja, a estrutura de seus quarteirões, bairros, ruas, etc., os indivíduos necessitarão de mais mapas e sinalizações para decodificarem os espaços. Diante desta necessidade, a sintaxe espacial apresenta-se como uma estratégia de decodificação do processo de percepção do espaço a partir da utilização das Isovistas.

\subsubsection{Mapas de Sinalizações}

Um mapa é uma simplificação do mundo real, consiste em uma representação da paisagem por meio de símbolos, cores, traços e sinais, alocados em locais específicos e devem ser facilmente interpretados pelos usuários. Conforme Correia e Martins (2008) mapa é a representação no plano, normalmente em escala pequena $(<1: 1.000 .000)$, dos aspectos geográficos, naturais, culturais e artificiais de uma região da superfície terrestre, delimitada por elementos físicos, político-administrativos, destinada aos mais variados usos temáticos, culturais e ilustrativos.

Silva et al., (2012) afirmam que os mapas além dos aspectos puramente técnicos, que envolvem geodesia, projeções cartográficas e procedimentos de medições de campo, precisam também utilizar símbolos que possam ser interpretados por todos. Os sinais como forma de comunicação nos mapas devem satisfazer exigências como: ser relevante para o leitor, ser facilmente entendido, identificado e lido (NZ Transport Agency, 2008).

Orientação, no sentido geográfico, é o mesmo que caminho ou sentido. A noção de espaço é suporte para qualquer estudo geográfico: não há geografia sem espaço, assim como não há escala sem espaço. Saber se orientar é buscar se localizar no espaço/ambiente. Lesann (2007) afirma que a noção de localização antecede a de espaço e que localização é o conjunto das características de um ponto preciso no espaço. 
O orientar-se de uma pessoa no aspecto geográfico quer dizer: ter conhecimento de onde está e para qual o sentido de movimentação ela pode seguir. A maneira mais conhecida de se orientar é por meio de instrumentos como as bússolas ou os mapas. Em locais totalmente desconhecidos, o auxílio e a utilização de um mapa é feito em praticamente todos os casos. Porém, antes de um mapa ser utilizado ele precisa ser "orientado", ou seja, ser ajustado conforme a posição da pessoa no terreno, de modo que as direções no mapa coincidam com as direções no terreno.

A população, em sua grande maioria, não tem o costume ou treinamento de utilizar instrumentos de orientação espacial como os engenheiros, arquitetos ou militares que são especialistas em medidas de direção, cálculos, etc., e muitas vezes não podem facilmente identificar posições em um mapa e calcular direções.

Estudos acadêmicos (Abreu, 2004; Silva, 2007) apontam que no Brasil, há uma deficiência no ensino de tópicos cartográficos e que os alunos raramente trabalham com mapas em escalas grandes, como 1:1000 a 1:10000, as quais são as medidas usadas em mapas de cidades e mapas de sinalizações.

Entretanto, os mapas são extremamente importantes para o deslocamento eficaz de um pedestre que desconhece a cidade por onde pretende caminhar. Por representarem a realidade de maneira simplificada, os mapas podem também conter informações de destinos mais frequentados, rotas mais utilizadas e seguras, distância em quilômetros, etc., são os famosos mapas de sinalizações.

Os mapas de sinalização normalmente são mapas fixos colocados em painéis ou paredes. Quando estão destinados aos passageiros ou pedestres, frequentemente são localizados em túneis, estações de metrô, paradas de ônibus, nos portos e aeroportos. Também são encontrados como informações de evacuação de emergência em hotéis, prédios comerciais de grande circulação e normalmente estão fixados próximos de escadas, elevadores, etc.

Os mapas de sinalização expõem, em sua maioria, o local onde o usuário/pedestre se encontra com precisão, usando a tradicional frase "você está aqui". Os mapas além de mostrarem a localização do indivíduo, eles também precisam exibir as imediações e, de preferência, por 
qual direção seguir, principalmente se forem utilizados nos casos de evacuação de emergência. É extremamente importante que os mapas tenham boa qualidade gráfica e sigam a visualização cartográfica comum.

De acordo com o Transport for London (TfL, 2013) um mapa de sinalização precisa apresentar quatro requisitos básicos:

i) Identificar as rotas dos pedestres - analisar os movimentos dos pedestres nas rotas e as suas linhas de desejos;

ii) Pontos de tomada de decisão de um pedestre - identificar os principais pontos/lugares onde os pedestres param para tomarem decisões de rotas;

iii) Origem - identificar todos os locais de origem da área; e

iv) Destinos - identificar todos os locais de destino da área.

Para aumentar o valor dos sinais, o estudo apresentado pelo TfL (2013) confirmou que um sistema de sinalização precisa oferecer previsibilidade, consistência e respeitabilidade. Um Mapa de sinalização (direção e tempo) tem muitas vantagens sobre um texto em termos de quantidades e clareza das informações. Mapas também apoiam uma comunidade diversificada onde a linguagem ou habilidades de leitura pode apresentar uma barreira para as pessoas.

A Figura 2.11 traz um exemplo de um mapa de sinalização disponibilizado em diversos pontos na cidade de Londres (Inglaterra).

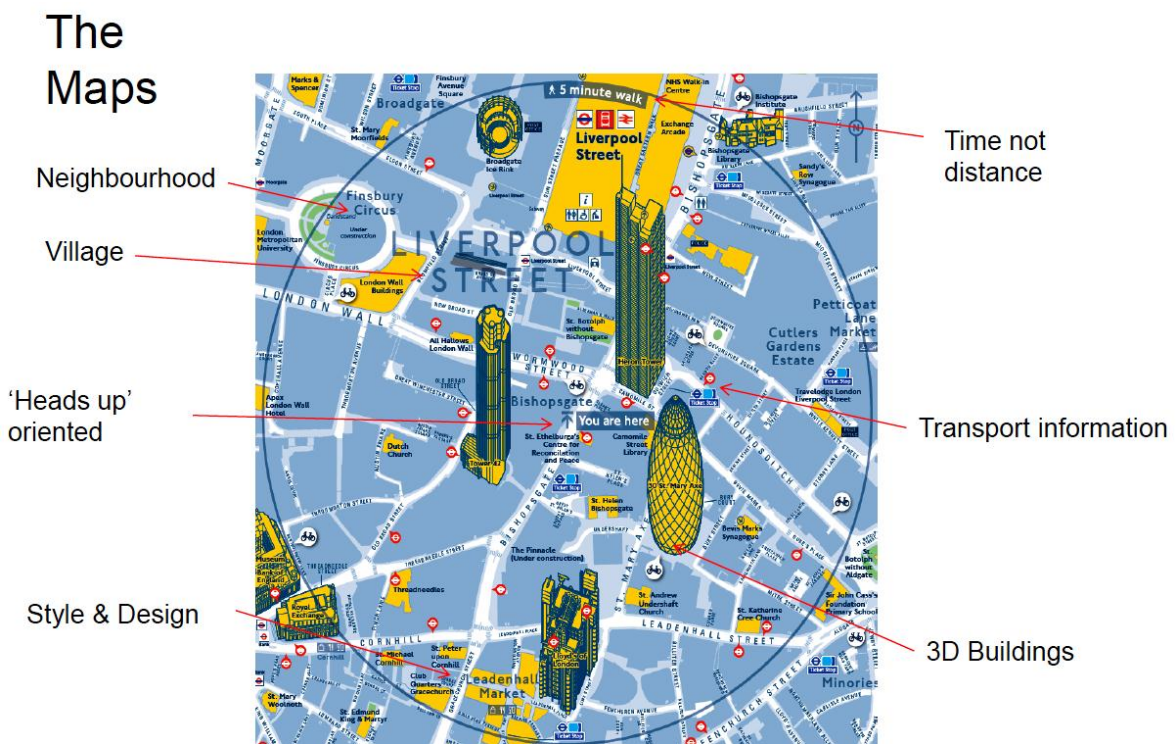

Figura 2.11 - Exemplo de um Mapa de Sinalização

Fonte: Wayfinding and walking in London, (TfL, 2013) 
A importância de um mapa de sinalização é grande no reconhecimento da cidade, permitindo que um indivíduo possa se orientar em determinadas áreas e espaços públicos, embora ainda no Brasil, os mapas de sinalização não conseguiram ter tanta relevância para os órgãos competentes de urbanização. Cabe frisar que toda ação de humanização da paisagem contém objetivos e valores estéticos que se comunicam por meio dos sentidos ou da percepção. Em resumo os valores estéticos só são comunicáveis por meio dos sentidos e apesar de as características da forma não sintetizarem os aspectos sensoriais, estes são determinantes na sua compreensão.

É importante lembrar também que os mapas precisam ter uma quantidade e uma localização certa, com uma sinalização padronizada, uma vez que em excesso podem poluir o ambiente e confundir o pedestre/usuário ao invés de auxiliá-lo.

\subsection{TÓPICOS CONCLUSIVOS}

As cidades são compostas por barreiras e permeabilidades, e o manejo da forma urbana afeta o campo de visão dos indivíduos, ou seja, a maneira como a cidade é representada por meio de elementos decodificadores do espaço entra como uma estratégia para facilitar o processo de percepção e no segundo nível de sinalização para o indivíduo/pedestre, pois a visibilidade influência criticamente os padrões de escolha de percursos e interação com os objetos presentes.

Os três teóricos urbanos são autores que quebram o conceito usual de cidade moderna, assumindo que as cidades modernas precisam ser revistas, pois trazem sem suas configurações uma maneira de articulação que compromete um conjunto de percepções de seus usuários.

As cidades em sua perspectiva de leitura do espaço e deslocamento precisam ser pensadas e planejadas para os pedestres utilizando ferramentas e instrumentos capazes de identificar os fatores e elementos necessários para a um deslocamento contínuo que proporcione uma apropriação do espaço pelos indivíduos. 


\section{FERRAMENTA PARA IDENTIFICAÇÃO DE CARACTERÍSTICAS ESPACIAIS RELEVANTES AO DESLOCAMENTO DE PEDESTRES: SINTAXE ESPACIAL - ISOVISTAS}

\subsection{APRESENTAÇÃO}

Neste capítulo são apresentados os conceitos teóricos da Teoria da Lógica Social do Espaço ou Sintaxe Espacial, e das Isovistas que formam uma ferramenta na identificação de características espaciais relevantes ao comportamento humano. Explica-se a Teoria da Lógica Social do Espaço, ou Sintaxe Espacial, em aspectos teóricos, metodológicos e ferramentais, no qual este último possibilita o enquadramento, por meio das Isovistas, do fornecimento de visibilidade aos pedestres em seus deslocamentos. As cidades, a configuração dos seus espaços e as relações sociais que as envolvem são fontes de pesquisas da Sintaxe Espacial.

\subsection{A TEORIA}

A Sintaxe Espacial ou Teoria da Lógica Social do Espaço foi desenvolvida na University College London (UCL), por Hillier e colaboradores na década de 1970. A teoria originou-se a partir da observação da cidade e da integração dos aspectos físicos com todas as interações sociais, abordando e considerando as relações do espaço com outras relações do sistema determinante nos movimentos urbanos.

A criação da teoria, "amparada pelos pensamentos sistêmico e estruturalista, deriva da preocupação de que as teorias (em arquitetura) têm sido extremamente normativas e pouco analíticas" (Medeiros, 2013; Hillier e Hanson, 1997). A proposta é que no lugar de tentar encaixar, a qualquer custo, uma fórmula em edifícios e cidades, é necessário estudar o fenômeno à exaustão e procurar encontrar propriedades gerais dos esquemas relacionais a ele (Medeiros, 2013).

Medeiros (2013) descreve a teoria da seguinte maneira:

“A abordagem contempla técnicas de entendimento e representação do espaço, gera subsídios que permitem ao pesquisador investigá-lo do ponto de vista das articulações urbanas, descreve possibilidades de interação e contatos a partir de possíveis fluxos diferenciados de pessoas ou veículos. Equivale à exploração dos espaços deixados pelos cheios ou vazios na cidade ou no edifício, facilmente ilustrado por um mapa de figurafundo". (Medeiros, 2013:139-140). 
Sintaxe espacial é um conjunto de técnicas para a análise de configurações espaciais utilizando gráficos simples, constituído unicamente por caminhos e nós. As técnicas foram desenvolvidas a fim de analisar as interrelações entre as estruturas espaciais e sociais. Esta redução do espaço analítico para uma informação topológica matemática facilita o cálculo dos valores característicos e a comparação quantitativa dos ambientes.

De acordo com Raford et al., (2007), a Sintaxe Espacial é um conjunto de técnicas usadas para medir os efeitos da estrutura urbana e a rede viária sobre a acessibilidade e o movimento. Porém a Sintaxe Espacial não é apenas um conjunto de técnicas, mas sim uma teoria, cujo método implica em um conjunto de técnicas para as análises configuracionais. A análise configuracional é uma descrição da organização espacial com base em sistemas de relações de propriedades estruturantes, na qual se observa os padrões de uso do comportamento espacial.

Hiller (2005) mostra que "historicamente, o objetivo da Sintaxe Espacial foi construir a ponte entre a cidade humana e a cidade física". Holanda (2001) diz que "é uma teoria que se localiza no âmbito dos estudos que relacionam espaço e comportamento, mas as dimensões de um e de outro são precisamente delimitadas".

Segundo Barros (2006), por meio de um método e de suas técnicas, a Teoria da Sintaxe Espacial é capaz de estabelecer relação entre categorias no âmbito sintático - função do espaço - no qual o observador é capaz de interpretar os espaços das cidades a partir das feições urbanas e, no âmbito semântico - significado do espaço - buscando conhecer a ocorrência da relação entre grupos e indivíduos.

Pesquisas que abordam a Sintaxe Espacial levam à análise da estrutura da configuração (padrões de mobilidade) como influente na circulação e deslocamento de modos motorizados e não motorizados. Hillier (2001) afirma que se for colocado um objeto em qualquer ponto dentro de um sistema espacial, certas consequências previsíveis afetarão a configuração espacial do ambiente. Esses efeitos são bastante independentes dos desejos ou da intenção humana, mas podem ser utilizados pelos seres humanos para alcançarem propósitos espaciais e até mesmo sociais. 
Esta teoria baseia-se em três conceitos básicos referentes ao espaço (Eloy, 2011): i) Isovistas polígono de visibilidade que representa o volume de espaço visível de um determinado ponto do espaço, ou seja, as Isovistas são uma interação entre a geometria e o movimento, para aspectos de percepção e cognição espacial; ii) Espaço axial - o espaço é representado por meio de grafos (axiais ou justificados) nos quais os compartimentos são representados por "nós" e as ligações por "vetores", esta representação reforça a noção de espaço e do movimento necessário para o percurso, assim como as características de acessibilidade e permeabilidade; iii) Espaço convexo - o espaço é considerado um vazio ocupado e representado por formas convexas, sendo que a representação convencional é feita de modo a que todos os pontos num polígono sejam visíveis pelos outros pontos do mesmo polígono.

“A sintaxe espacial contempla um método para estudos do espaço urbano ao possibilitar que fatores relacionados à configuração sejam matematicamente mensurados e claramente visualizados e, portanto, possam ser correlacionados com informações que envolvem investigações de natureza urbana" (Medeiros, 2013). Porém, para analisar características espaciais relacionadas com a geometria dos ambientes, Benedikt propôs as Isovistas, ou seja, um método que está baseado na relação entre usuário e ambiente, permitindo descrever e quantificar atributos envolvidos na percepção visual do ambiente, assunto que será abordado a seguir.

\subsubsection{Isovistas}

O conceito de Isovistas iniciou-se na arquitetura, na geografia e na matemática. De forma bem semelhante, o campo de arquitetura e urbanismo utilizou sob o disfarce do viewshed (Amidon e Elsner, 1968; Lynch, 1976). A palavra viewshed é utilizada para designar uma área de terra, de água ou de outro elemento do ambiente que é visível aos olhos humanos a partir de um determinado ponto de vista. É, portanto, uma região visível para um observador. Nos estudos que envolvem o uso de sistemas de informação geográfica, viewshed é a área visível a partir de uma localização específica.

O apelo do conceito de Isovistas é gerar um pensamento intuitivo e atraente sobre o ambiente espacial, pois fornece uma descrição do espaço "de dentro", a partir do ponto de vista dos indivíduos, como percebem, interagem e movem-se nele. Desta forma, as Isovistas têm uma importante relevância para a análise arquitetônica. 
Benedikt (1979) apresenta um conjunto de medições analíticas das propriedades das Isovistas, atingindo descrições quantitativas de ambientes espaciais, sendo o primeiro a utilizar o método para análise do espaço arquitetônico. Iniciou considerando o volume visível a partir de uma localização e, em seguida, simplificou essa representação, tomando uma fatia horizontal, gerando resultados sempre em forma de polígonos individuais. As Isovistas basicamente descrevem as propriedades geométricas dos locais no espaço para pontos individuais de observação e pesa todas as possíveis direções que podem ser vistas da mesma forma.

Benedikt (1979) considera área e perímetro como propriedades geométricas das Isovistas, assim, começou a quantificar o espaço, identificá-lo como poderia ser em diferentes percepções, e como seria a sua utilização. Isto o levou a formular um campo de Isovista por meio de suas medições, ou seja, os campos de Isovistas registrariam uma única propriedade de Isovista para todos os locais em uma configuração utilizando contornos para traçar a forma e também como essas características podem variar no espaço. Portanto, o autor descreve a Isovista como um conjunto de todos os pontos visíveis a partir de um determinado ponto escolhido no espaço, sugerindo tanto para a concepção de percepção visual e ecológica, como também para a classificação de tipos arquitetônicos.

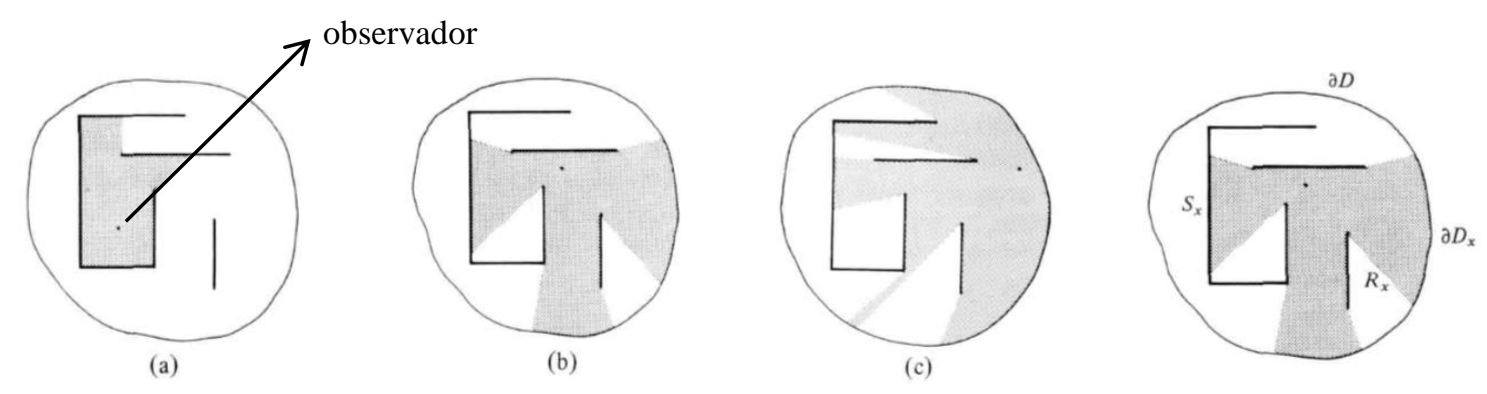

Figura 3.12 - Exemplos de Isovistas por Benedikt 1979

Batty (2001) também define Isovista como um campo de visão por meio do qual algumas propriedades geométricas, como área e perímetro, podem ser calculadas. As Isovistas podem ser definidas para cada ponto de um ambiente, e a união espacial de qualquer propriedade geométrica específica define uma área particular da Isovista.

Uma Isovista é a figura bidimensional resultante da intersecção da forma tridimensional constituída por todos os pontos visíveis e um plano horizontal na altura dos olhos do 
observador. O tamanho e a forma de uma Isovista, que se alteram com a mudança do ponto de observação, podem ser descritos por determinados atributos expressos em medidas numéricas:

- área: corresponde à quantidade de espaço visível a partir do ponto de vista;

- perímetro: corresponde à quantidade de superfícies visíveis do ambiente;

- oclusividade: descreve a profundidade entre as superfícies visíveis e oclusas no ponto de observação;

- variação: mede a dispersão do perímetro em relação ao ponto de vista;

- dissimetria: indica a simetria da dispersão do perímetro;

- circularidade: descreve o quanto uma Isovista é compacta ou complexa.

Especialmente para a análise das trajetórias de movimento individuais, as Isovistas parciais, com uma vista específica, podem ser aplicadas. As Isovistas parciais consideram apenas uma parte limitada do campo visual, teoricamente disponíveis (ex. $90^{\circ}$ ao invés de $360^{\circ}$ ). Elas correspondem melhor às restrições do aparelho visual humano. Estudos têm mostrado que os seres humanos codificam a informação espacial a partir do ponto de vista que eles a encontram.

A Isovista tem sido utilizada para fins ilustrativos em análise sintática do espaço, uma vez que fornece uma representação clara de áreas com maior visibilidade, proporcionando uma visão estratégica de uma determinada localização espacial que tende a ser mais intensamente utilizada. No entanto, apesar da importância da metodologia da Isovista de Benedikt, e sua estreita relação com as teorias de percepção visual e descrição espacial, aplicações das Isovistas têm sido limitadas a um pequeno número de estudos, embora mostrem como a percepção do espaço é afetada por vários de seus atributos.

\subsubsection{Pesquisas realizadas com a utilização das Isovistas}

A literatura apresenta uma série de aplicações da Teoria da Sintaxe Espacial no planejamento da mobilidade, que tratam tanto da circulação de pedestres quanto de veículos. Vários autores têm utilizado a formulação de Benedikt (1979) em estudos de caso de arquitetura. Por exemplo, Hanson (1994) utiliza Isovistas entre outros métodos, a fim de investigar a utilização dos espaços nas casas de vários arquitetos de renome. No entanto, embora o trabalho de Benedikt tenha um impacto sobre a forma como os indivíduos pensam sobre o espaço, tem havido relativamente pouco desenvolvimento do conceito de Isovistas ou 
metodologias relacionadas na literatura arquitetônica. Davis e Benedikt (1979) realizaram um estudo matemático mais formal de geração e localização da Isovista, e Benedikt e Burnham (1985) estudaram o impacto perceptivo das propriedades das Isovistas.

Batty (2001) utiliza mapas e gráficos para analisar as propriedades geométricas e estatísticas das Isovistas no interior de um museu e em duas amostras de parcelas urbanas, encontrando uma correlação entre variação da área, distância média e perímetro das Isovistas. O estudo sugere ainda um método para a definição de um conjunto mínimo de Isovistas que permita visualizar um complexo espacial por inteiro e também analisar a variação das Isovistas ao longo de um percurso. Como conclusão, o autor afirma que as Isovistas permitem ampliar a descrição da morfologia espacial para aspectos e cognição espacial ligados à interação entre geometria e movimento.

Franz e Wiener (2005), por sua vez, utilizam o modelo das Isovistas para analisar a influência da morfologia e da configuração espacial no comportamento humano e na experiência do espaço. As características visuais e espaciais do ambiente acabam por servir como ponto de decisão e, partindo de experimentos envolvendo a descrição do espaço e a navegação em ambientes virtuais, investigaram as interrelações entre as propriedades espaciais de ambientes e o comportamento, utilizando teorias qualitativas para provar a correlação entre dados comportamentais e espaciais, aplicando as Isovistas para explicar a variância nos dados comportamentais. O estudo correlaciona características qualitativas básicas do espaço tais como amplitude, permeabilidade, complexidade e ordem, a atributos quantitativos simples de Isovistas e grafos de visibilidade (VGA).

Era (2012) aplicou a sintaxe espacial nos espaços públicos e na rede pedonal da cidade de Granada (Andaluzia - Espanha). Ele considera que analisar a dimensão morfológica é necessário para compreender a influência nas medidas de acessibilidade dos pedestres no espaço público. O objetivo não foi testar ou validar o método da sintaxe espacial, mas de aplicá-lo para compreender a acessibilidade aos espaços públicos, considerando a qualidade dos ambientes em relação aos acessos das rotas para os pedestres.

Koch (2012) estuda as implicações das definições alternativas da teoria da lógica do espaço, considerando que a pessoa é um ponto de interpretação das entidades espaciais, o que permite 
diferentes interpretações e resultados. Seu foco é na descentralização dos campos visuais das pessoas e discute a base teórica para a análise de determinados fenômenos como alocentricidade (qualidade da cognição espacial para reconhecer a situação de "outro lugar") e o impacto de tal entendimento, por meio de operações sistêmicas.

Fujitani et al., (2012) desenvolveram modelos úteis para avaliar o espaço em edifícios comerciais utilizando a quantidade de pessoas (valor numérico) e a relação com a configuração do espaço. A partir destes modelos foram encontradas diferenças na distribuição das pessoas e as características do comportamento, criando-se modelos diferentes de acordo com a forma de construção (vertical ou horizontal) de cada edifício.

Zhang et al., (2012) estudaram os edifícios comerciais com grandes sistemas de circulação, incluindo entradas em diferentes andares e transições verticais complicadas entre os andares, dificultando a compreensão dos usuários em relação à configuração espacial, na área central de Xangai. Verificaram que é difícil a acessibilidade dos espaços e a disposição de instalações que não estão adequadas aos usuários.

Turner et al., (2012) apresentam um método para integrar as Isovistas com base nas conectividades representadas em gráficos, permitindo medidas relacionais globais. Utilizando estudos de caso do desenvolvimento das configurações urbanas, mostram que a integração das Isovistas exibe uma excelente correlação com o movimento de pessoas, incluindo uma ilustração mais detalhada do uso do espaço.

Ozer e Kubat (2007) acreditam que o movimento de pedestres é um dos pontos críticos no desenho urbano, mas existem poucos métodos para determinar a atratividade de uma área para pedestres. Esses autores realizaram um estudo abrangente sobre "walkability", desenvolvido em um centro histórico de Istambul, chamado Galata, que se tornou segregado nos últimos anos. Apesar de Galata ser uma região importante no núcleo comercial de Istambul e com uma rica história arquitetônica, cultural e religiosa, a região perdeu valor rapidamente, permanecendo desarticulada e rigidamente separada do seu entorno, em processo de deterioração. O estudo pesquisou os possíveis efeitos das variáveis ambientais sobre os níveis de atividade em espaços urbanos e constituiu um modelo analítico para futuras pesquisas sobre "walkability", e propostas para regenerar centros históricos da cidade que perderam sua 
vitalidade.

\subsection{SIG E O PROGRAMA SINTÁTICO-ESPACIAL}

Esta pesquisa utiliza duas ferramentas importantes para a realização do estudo das áreas com maior visibilidade para a localização de informações espaciais para o pedestre: um programa de Sistema de Informação Geográfica e o programa sintático-espacial Depthmap ${ }^{\circledR}$, apresentados a seguir.

\subsubsection{Sistema de Informação Geográfica}

Sistema de Informação Geográfica (SIG) é uma ferramenta computacional que possibilita uma interação das informações, agregando ao conjunto de mapas cartográficos dados de determinadas bases, aos vários usos dos programas computacionais.

Segundo Silva (1998), os programas SIG proporcionam aos usuários acesso às bases de dados (geográficas e/ou transportes), possibilitando a combinação de forma rápida e flexível desses elementos diferentes, sendo útil no planejamento urbano, no planejamento operacional de transportes e na análise de localidades mais vulneráveis.

Raia Jr. et al., (2001) também afirmam que por possuírem atributos geográficos (como coordenadas) e não geográficos, um Sistema de Informação Geográfica é uma ferramenta essencial para o georreferenciamento de locais mais vulneráveis nas cidades.

Câmara et al., (2000), contextualizam que o SIG é aplicado aos sistemas que fazem o tratamento de dados geográficos (georreferenciados), levando as informações por meio de dados numéricos e de características espaciais. Desta maneira, oferecem aos gestores e/ou planejadores uma visão inédita de seu ambiente de trabalho.

Um SIG é um sistema constituído por hardware, software e procedimentos, ou seja, realiza o tratamento computacional de dados geográficos, permitindo conexões entre diferentes atividades, baseado em sua proximidade geográfica. Construído para suportar a captura, gestão, manipulação, análise, modelação e visualização de informação referenciada no espaço, com o objetivo de resolver problemas complexos de planejamento e gestão que 
envolva a realização de operações espaciais.

\subsubsection{Depthmap}

Alguns programas computacionais são utilizados para a análise da configuração urbana e construção de mapas axiais ou das Isovistas. A teoria da Sintaxe Espacial utiliza, dentre outros, o Depthmap ${ }^{\circledR}$ como ferramenta para a análise da configuração urbana. O programa foi desenvolvido na University College London por Alasdair Turner em 2006 e disponibilizado para a comunidade acadêmica em 2011. Nesta pesquisa será utilizada a versão 2012, para a geração das Isovistas.

Medeiros (2013) ressalta que o Dephmap ${ }^{\circledR}$ possibilita uma integração com mais consistência entre as características topológicas e geométricas, pois incorpora aspectos métricos que possibilitam encontrar raios geométricos a partir de uma dimensão qualquer, ao invés de somente raios topológicos.

O programa Depthmap ${ }^{\circledR}$ foi utilizado em algumas pesquisas nas áreas de engenharia de tráfego e de transportes. Barros e Medeiros (2010), bem como Lopes e Cavalcante (2011), investigaram a mobilidade urbana, tendo como ferramenta de apoio este programa sintáticoespacial. Já Pereira et al., (2011) usaram em estudos relacionados ao desempenho de transportes urbanos.

Carmo (2013) afirma que os programas sintáticos, devido aos vários questionamentos relatados nos últimos anos, têm sido incrementados na tentativa de possibilitar uma análise configuracional levando em consideração as medidas topogeométricas.

\subsection{TÓPICOS CONCLUSIVOS}

Neste capítulo foi apresentado um conjunto de ferramentas úteis para o desenvolvimento deste estudo. A ferramenta oriunda da Teoria da Lógica Social do Espaço (Isovistas) que possibilita a identificação de elementos de orientação e continuidade no espaço para o pedestre e as demais ferramentas utilizadas em estudos relacionados aos deslocamento de pedestres com o viés explorativo da forma urbana da cidade (configuração urbana). 


\section{MÉTODO PARA DETERMINAÇÃO DA LOCALIZAÇÃO DE UNIDADES DE INFORMAÇÕES ESPACIAIS PARA PEDESTRES}

\subsection{APRESENTAÇÃO}

Como discorrido nos capítulos anteriores, as pessoas para se sentirem confiantes e mais motivadas para se deslocarem a pé, necessitam de infraestrutura adequada e principalmente de autonomia para escolher seus próprios caminhos, chegando ao destino final com segurança e, muitas vezes com mais rapidez. Para isso é necessário planejar em uma escala mais humana, ou seja, produzir informações dos espaços públicos, com detalhes de rotas, distância, tempo de caminhada, destinos mais procurados, entre outros, pois a disponibilização de informações espaciais aos pedestres promove uma maior orientação e apropriação dos espaços, significando a compreensão das cidades e suas diversas formas urbanas.

A importância de se planejar cidades para as pessoas, em escala humana, reforça a necessidade de manter o indivíduo informado sobre seus tempos de percursos e rotas, culminando assim no foco desta pesquisa que é a determinação de uma localização para unidades de informações para os deslocamentos dos pedestres, assegurando que não é suficiente ter informações, mas sim é fundamental saber a localização e a quantidade adequada dessas informações para, assim, não gerar mais dúvidas e inseguranças aos pedestres.

A Teoria da Sintaxe Espacial, aplicada ao planejamento da mobilidade, tem como um dos seus focos a circulação de pedestres e a utilização das Isovistas, conforme proposto primeiramente por Benedikt (1979), no qual os estudos têm um impacto importantíssimo sobre a forma como os indivíduos pensam a respeito do espaço. Ozer e Kubat (2007), por exemplo, acreditam que o movimento de pedestres é um dos pontos críticos no desenho urbano. Estudos realizados com a utilização das Isovistas podem ser encontrados em artigos publicados no International Space Syntax Symposiums, que, em 2015, realizará sua $10^{\circ}$ edição em Londres (Inglaterra).

Para o alcance do objetivo principal deste estudo, recomenda-se que a aplicação deste método seja precedida de dados e informações confiáveis das proximidades (áreas de influências) do sistema de transporte público. 
A disponibilização de pontos de referências de unidades de informações aos pedestres, além de proporcionar uma maior apropriação dos espaços públicos, vai ao encontro do planejamento em escala humana, onde os pedestres deixam de ser um grupo preterido e passam a ser a prioridade das cidades, pois as cidades mais seguras, vivas e sustentáveis dão importância às escalas humanas.

Neste contexto, o método exposto a seguir apresentará primeiramente as considerações conceituais para sua utilização, em seguida será apresentado o quadro geral com as quatro fases, e o passo a passo de cada uma, e, por último, a descrição das quatro fases apresentadas no item 4.3 em etapas metodológicas.

\subsection{CONSIDERAÇÕES CONCEITUAIS PARA A UTILIZAÇÃO DO MÉTODO}

Serão abordados neste tópico os conceitos que estabelecem o entendimento do fenômeno e dos elementos necessários para a sua utilização. Esses conceitos partem do referencial teórico utilizado nesta pesquisa, relatado nos capítulos anteriores, enfatizando que as cidades precisam ser planejadas e construídas para pessoas (em escala humana) e que o espaço urbano precisa ser atrativo, convidativo, com elementos de referência que facilitem a orientação e a apropriação do espaço, visando à continuidade, a liberdade e a segurança para se deslocar.

Dentre esses elementos, conceitua-se:

- Ponto de unidade de informação: o local no espaço onde será colocado um elemento físico (ícones, totens, mapas de sinalização, etc.) que trará informações de uma região ou área, contendo informações de localização, de orientação, dos serviços urbanos que possam ser oferecidos, como também serviços em termo de mobilidade para o pedestre.

- Área de influência: área virtual estabelecida com um raio de 500 metros de ação, no qual o indivíduo, ao se localizar e se deslocar no espaço, consumirá o mesmo tempo para qualquer ponto na região compreendida. A representação dessa área é diversificada assumindo formas que dependerão do espaço físico, como figuras geométricas conhecidas: círculos, quadrados ou representação amorfa.

- Divisão da área de influência: é a categorização temporal das áreas de influência 
medida pelo tempo de percurso no espaço urbano, representado pelas isócronas. $\mathrm{O}$ deslocamento segue a mesma rota natural que os pedestres fazem se deslocando no espaço, considerando suas impedênacias. Analogicamente essa categorização foi feita utilizando as cores: verde - significa uma área de percurso com no máximo 5 minutos da infraestrutura do sistema de transporte público, ou seja, o indivíduo ainda está próximo de um ponto de parada, estação do metrô, etc.; amarelo - significa atenção, pois a distância de percurso já é razoável até uma infraestrutura do sistema transporte público, chegando até 10 minutos de caminhada; e vermelho - significa pare e procure uma orientação, pois a sua distância de percurso até uma infraestrutura do sistema de Transporte Público já passa de 10 minutos de caminhada. Vale ressaltar que as cores estão diretamente relacionadas à distância do deslocamento do pedestre, em minutos, para uma infraestrutura de transporte como uma estação, um ponto de parada, ou até mesmo uma passarela que sirva de acesso ao sistema de transporte público.

- Área verde (até 5 minutos) - indivíduo tem uma liberdade de deslocamento, tem mais facilidade para encontrar seu destino final.

- Área amarela (a partir dos 5 até 10 minutos) - já esta em uma área que precisa de mais atenção para o deslocamento, podendo não se lembrar das rotas ou percursos mais curtos e simples.

- Área vermelha (a partir dos 10 minutos) - é necessário encontrar um ponto de referência para orientar-se e seguir a caminhada até o seu destino final.

- Caminhos dos pedestres: representados pelas isócronas, o caminho que qualquer indivíduo poderá realizar independentemente da infraestrutura existente para o seu deslocamento (como passeios, calçadas) e que será levantada a fim de traçar o caminho real que o pedestre percorre no espaço (área de influência).

Isócronas para esta pesquisa é entendida como "sucessões de linhas que representam a distância em que é possível se deslocar a velocidades constantes, em períodos iguais de tempo" (O’Sullivan et al., apud Miller e Shaw, 2001).

- Áreas de visibilidade: é a área de referência para o pedestre, conseguindo observar e identificar as referências de continuidade, ou seja, o indivíduo consegue do primeiro 
ponto enxergar o segundo, existindo um entendimento da continuidade da rota (percurso), sendo que uma das técnicas que permitem trazer este elemento na continuidade do espaço são as Isovistas.

\subsection{ETAPAS METODOLÓGICAS}

O trabalho seguirá as etapas metodológicas apresentadas na Figura 4.13. O método tem como base o uso do solo nas áreas de influência das estações do sistema de transporte público e a demanda de viagens de usuários em um mês típico do ano ou de todos os meses acumulados de 2013. 


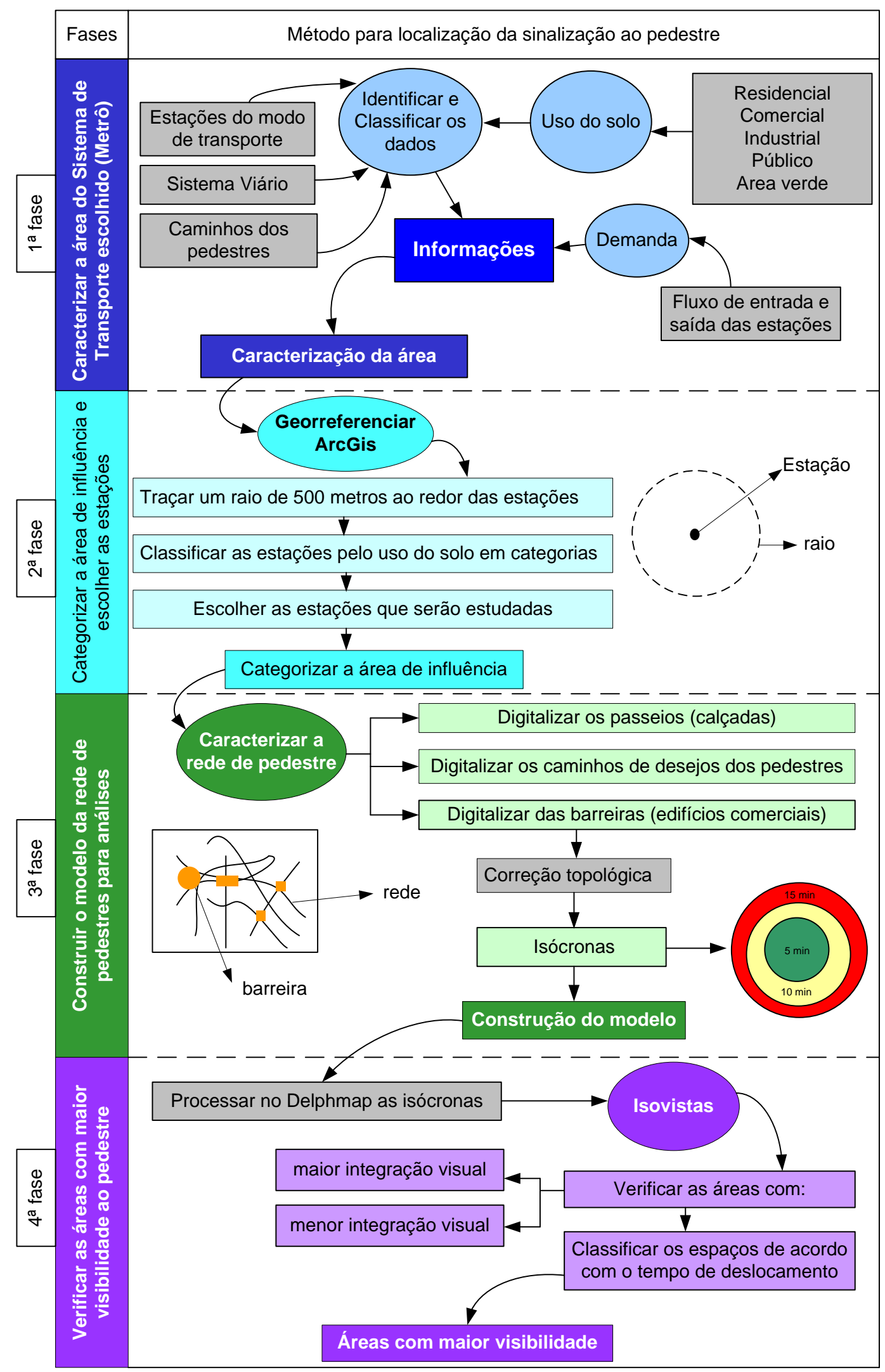

Legenda Ferramentas e objetivos Ações e resultados

Figura 4.13 - Passo a passo do método para localização da sinalização ao pedestre 
As quatro fases que compõem a estrutura do método são as seguintes:

$1^{a}$ fase: Caracterizar toda área de estudo do Sistema de Transporte escolhido;

$2^{\mathrm{a}}$ fase: Categorizar a área de influência e escolher as estações;

$3^{\text {a }}$ fase: Construir o modelo da rede de pedestres para análises;

$4^{\mathrm{a}}$ fase: Verificar as áreas com maior visibilidade ao pedestre.

\subsection{1 $1^{\mathrm{a}}$ Fase: Caracterizar toda área de estudo do Sistema de Transporte escolhido}

O objetivo desta primeira fase é caracterizar a área de estudo do Sistema de Transporte Público escolhido para pesquisa. Para isso, é necessário obter os dados: Sistema de Transporte Público, Uso do Solo, Sistema Viário e as Rotas dos pedestres.

- sistema de transporte público: coletar e classificar os modos do sistema de transporte público terrestre, dividindo-o em rodoviário e metroviário, contendo a localização das suas estações e a quantidade de linhas ativas existentes. Coletar dados de demanda e oferta, ou seja, coletar os dados de entrada e saída (fluxo de demanda) das estações em um dia típico do ano ou acumulado dos meses de todo o ano (2013);

- identificar o sistema viário e classificá-lo;

- levantar os dados sobre o uso do solo nas regiões próximas às estações e classificá-las conforme o plano diretor em residencial, comercial, industrial, área verde, etc.

Ainda nesta fase, objetiva-se gerar as informações para serem utilizadas em um sistema de coordenadas geográficas, conforme Figura 14.4.

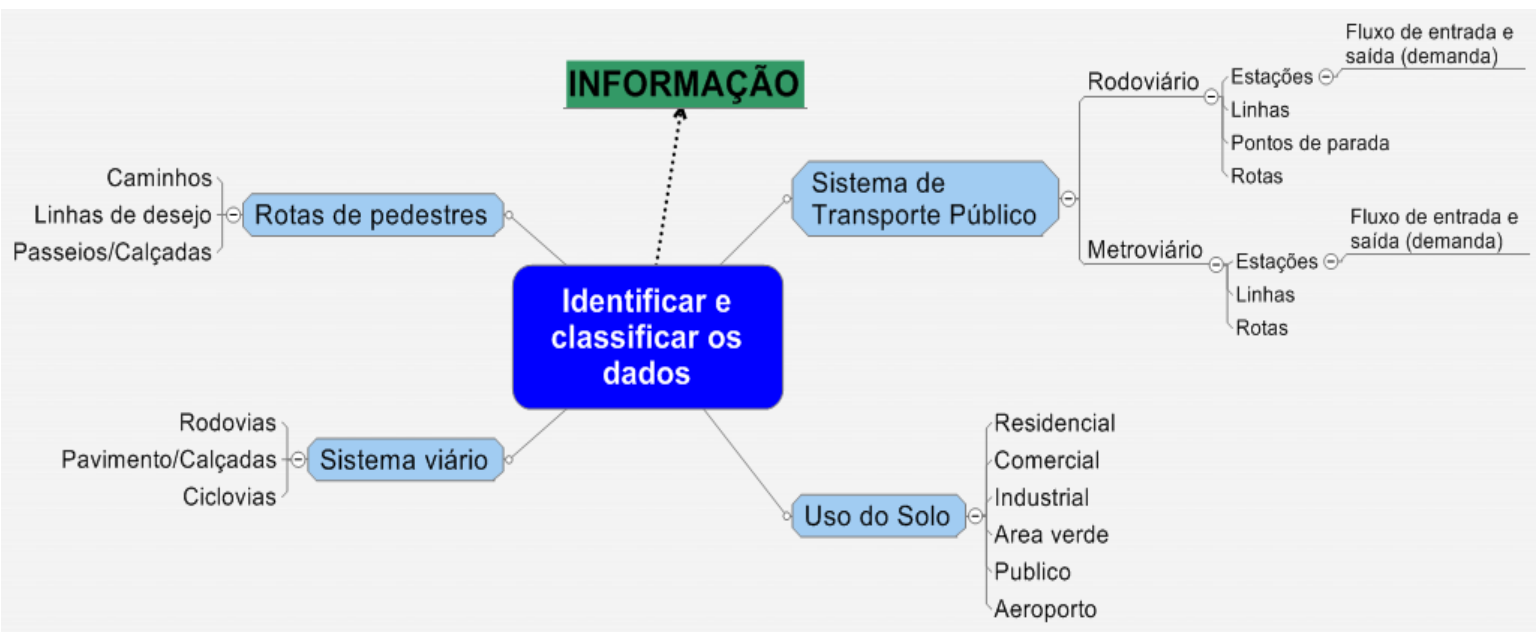

Figura 4.14 $-1^{a}$ fase - Caracterizar toda área do Sistema de Transporte escolhido 


\subsection{2 $2^{\mathrm{a}}$ Fase: Categorizar a área de influência e escolher as estações}

O objetivo desta fase é escolher as estações que serão estudadas segundo a caracterização realizada na primeira fase. Para realizar esta escolha, é necessário utilizar a ferramenta de um sistema de informações geográficas (SIG). Com a utilização deste software é possível obter as informações em camadas, como: camadas do uso do solo, do sistema viário, etc. Após escolher o sistema de transporte público que será estudado, utilizar as camadas das estações para desenhar um raio de 500 metros ao redor das estações que será denominada de área de influência de cada estação. A utilização de um raio de 500 metros está baseado nos preceitos de Vukan (2007).

Em seguida, conforme Figura 4.15, analisar e categorizar o uso do solo, utilizando a classificação do governo local (Secretaria de Habitação do Estado ou afins), como residencial, comercial, industrial, entre outras, sempre considerando o número de elementos presentes na área de influência e desta forma as áreas poderão ser classificadas com um ou mais tipos de uso do solo, exemplo: Residencial ou Residencial/Area Verde. Após a classificação das estações pelo uso do solo, é possível escolher quantas estações são representativas e quantas serão estudas, levando em consideração também o fluxo de entrada e saída de pessoas em um dia útil de um mês típico do ano, colhidas na primeira fase do método.

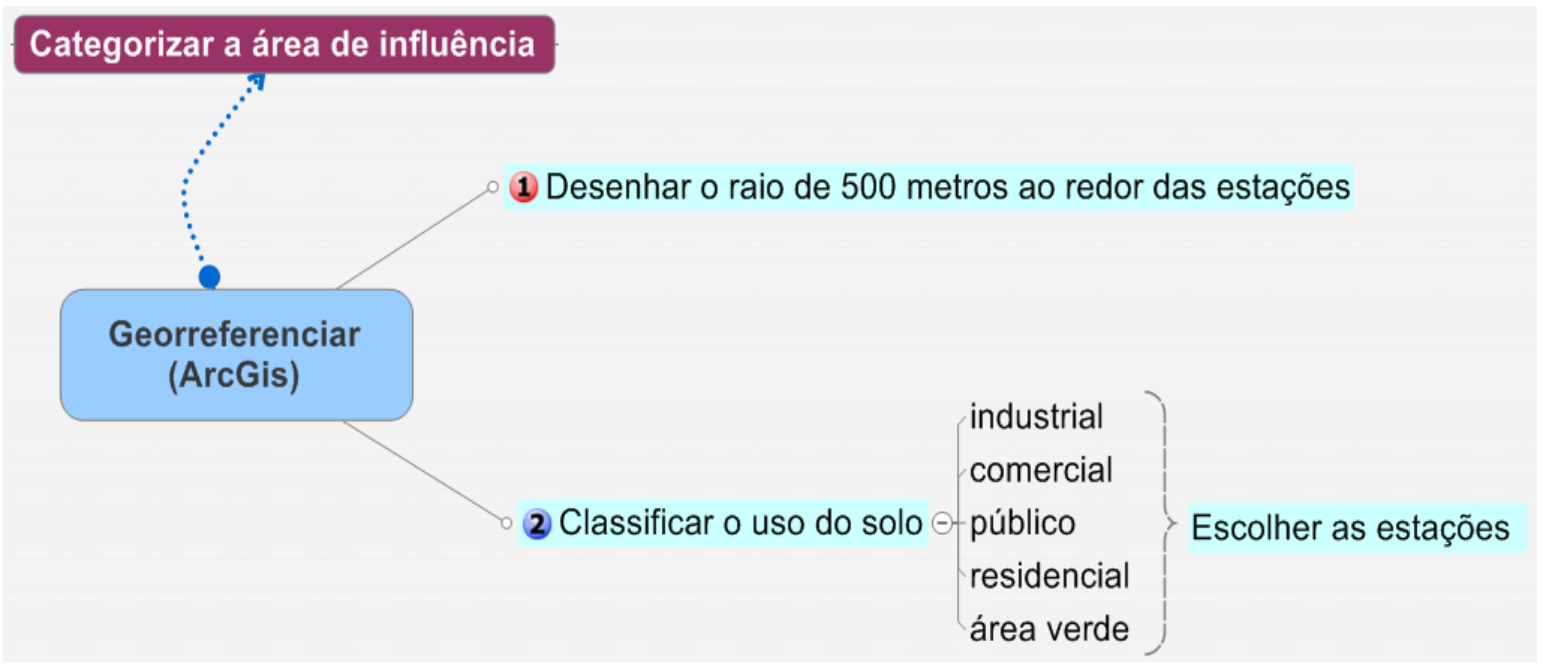

Figura 4.15 - $2^{\mathrm{a}}$ fase - Categorizar a área de influência e escolher as estações 


\subsection{3 $3^{\mathrm{a}}$ Fase: Construir o modelo da rede de pedestres para análises}

O objetivo desta fase conforme Figura 4.16, é construir o modelo da rede de pedestres para posterior análise no programa Depthmap ${ }^{\circledR}$ na quarta fase. Uma vez caracterizadas, classificadas e escolhidas às estações que serão estudadas na pesquisa, é possível a construção das redes de pedestres (simples) nas áreas de influências no SIG. A velocidade dos pedestres adotada neste estudo será de $4 \mathrm{~km} / \mathrm{h}$, conforme aponta o Manual on Uniform Traffic Control Devices (2009).

A área de influência de cada estação teve por princípio o desenho do raio de 500 metros (com base nos preceitos de Vukan, 2007), e considerando todas as impedâncias (barreiras) serão digitalizados os caminhos de desejos dos pedestres e as calçadas quando presentes. A rede de pedestres simples será construída no SIG, levando em consideração todas as barreiras existentes. Entende-se por barreira nesta pesquisa, edifícios, ruas com alta velocidade, igrejas, escolas, e quaisquer obstáculos que dificultem ou impossibilitem a travessia pelos pedestres. Estas barreiras podem ser designadas como impedâncias, ou seja, tudo aquilo que interrompa ou modifique o deslocamento dos pedestres.

Uma rede é uma abstração da realidade que representa um sistema de movimento e tal rede pode ser de tráfego, de informação, etc. Está composta por duas entidades fundamentais que são: os nós, que representam pontos de entrada e saída da rede, os pontos onde mudam as características físicas e/ou geométricas dos arcos e os pontos de interseção dos arcos, e os arcos, que representam as entidades que ligam os nós. Em uma rede de transporte para os pedestres, os arcos representam as vias por onde eles circulam. Uma vez construída a rede de pedestres, é possível utilizar a função disponível do SIG network analysis para gerar as isócronas.

As isócronas são curvas que resultam da união de pontos que contem um valor igual de tempo, o qual é calculado em função da velocidade dos pedestres que se deslocam em uma rede, ou seja, mediante uma rede que apresente como atributos: velocidade, comprimento e tempo. Assim geram polígonos que representam a área atingida em função da velocidade e da distância em um intervalo de tempo determinado. 


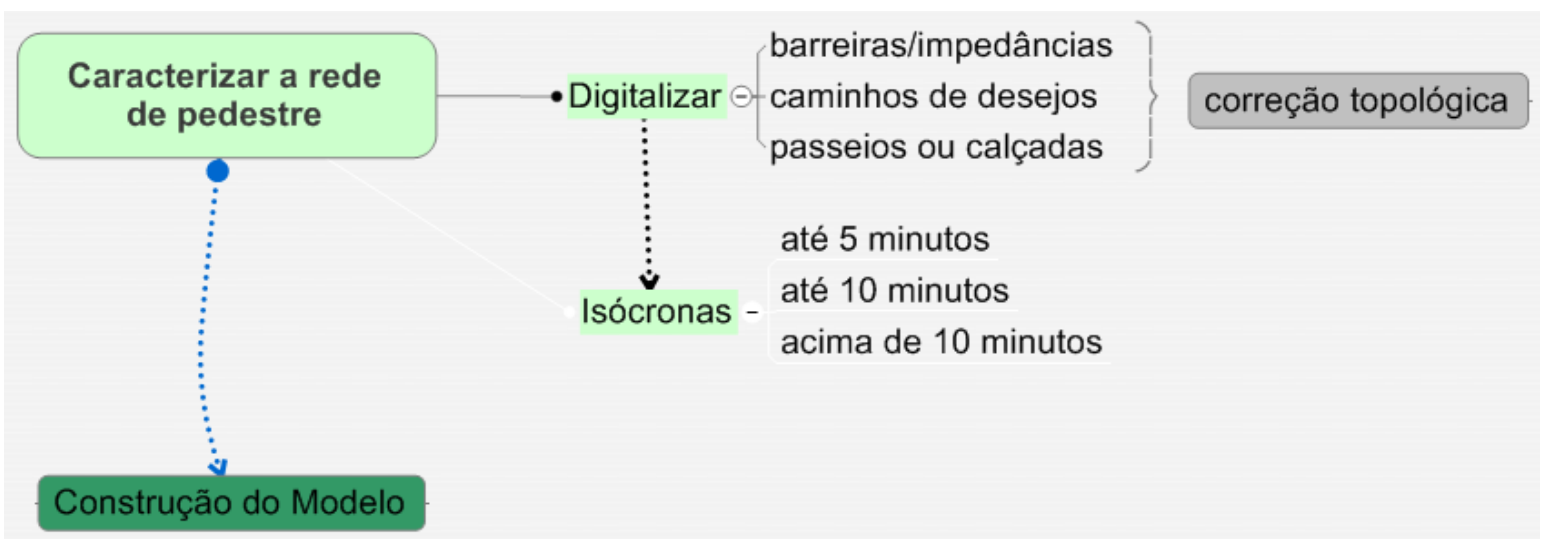

Figura 4.16 $-3^{\mathrm{a}}$ fase - Construir o modelo da rede de pedestres para análises

\subsection{4 $\quad 4^{\mathrm{a}}$ Fase: Verificar as áreas com maior visibilidade ao pedestre}

O objetivo desta fase conforme Figura 4.17, é identificar e analisar as áreas com maior visibilidade ao pedestre. Para tanto, pretende-se, após a construção do modelo, processá-lo por meio de Isovistas no Depthmap ${ }^{\circledR}$. Após rodadas as Isovistas, é possível verificar o nível de integração das áreas com maior ou menor visibilidade.

Após a identificação das áreas com maior ou menor visibilidade, também será possível classificar os espaços de acordo com o tempo de deslocamento nas áreas de influências das estações. A classificação temporal dos espaços será de acordo com os intervalos de tempo de até 5 minutos, até 10 minutos e acima de 10 minutos. Com a classificação e identificação das áreas com maior visibilidade, sugere-se a localização de informações espaciais para o deslocamento dos pedestres.

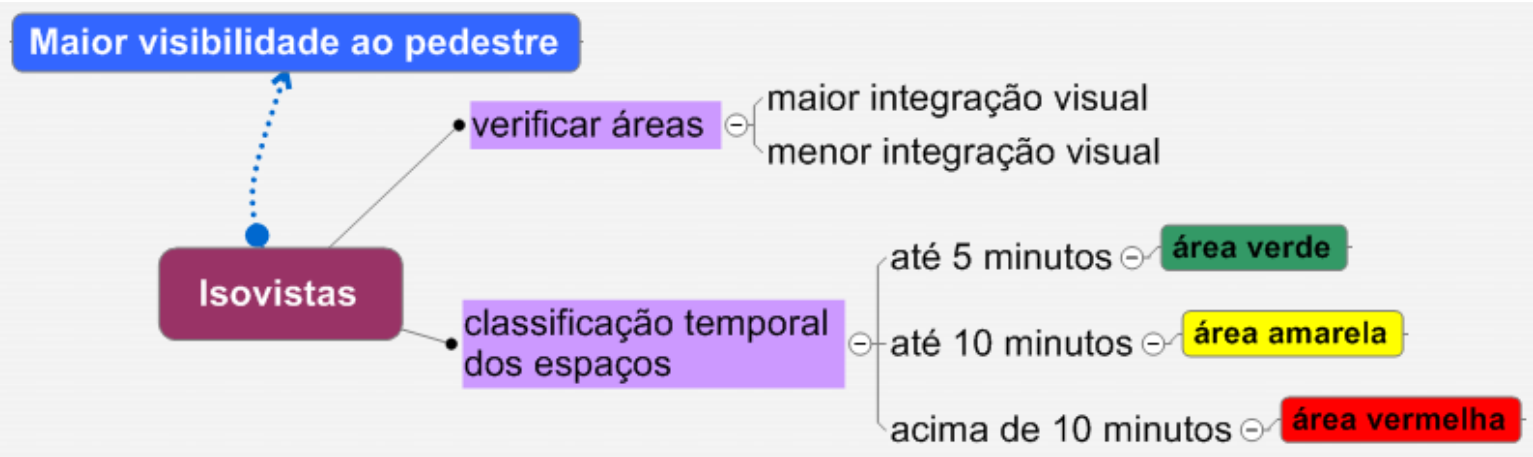

Figura 4.17 $-4^{\mathrm{a}}$ fase - Verificar as áreas com maior visibilidade ao pedestre 


\subsection{TÓPICOS CONCLUSIVOS}

O método desenvolvido apresenta potencialidade de aplicação, principalmente para analise do transporte público e sua relação com o espaço, visto que considera os elementos relacionados aos pedestres e seus deslocamentos. Para a sua aplicabilidade se faz necessário uma caracterização de toda área de estudo bem como uma categorização das estações de transportes da cidade. Dessa forma será possível integrar o modo a pé de deslocamento aos demais modos de transportes públicos. Para o estudo de caso, as estações metroviárias do Distrito Federal foram escolhidas. 


\section{APLICAÇÃO DO ESTUDO: ESTAÇÕES METROVIÁRIAS DO DISTRITO FEDERAL}

\subsection{APRESENTAÇÃO}

Sendo o recorte escolhido para o estudo de caso a determinação da localização de unidades de informações espaciais para o deslocamento de pedestres nas áreas de influências das estações do sistema de transporte metroviário (metrô) do Distrito Federal, as malhas urbanas de Brasília, atravessadas pelo sistema de transporte público citado serão descritas nos tópicos seguintes.

\subsection{RESTRIÇÕES DA APLICAÇÃO}

Este estudo utilizou o banco de dados do ano de 2013 fornecido pela Secretaria de Habitação, Regularização e Desenvolvimento Urbano do Distrito Federal - Sedhab. Não foram feitos ajustes nas áreas de influências das estações do metrô, considerando que estão caracterizadas completamente, conforme a realidade atual de uso do solo. Outra questão importante para se considerar se refere à concepção modernista da cidade, o que lhe atribuiu setorizações funcionais, e a existência de muitos espaços vazios em virtude, seja por sua concepção original, seja pela não execução total do projeto, ou ainda, em virtude do caráter relativamente recente do adensamento populacional da jovem cidade.

Importante salientar que as ferramentas de leitura da Sintaxe do Espaço requerem a decodificação do sistema em suas barreiras (cheios, que não podem ser vistos e/ou percorridos) e permeabilidades (vazios, que podem ser visto e/ou percorridos). Em alguns estudos de caso a aplicação do método passará por uma ponderação metodológica, e isso se dará justamente quando a área analisada incluir grandes vazios de circulação, apresentando um número baixo de impedâncias (espaços sem barreiras), pois a base para a interpretação está nos vazios que se relacionam e a tendência é que nesse espaço livremente percorrido o valor de integração seja maior por simplesmente não apresentar barreiras, e não necessariamente porque formem caminhos ou redes que possam ser utilizados pelos pedestres.

Dessa forma, para estes casos, os valores de maior visibilidade e integração visual, oriundos da distribuição cromática, onde as áreas mais vermelhas são as de melhor desempenho, enquanto as azuis apresentam mais restrições visuais, não serão aqueles que virão das áreas 
mais vermelhas e sim das áreas que apresentarem um tom amarelado ou verde. Ademais, as distâncias de deslocamento em Brasília são superiores às distâncias percorridas em cidades como Rio de Janeiro ou São Paulo, pela morfologia e a concepção modernista com os grandes espaços vazios.

Considerando também que das 29 (vinte e nove) estações ativas do metrô de Brasília, 21 (vinte e uma) delas, ou seja, mais de $60 \%$ (sessenta por cento) das estações estão situadas em área predominantemente residencial, 1 (uma) predominantemente comercial, 2 (duas) predominantemente de áreas verdes, 2 (duas) comercial e residencial e 3 (três) comercial e pública, desta maneira, o estudo de caso fica contemplado com cinco classificações de uso de solo.

\subsection{CONTEXTUALIZAÇÃO DO METRÔ DO DISTRITO FEDERAL}

\subsubsection{O Distrito Federal}

O Distrito Federal-DF está dividido em 31 (trinta e uma) Regiões Administrativas, sendo Brasília a Região Administração número 1 (um) - RA-01. Brasília é formada pela Asa Norte, Asa Sul, Setor Militar Urbano, Setor de Garagens e Oficinas, Setor de Indústrias Gráficas, Área de Camping, Eixo Monumental, Esplanada dos Ministérios, Setor de Embaixadas Sul e Norte, Vila Planalto, Granja do Torto, Vila Telebrasília, Setor de áreas Isoladas Norte, e sedia os três poderes da República: Executivo, Legislativo e Judiciário. Segundo dados do IBGE de 2013, o DF possui aproximadamente 2,8 milhões de habitantes, com uma densidade demográfica aproximada de 445 habitantes por quilômetro quadrado. A economia do DF é baseada em comércio e serviços, destacando-se o serviço público nesse cenário.

Brasília foi construída com a finalidade de ser a nova capital do país, transferindo-a para o interior. O Plano Piloto de Brasília foi concebido a partir dos preceitos do urbanismo modernista em meados do século XX. A existência de grandes espaços entre os demais núcleos integrantes do sistema urbano vem gerando desde então fragmentação e descontinuidade. Tudo isso fez inverter a premissa das cidades de serem caracterizadas pela densidade do espaço construído em oposição ao vazio das ruas, praças e largos (Barros; Medeiros, 2013). Os autores também afirmam que "Brasília filia-se a um fundamento urbanístico peculiar e resulta de uma concepção global (cidade pensada como um todo), seguindo os preceitos da urbanística moderna desenvolvida na primeira metade do século XX, 
a partir de uma lógica vinculada a Era da Máquina”.

Silva (2008) relata que o conjunto urbano do Distrito Federal foi estruturado de forma 'polinuclear', tendo como centro o Plano Piloto, e as cidades satélites foram localizadas fora da bacia do lago Paranoá. Medeiros (2013) enfatiza que, ao longo do século XX, as ênfases para a interpretação da cidade eram tradicionalmente narrativas ou descritivas, cujas abordagens detêm-se nas relações econômicas, políticas, culturais, históricas, entre outras, não parecendo haver avanço nos estudos sobre a maneira pela qual a forma-espaço, em outras palavras, o conjunto de cheios e vazios que compõe a cidade afetava as relações, categoria relevante para a compreensão dos fenômenos urbanos, indo ao encontro do estudo da forma urbana e suas interferências no cotidiano das pessoas, retratado por Jane Jacobs, Kevin Lynch e Jan Gehl, apresentados no segundo capítulo desta pesquisa.

Desde sua construção, houve grande preocupação para que a Brasília modernista mantivesse as suas escalas urbanísticas e os seus valores estético-funcionais. No ano de 1987, o Plano Piloto de Brasília foi declarado Patrimônio Histórico da Humanidade pela Unesco, sendo o único conjunto urbano construído no século XX a receber o título. Assim, a conceituação das quatro escalas do plano urbanístico de Lúcio Costa (monumental, residencial, gregária e bucólica) e os valores essenciais, de cada uma delas, devem ser preservados; bem como os graus de valor do patrimônio de acordo com os valores fundamentais das áreas da cidade devem ser observados. O grau principal é o que restringe as intervenções urbanísticas (obras e construções), no Plano Piloto como um todo, por exemplo, nas superquadras, no Eixo Monumental, nos setores centrais da cidade e na orla do lago Paranoá. Em grau secundário e, portanto, com menos restrições, estão protegidos lugares como o Cruzeiro, o Sudoeste e o Noroeste, o Setor de Indústrias Gráficas e o Setor de Garagens Oficiais, entre outros, conforme registrado no Plano de Preservação do Conjunto Urbanístico (PPCUB).

O novo PPCUB começou a ser debatido no ano 2011. Foram quatro anos de intensa discussão. Em cinquenta e quatro anos, Brasília mudou significativamente em relação às suas necessidades, e a mobilidade urbana, por exemplo, tornou-se uma questão premente. Desta forma, o PPCUB prevê a adoção de tecnologias modernas de transporte público, a renovação de áreas consideradas obsoletas e subutilizadas, além de prever que os setores deverão ser aproveitados para múltiplas atividades, e não apenas para uma destinação específica. 


\subsubsection{O Metrô do Distrito Federal}

Os primeiros estudos técnicos para o metrô de Brasília foram realizados no ano de 1991. As obras começaram em 1992, e, em 1997, foram realizadas as primeiras viagens experimentais. Em agosto de 1998, o Metrô-DF começou a operar em regime experimental, e somente em 2001 iniciou a sua operação em definitivo. Silva (2008) retrata que o metrô está construído no principal eixo de transporte coletivo do Distrito Federal, composto pelas regiões administrativas de Taguatinga, Ceilândia, Samambaia, Guará e Águas Claras. Portanto, ele foi concebido e construído no eixo de maior concentração de população do Distrito Federal, com 909.886 habitantes, no ano de 2000, representando cerca de $54 \%$ (cinquenta e quatro por cento) da demanda total de transporte coletivo (Codeplan, 2000).

Em sua configuração atual, o sistema metroviário de Brasília, conforme Figura 5.18, apresenta uma frota de 32 trens e cobre $46,5 \mathrm{~km}$ de linha em funcionamento, que liga a Rodoviária do Plano Piloto à Ceilândia e Samambaia, passando pelo Eixo Rodoviário Sul e pelas regiões administrativas de Guará, Águas Claras e Taguatinga. O sistema opera de segunda a sexta-feira no horário de $6 \mathrm{~h}$ as $23 \mathrm{~h} 30$, e nos finais de semana, de $7 \mathrm{~h}$ as $19 \mathrm{~h}$. As estações estão abertas ao público e têm fluxos variados conforme mostra a Tabela 5.3 na página 67.

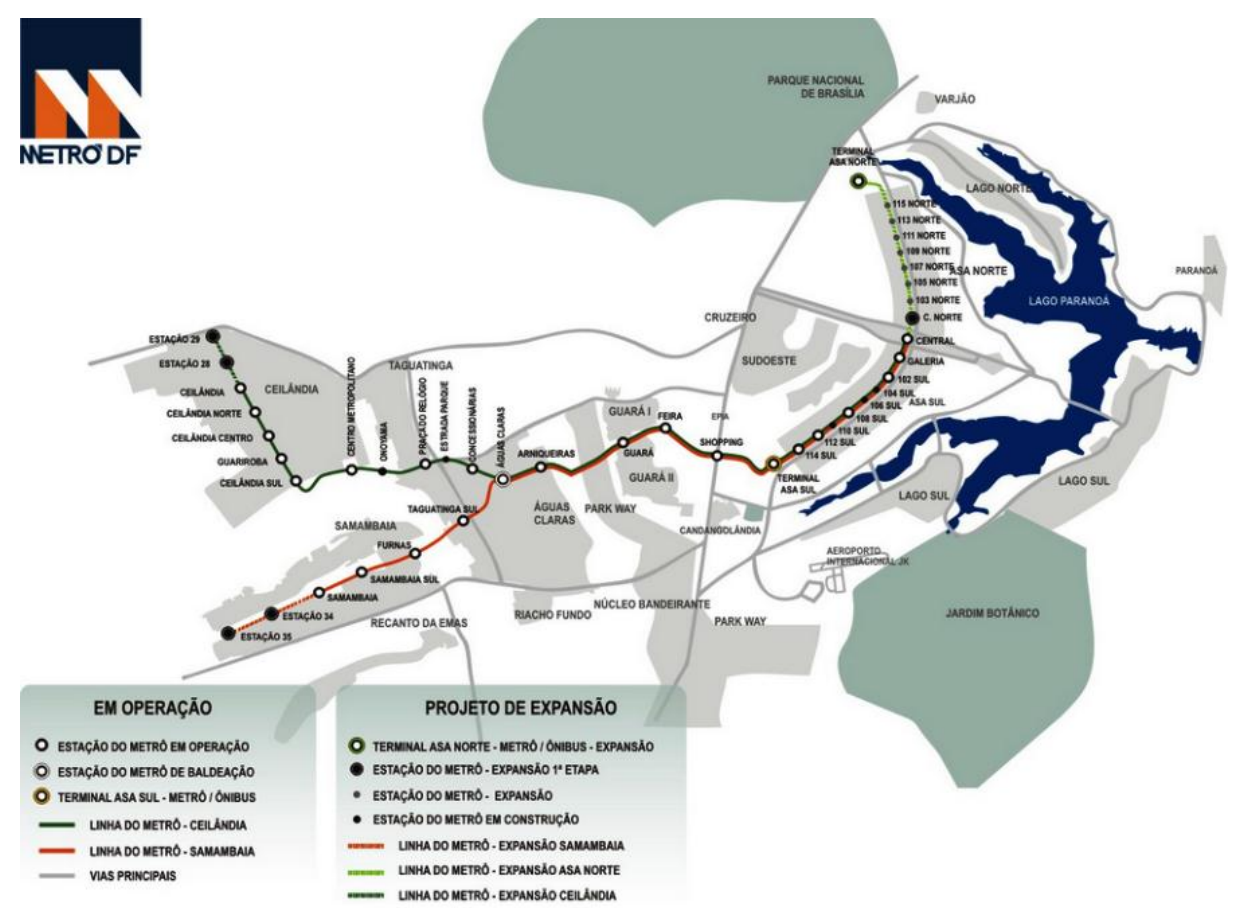

Figura 5.18 - Estações do Metrô Brasília

Fonte: Site do Metrô-DF (www.metro.df.gov.br) 
Conforme Tabela 5.1, encontrada nos estudos de Barros e Medeiros (2013), a caracterização geral do sistema metroviário de Brasília é a seguinte:

\begin{tabular}{ll}
\hline DADOS & BRASÍLIA \\
\hline Número de habitantes & 2.570 .160 \\
Número de habitantes (Metrópole) & 3.717 .728 \\
Área $(\mathrm{km} 2)$ & $5.787,78$ \\
Densidade populacional (hab/km2) & 444,07 \\
Extensão do metrô $(\mathrm{km})$ & 46,5 \\
Densidade de linhas $(\mathrm{km}$ linhas/km2) & 0,01 \\
Número de estações de metrô em operação & 29 \\
Número de estações de metrô em construção & 5 \\
Densidade de estações (Qtd./km2) & 0,005 \\
Distância média entre estações $(\mathrm{km})$ & 1,722 \\
\hline
\end{tabular}

Tabela 5.1 - Dados gerais de Brasília metropolitana

Fonte: Barros e Medeiros (2013) com adaptações

O sistema metroviário existente em Brasília procura alcançar aqueles trechos de maior densidade populacional, embora, para tanto, precise atravessar significativos vazios. Conforme Barros e Medeiros (2013), "existem estações em pontos nodais da dinâmica da capital, como a estação Shopping, que permitem acessos aos grandes empreendimentos comerciais e de serviços distribuídos ao longo da via EPIA, a de maior integração do sistema urbano".

\subsection{APLICAÇÃO DO ESTUDO DE CASO NO METRÔ DO DISTRITO FEDERAL}

Após a coleta de informações geográficas do metrô do Distrito Federal, utilizando um programa SIG, a primeira ação para começar a aplicação do estudo de caso é traçar o raio de 500 metros ao redor de todas as estações operantes e classificá-las pelo uso de solo, desta forma será possível diagnosticar os diversos tipos de áreas de influências. Após a classificação do uso do solo, será possível desenhar uma rede de pedestres, considerando todo tipo de impedância para o pedestre, ou seja, todo tipo de barreiras que impeçam a livre circulação das pessoas. Em seguida, serão gerados os mapas de cada estação para a obtenção das isócronas com três tempos pré-determinados (5,10 e 15 minutos). Com isso, será possível construir o modelo e processá-lo no Depthmap ${ }^{\circledR}$ para obtenção das áreas visualmente mais integradas e da indicação das possíveis áreas para as informações espaciais aos pedestres utilizando as variáveis: área da isovista que corresponde aos campos de maior visibilidade em um determinado sistema; raio máximo da isovista que indica os pontos que possuem um campo de visão de maior alcance linear e integração visual que indica os pontos que são 
visualmente mais integrados.

\subsubsection{Descrição das estações e classificação}

A Figura 5.19 mostra as 29 (vinte nove) estações e suas áreas de influência. Das 29 (vinte e nove) estações, 21 (vinte e uma) delas foram classificadas como predominantemente residencial, 1 (uma) predominantemente comercial, 2 (duas) predominantemente de áreas verdes, 2 (duas) comercial e residencial e 3 (três) comercial e pública, limitando o estudo de caso para cinco classificações de uso de solo. Foram escolhidas 5 (cinco) estações para a realização do estudo de caso.

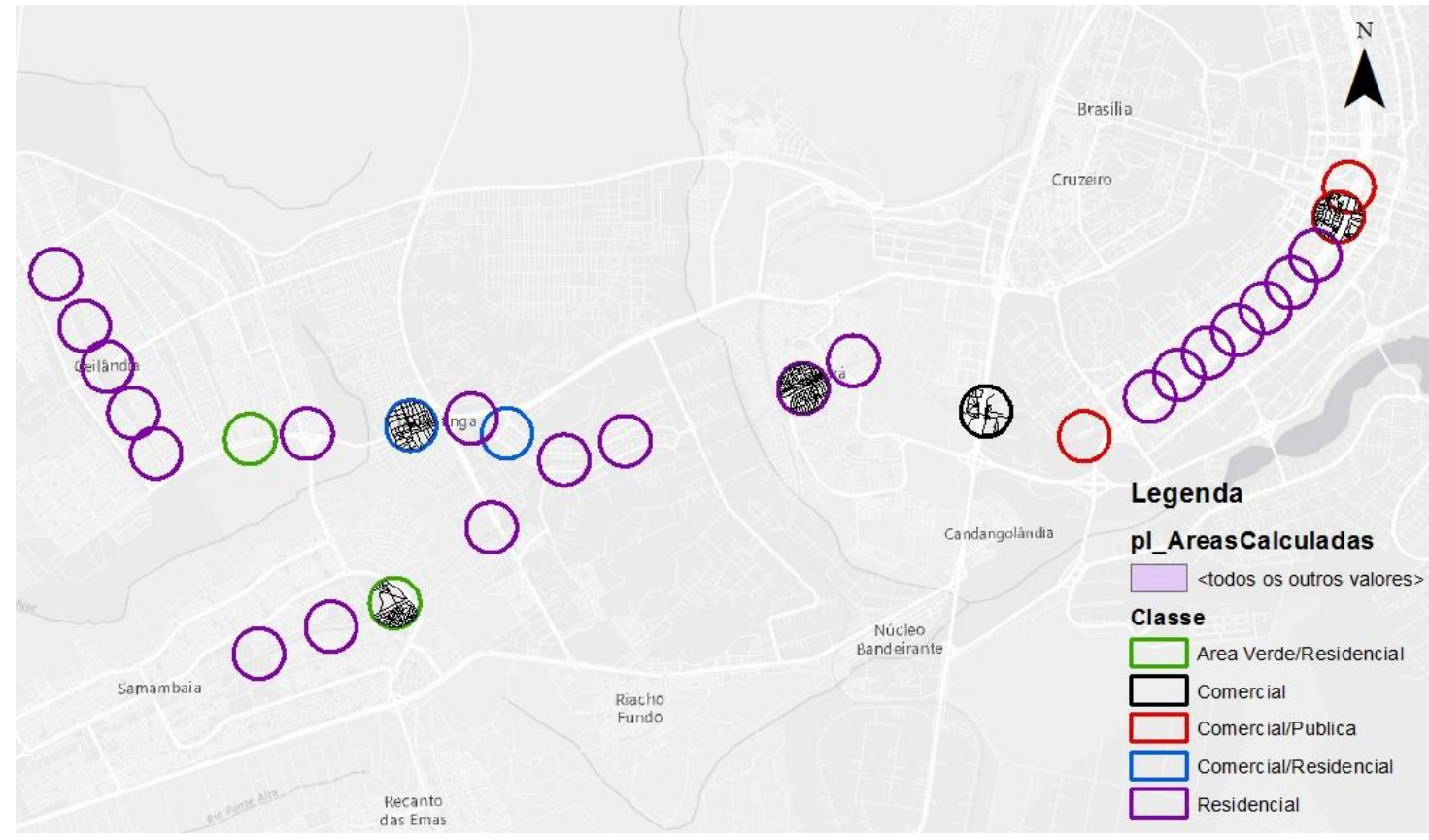

Figura 5.19 - Estações do Metrô de Brasília - DF

A classificação do uso do solo foi realizada por meio da utilização de mapas de uso de solo publicados, em formato CAD, pela Sedhab - Secretaria de Estado de Habitação, Regularização e Desenvolvimento Urbano do Distrito Federal, na página virtual no endereço de Internet www.sedhab.org.br. Foi realizada a conversão para o formato 'shape', tornando-o compatível com o programa ArcGis®, e assim facilitar a análise geográfica. As áreas foram recortadas, classificadas e analisadas dentro do raio de 500 metros ao redor das estações. Vale lembrar que os mapas fornecidos são do ano de 2013 e que foi considerado que estão fidedignos aos tempos atuais. A Figura 5.20 mostra a divisão em porcentagens das áreas construídas nas áreas de influências (raio de 500 metros) com a classificação do uso do solo. 


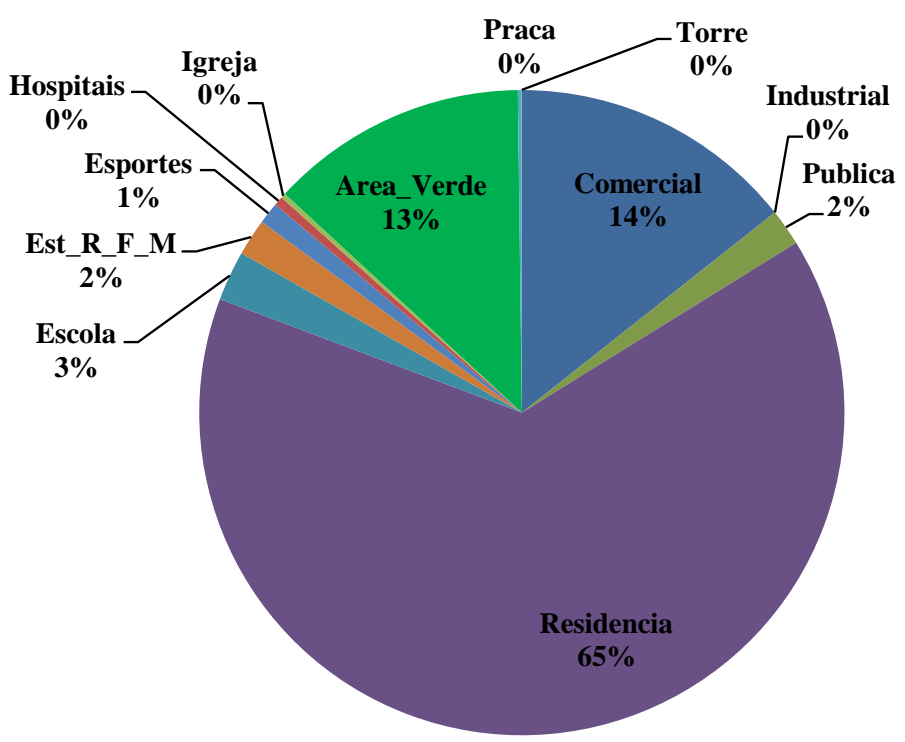

Figura 5.20 - Porcentagem de áreas construídas conforme uso do solo

Na Tabela 5.2, são mostrados os 12 (doze) tipos de classificação do uso de solo utilizada na pesquisa. Os valores encontrados permitiram a classificação das áreas de influência das estações. Devido ao fato de Brasília ser uma cidade setorizada e não possuir estações perto de indústrias, torres e aeroportos, estas classificações não geraram nenhum valor e não influenciaram nas escolhas das estações para estudo. Outro fator decisivo nas escolhas das estações são os fluxos (acumulado) de passageiros por estação no ano de 2013, fornecidos pelo Metrô-DF, observados na Tabela 3. Para escolher as estações, em primeiro lugar, foi considerado o valor da área construída dentro do raio de 500 metros e, depois, foi levado em conta o fluxo de passageiros. Na Figura 5.20, é possível notar que existem três grandes tipos de uso de solo nas áreas de influências das estações que são: residencial, comercial e área verde. Esses tipos foram combinados com os outros, gerando mais duas classificações: Comercial/Pública, Comercial/Residencial e Área verde/ residencial, desta forma foram contempladas cinco classificações de uso do solo.

No item 5.4.2 serão apresentadas as estações escolhidas para o estudo. 


\begin{tabular}{|c|c|c|c|c|c|c|c|c|c|c|c|c|c|}
\hline $\mathrm{n}$. & Estações & Comercial & Industrial & Publica & Residencial & Escola & Est_R_F_M & Esportes & Hospitais & Igreja & Area_verde & Praça & Torre \\
\hline 1 & Central & 7543,6 & 0,0 & \begin{tabular}{|l|}
9850,9 \\
\end{tabular} & 1076,2 & 0,0 & 0,0 & 0,0 & 0,0 & 0,0 & 0,0 & 0,0 & 0,0 \\
\hline 2 & Galeria dos Estados & 38956,3 & 0,0 & 13389,0 & 806,4 & 0,0 & 0,0 & 0,0 & 4288,9 & 0,0 & 0,0 & 0,0 & 0,0 \\
\hline 3 & $102 \mathrm{Sul}$ & 10321,9 & 0,0 & 286,4 & 17715,1 & 1074,5 & 0,0 & 0,0 & 573,3 & 681,6 & 2481,8 & 0,0 & 0,0 \\
\hline 4 & $104 \mathrm{Sul}$ & 12109,1 & 0,0 & 15,2 & 22721,6 & 336,5 & 0,0 & 0,0 & 0,0 & 1393,6 & 3075,6 & 0,0 & 0,0 \\
\hline 5 & $106 \mathrm{Sul}$ & 16677,4 & 0,0 & 0,0 & 19184,7 & 1024,2 & 0,0 & 3525,1 & 0,0 & 15,5 & 1122,1 & 0,0 & 0,0 \\
\hline 6 & $108 \mathrm{Sul}$ & 18131,6 & 0,0 & 897,9 & 45288,5 & 1899,9 & 0,0 & 5894,0 & 0,0 & 81,4 & 4942,7 & 0,0 & 0,0 \\
\hline 7 & $110 \mathrm{Sul}$ & 11693,0 & 0,0 & 434,3 & 34339,0 & 0,0 & 0,0 & 0,0 & 0,0 & 49,4 & 4721,5 & 5374,5 & 0,0 \\
\hline 8 & $112 \mathrm{Sul}$ & 11154,6 & 0,0 & 1385,5 & 39363,7 & 2537,2 & 0,0 & 4442,2 & 0,0 & 23,1 & 8313,9 & 0,0 & 0,0 \\
\hline 9 & $114 \mathrm{Sul}$ & 10883,7 & 0,0 & 0,0 & 38652,4 & 4382,6 & 0,0 & 3776,6 & 0,0 & 33,7 & 8711,0 & 0,0 & 0,0 \\
\hline 10 & Asa Sul & 0,0 & 0,0 & 3460,1 & 158,5 & 0,0 & 0,0 & 13,1 & 2021,0 & 0,0 & 0,0 & 0,0 & 0,0 \\
\hline 11 & Shopping & 93214,8 & 0,0 & 798,7 & 223,0 & 0,0 & 21437,5 & 0,0 & 0,0 & 0,0 & 1358,6 & 0,0 & 0,0 \\
\hline 12 & Feira & 12234,4 & 0,0 & 933,2 & 88930,3 & 103,7 & 1809,1 & 10247,3 & 1564,8 & 0,0 & 5116,4 & 0,0 & 0,0 \\
\hline 13 & Guará & 2924,1 & 0,0 & 909,8 & 131688,0 & 23,1 & 0,0 & 0,0 & 0,0 & 0,0 & 0,0 & 0,0 & 0,0 \\
\hline 14 & Arniqueiras & 3482,4 & 0,0 & 0,0 & 27700,9 & 0,0 & 972,9 & 168,3 & 0,0 & 0,0 & 0,0 & 0,0 & 0,0 \\
\hline 15 & Águas Claras & 9941,6 & 0,0 & 0,0 & 42084,4 & 0,0 & 4072,4 & 0,0 & 0,0 & 0,0 & 0,0 & 0,0 & 0,0 \\
\hline 16 & Concessionárias & 10181,4 & 0,0 & 427,2 & 20279,8 & 0,0 & 2076,4 & 0,0 & 0,0 & 0,0 & 0,0 & 0,0 & 367,5 \\
\hline 17 & Praça do Relógio & 86622,5 & 0,0 & 11111,9 & 64139,7 & 7458,3 & 0,0 & 0,0 & 136,4 & 2056,6 & 0,0 & 0,0 & 0,0 \\
\hline 18 & Centro Metropolitano & 0,0 & 0,0 & 2101,0 & 68970,7 & 1138,7 & 7348,0 & 223,1 & 0,0 & 0,0 & 193724,0 & 0,0 & 0,0 \\
\hline 19 & Ceilândia Sul & 2459,6 & 0,0 & 0,0 & 170321,0 & 5857,9 & 665,6 & 0,0 & 0,0 & 0,0 & 0,0 & 0,0 & 0,0 \\
\hline 20 & Guariroba & 3852,7 & 0,0 & 1229,0 & 173078,0 & 19298,2 & 987,0 & 0,0 & 664,2 & 1439,3 & 0,0 & 0,0 & 0,0 \\
\hline 21 & Ceilândia Centro & 11015,3 & 0,0 & 0,0 & 129087,0 & 4411,0 & 1849,6 & 0,0 & 910,4 & 280,6 & 0,0 & 0,0 & 0,0 \\
\hline 22 & Ceilândia Norte & 2414,2 & 0,0 & 1376,5 & 145836,0 & 6060,2 & 0,0 & 0,0 & 0,0 & 0,0 & 0,0 & 0,0 & 0,0 \\
\hline 23 & Ceilândia & 4339,5 & 0,0 & 2053,9 & 200712,0 & 7107,7 & 0,0 & 0,0 & 1021,6 & 802,7 & 0,0 & 0,0 & 0,0 \\
\hline 24 & Estrada Parque & 705,4 & 0,0 & 0,0 & 8772,6 & 0,0 & 0,0 & 0,0 & 0,0 & 0,0 & 0,0 & 0,0 & 0,0 \\
\hline 25 & Onoyama & 872,0 & 0,0 & 0,0 & 45038,3 & 7884,2 & 0,0 & 1370,8 & 1068,3 & 0,0 & 33007,6 & 0,0 & 0,0 \\
\hline 26 & Taguatinga Sul & 9335,2 & 0,0 & 0,0 & 79746,5 & 554,4 & 2634,8 & 0,0 & 1032,5 & 97,5 & 0,0 & 0,0 & 0,0 \\
\hline 27 & Furnas & 0,0 & 0,0 & 0,0 & 31690,5 & 436,2 & 3399,0 & 0,0 & 0,0 & 0,0 & 94679,9 & 0,0 & 0,0 \\
\hline 28 & Samambaia Sul & 0,0 & 0,0 & 1680,0 & 113939,0 & 0,0 & 2568,3 & 0,0 & 0,0 & 0,0 & 0,0 & 0,0 & 0,0 \\
\hline 29 & Samambaia & 18976,0 & 0,0 & 0,0 & 83006,5 & 0,0 & 2900,9 & 1249,5 & 0,0 & 0,0 & 8425,9 & 0,0 & 0,0 \\
\hline
\end{tabular}

Tabela 5.2 - Classificação do Uso do Solo 
Fluxo de Passageiros por Estação - Ano 2013 - Acumulado de Janeiro a Dezembro

\begin{tabular}{|c|c|c|c|c|c|c|c|c|c|c|c|c|c|}
\hline ESTAÇÃO & JAN & FEV & MAR & ABR & MAI & JUN & JUL & AGO & SET & OUT & NOV & DEZ & TOTAL \\
\hline Central & 459.833 & 450.789 & 508.565 & 589.898 & 543.109 & 598.678 & 614.785 & 611.609 & 592.417 & 606.988 & 555.336 & 513.761 & 6.645 .768 \\
\hline Galeria & 182.742 & 177.708 & 211.239 & 238.641 & 231.249 & 227.083 & 243.267 & 244.360 & 237.992 & 240.729 & 226.068 & 191.722 & 2.652 .800 \\
\hline $102 \mathrm{Sul}$ & 59.822 & 72.994 & 80.979 & 89.594 & 89.685 & 90.216 & 85.430 & 95.064 & 90.135 & 88.242 & 87.349 & 73.245 & 1.002 .755 \\
\hline $108 \mathrm{Sul}$ & 52.679 & 62.536 & 75.755 & 82.721 & 85.226 & 83.426 & 76.340 & 87.119 & 82.884 & 81.672 & 80.923 & 64.417 & 915.698 \\
\hline $112 \mathrm{Sul}$ & 46.314 & 56.448 & 71.547 & 79.254 & 76.074 & 74.625 & 66.742 & 77.983 & 79.727 & 77.568 & 76.156 & 62.079 & 844.517 \\
\hline $114 \mathrm{Sul}$ & 68.337 & 76.211 & 89.110 & 100.441 & 100.980 & 96.257 & 91.630 & 103.808 & 98.549 & 99.404 & 97.587 & 78.885 & 1.101 .199 \\
\hline Asa Sul & 14.642 & 19.766 & 25.386 & 29.071 & 26.164 & 26.458 & 23.800 & 30.824 & 28.478 & 24.853 & 21.841 & 16.693 & 287.976 \\
\hline Shopping & 249.664 & 230.206 & 238.069 & 254.822 & 260.362 & 254.380 & 301.033 & 266.640 & \begin{tabular}{|l|}
253.128 \\
\end{tabular} & 261.080 & 259.984 & 270.856 & 3.100 .224 \\
\hline Feira do Guara & 72.730 & 78.853 & 93.516 & 98.000 & 100.924 & 98.708 & 98.767 & 102.960 & 99.295 & 93.525 & 96.157 & 94.956 & 1.128 .391 \\
\hline Guara & 126.606 & 139.779 & 158.571 & 172.243 & 175.645 & 170.332 & 172.037 & 180.451 & \begin{tabular}{|l|}
174.088 \\
\end{tabular} & 174.492 & \begin{tabular}{|l|}
166.490 \\
\end{tabular} & 140.944 & 1.951 .687 \\
\hline Arniqueiras & 206.732 & 217.423 & 245.363 & 271.144 & 270.215 & 264.972 & 273.607 & 287.418 & \begin{tabular}{|l|}
269.592 \\
\end{tabular} & 272.191 & \begin{tabular}{|l|}
259.956 \\
\end{tabular} & 213.035 & 3.052 .648 \\
\hline Agua Claras & 162.731 & 204.138 & 246.840 & 280.623 & 272.214 & 236.052 & 230.248 & 274.228 & 265.426 & 263.298 & \begin{tabular}{|l|}
227.286 \\
\end{tabular} & 169.616 & 2.832 .700 \\
\hline Concessionárias & 87.960 & 90.980 & 106.836 & 115.935 & 113.272 & 107.595 & 108.477 & 117.846 & 113.402 & 112.792 & 106.537 & 95.866 & 1.277 .498 \\
\hline Praça do Relógio & 216.912 & 239.051 & 275.278 & 299.304 & 296.963 & 281.632 & 284.165 & 300.340 & 287.505 & 285.308 & 285.892 & 273.223 & 3.325 .573 \\
\hline Centro Metropolitano & 86.289 & 90.545 & 106.372 & 118.531 & 117.080 & 113.133 & 118.630 & 120.364 & \begin{tabular}{|l|}
115.130 \\
\end{tabular} & 112.127 & 109.765 & 100.779 & 1.308 .745 \\
\hline Ceilândia Sul & 85.265 & 90.348 & 105.266 & \begin{tabular}{|l|}
122.048 \\
\end{tabular} & 122.087 & 116.323 & 118.503 & 120.068 & \begin{tabular}{|l|}
119.661 \\
\end{tabular} & 118.067 & \begin{tabular}{|l|}
114.913 \\
\end{tabular} & 112.241 & 1.344 .790 \\
\hline Guariroba & 67.405 & 69.459 & 74.277 & 84.623 & 82.144 & 77.618 & 76.215 & 65.465 & 74.997 & 77.445 & 74.577 & 61.239 & 885.464 \\
\hline Ceilândia Centro & 153.194 & 153.674 & 181.107 & 200.415 & 198.247 & 189.251 & 198.591 & 201.164 & 190.666 & 185.193 & 180.029 & 186.435 & 2.217 .966 \\
\hline Ceilândia Norte & 60.321 & 62.055 & 70.850 & 77.065 & 77.172 & 74.005 & 76.438 & 76.544 & 74.243 & 74.115 & 72.102 & 74.175 & 869.085 \\
\hline Terminal Ceilândia & 126.188 & 133.618 & 160.540 & 173.462 & 174.002 & 166.842 & 172.674 & 174.961 & 171.583 & 169.644 & 166.965 & 146.296 & 1.936 .775 \\
\hline Taguatinga Sul & 60.663 & 68.889 & 82.445 & 94.287 & 92.851 & 90.690 & 85.382 & 99.354 & 96.701 & 95.438 & 92.236 & 77.923 & 1.036 .859 \\
\hline Furnas & 110.493 & 114.220 & 124.323 & 138.262 & 140.182 & 135.513 & 142.858 & 145.886 & \begin{tabular}{|l|}
142.701 \\
\end{tabular} & 141.375 & 135.941 & 112.652 & 1.584 .406 \\
\hline Samambaia Sul & 73.297 & 75.138 & 84.712 & 99.032 & 97.274 & 95.274 & 96.129 & 101.694 & 99.389 & 99.891 & 96.801 & 77.924 & 1.096 .520 \\
\hline Terminal Samambaia & 87.995 & 92.078 & 108.649 & 119.171 & 119.353 & 116.862 & 119.769 & 126.131 & 121.172 & 122.101 & 124.852 & 109.333 & 1.367 .466 \\
\hline
\end{tabular}

Tabela 5.3 - Fluxo de Passageiros por estação - 2013 Fonte: Metrô-DF 


\subsubsection{Estações escolhidas}

Após a classificação dos tipos de uso do solo e a observância dos dados de fluxo de passageiros por estação no ano de 2013, foram escolhidas 5 (cinco) estações para serem estudadas. Para cada estação escolhida, foram digitalizados os caminhos/rotas e as barreiras (impedâncias) que os pedestres possuem dentro da área de influência. A seguir, serão apresentadas as oito estações em ordem de distância da estação do centro do Plano Piloto, ou seja, da estação Centro/ Rodoviária.

\section{1) Estação Galeria}

A estação Galeria é a primeira depois da estação Central, sentido Samambaia Sul ou Terminal Ceilândia. Está localizada no bairro Asa Sul (região administrativa de Brasília), parte da área tombada pela UNESCO. Foi classificada como Comercial/Pública, pois concentra uma quantidade grande de órgãos governamentais no Setor Comercial Sul, além de possuir em seus arredores um shopping de grande porte (Pátio Brasil Shopping) e dois outros de médio porte (Venâncio 2000 e CONIC). A Figura 5.21 traz a área de influência da estação e os caminhos/rotas de pedestres traçados. A Figura 5.22 mostra o percentual do uso de solo para a área construída no raio de 500 metros.

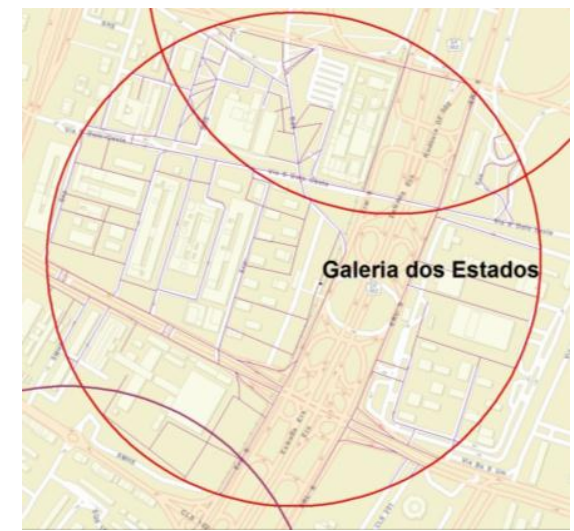

Figura 5.21 - Estação Galeria

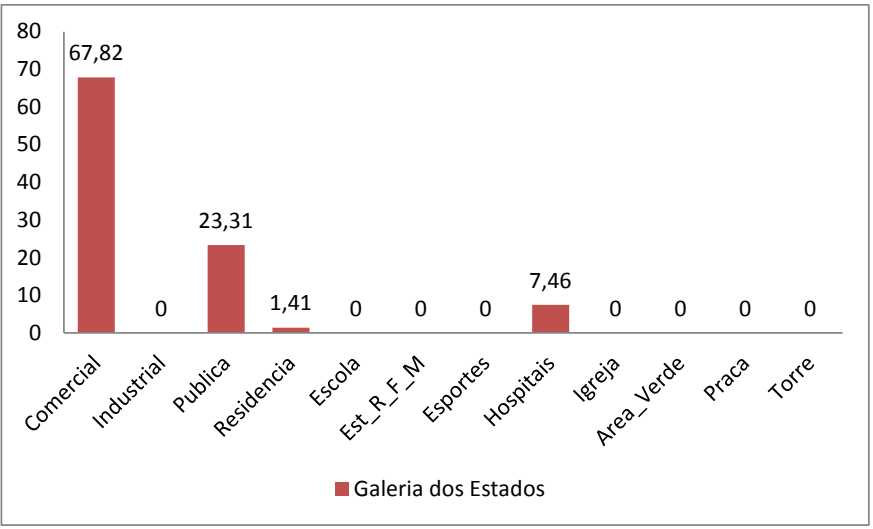

Figura 5.22 - Classificação do uso do solo - Galeria

A Figura 5.23 mostra os caminhos que os pedestres podem seguir ao sair da estação Galeria. O diagnóstico ao redor da estação indica a precariedade de informações disponibilizadas aos pedestres, retirando deles a autonomia de escolha de rotas e o planejamento de viagem, bem como favorecendo a falta de apropriação do espaço. 


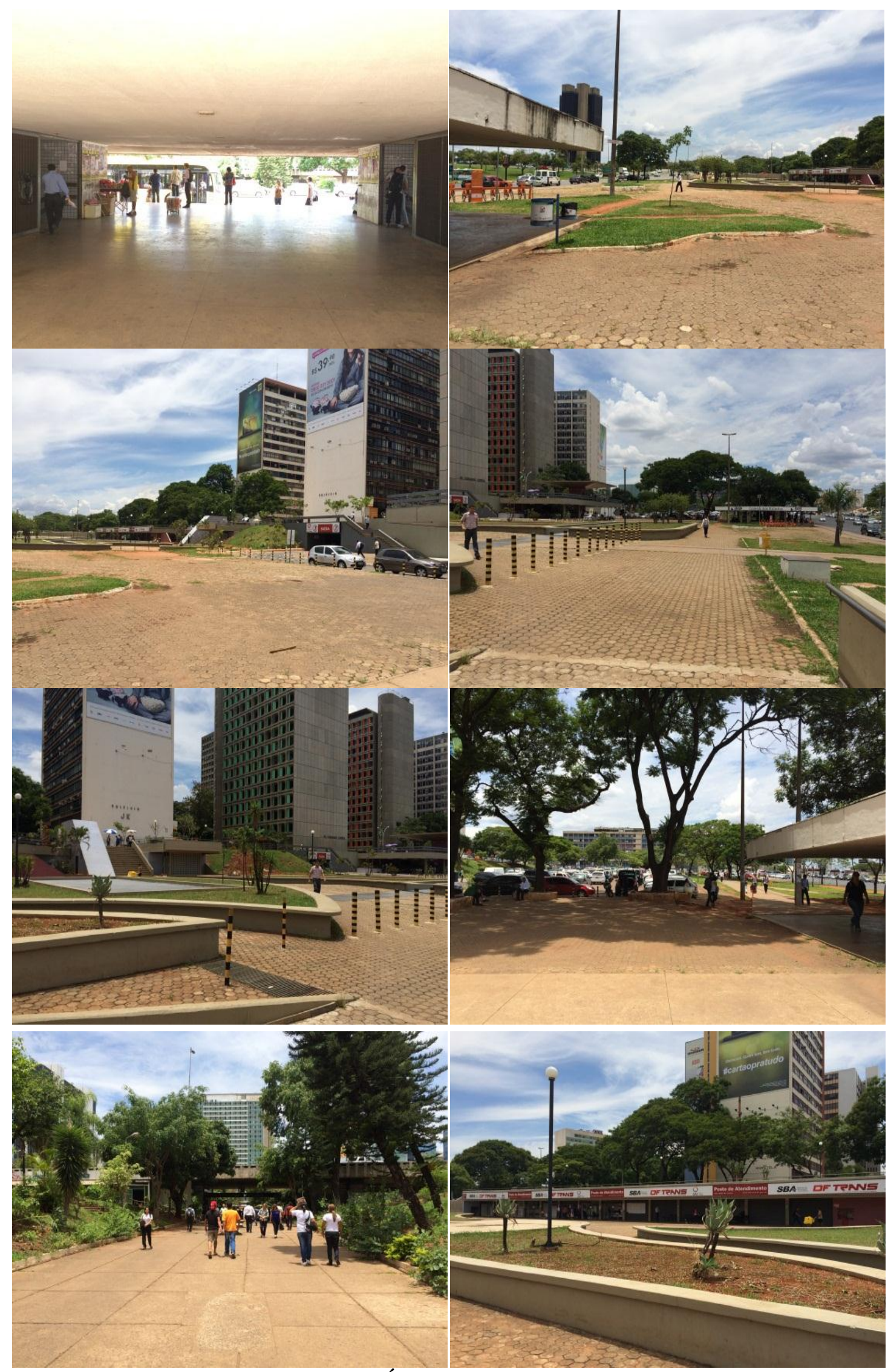

Figura 5.23 - Área de influência da estação Galeria 


\section{2) Shopping}

A estação Shopping localiza-se ao longo da EPIA (Estrada Parque Indústria e Abastecimento). Ao seu redor, estão localizados equipamentos urbanos que caracterizam as centralidades contemporâneas de grandes metrópoles, ou seja, grandes shoppings, hipermercados, etc., não existindo uma escala humanizada para os pedestres. Esses equipamentos são montados para uma estrutura em que o deslocamento é feito prioritariamente pelo automóvel individual, o que significa que possivelmente exista uma série de dificuldades com o deslocamento de pedestres ao sair da estação Shopping. A Figura 5.24 traz a área de influência da estação e os caminhos/rotas de pedestres traçados. A Figura 5.25 mostra o percentual do uso de solo para a área construída no raio de 500 metros.

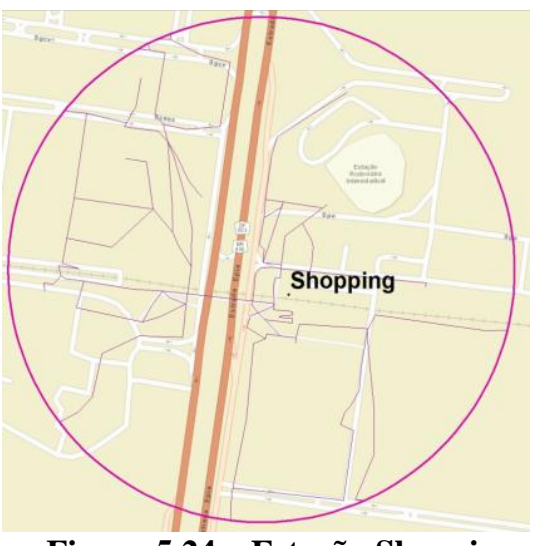

Figura 5.24 - Estação Shopping

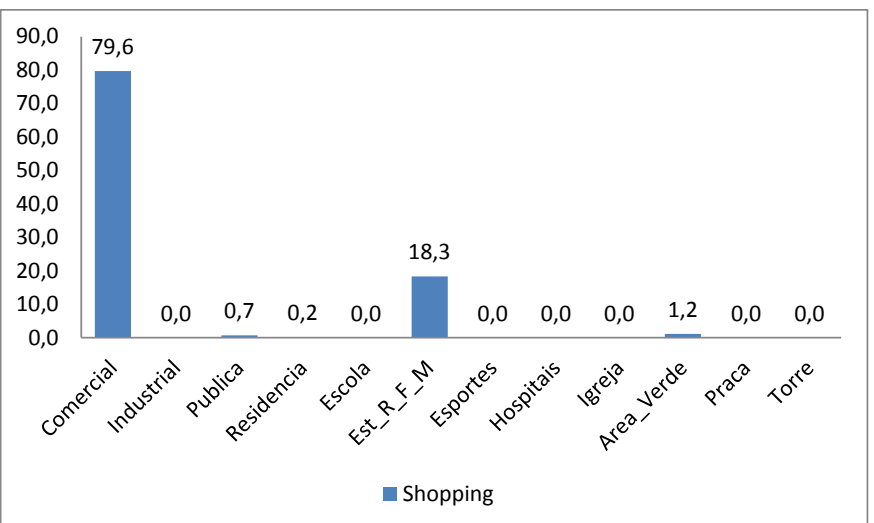

Figura 5.25 - Classificação Uso do Solo - Shopping

As Figuras 5.26 e 5.27 trazem os retratos dos caminhos que os pedestres podem seguir ao sair da estação Shopping. O diagnóstico demonstra que, ao redor da estação referida, há precariedade de informações disponibilizadas aos pedestres, retirando deles a autonomia de escolha de rotas e o planejamento de viagem, bem como desfavorecendo a apropriação do espaço por parte dos indivíduos. 


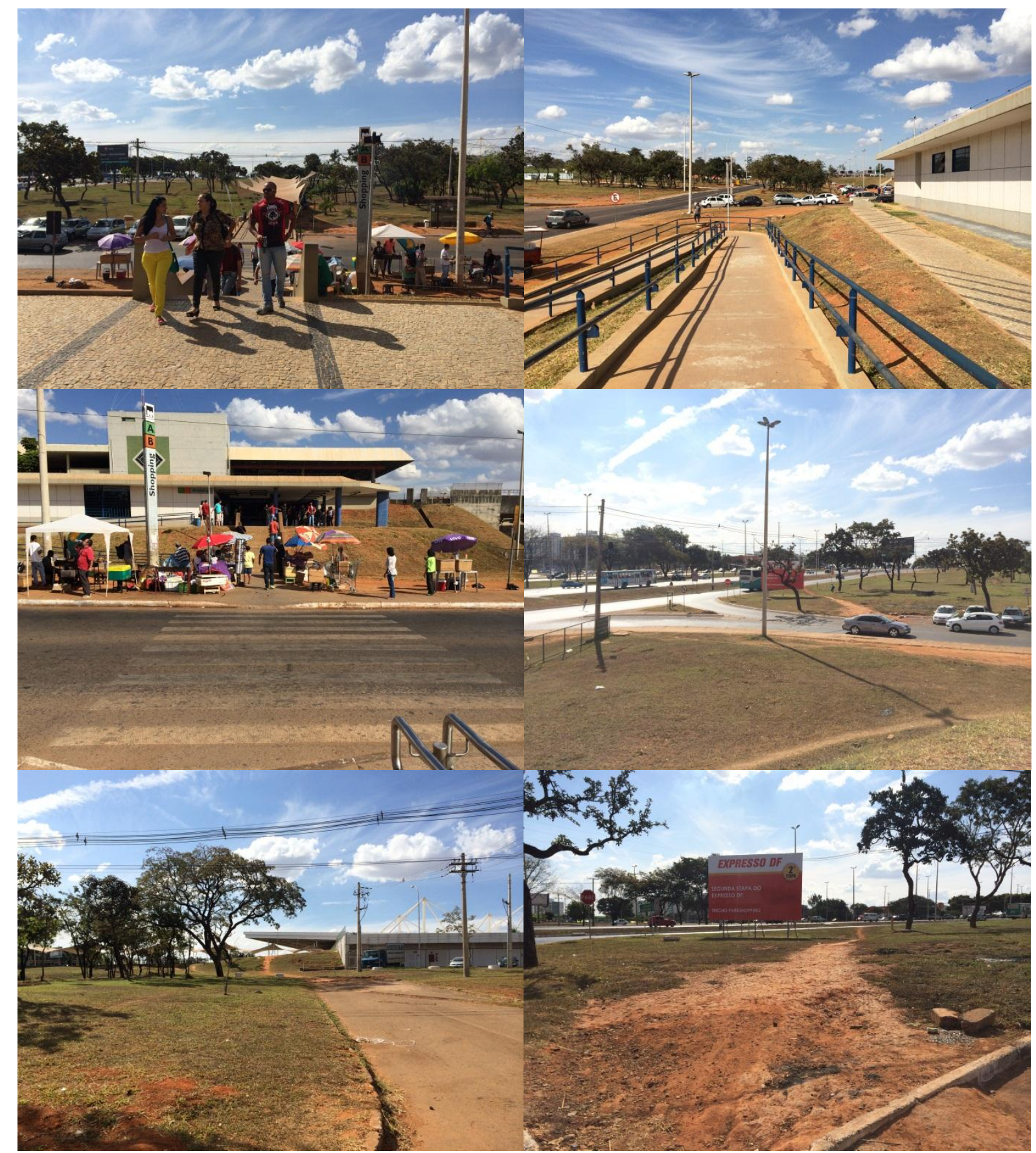

Figura 5.26 - Area de Influência estação Shopping 


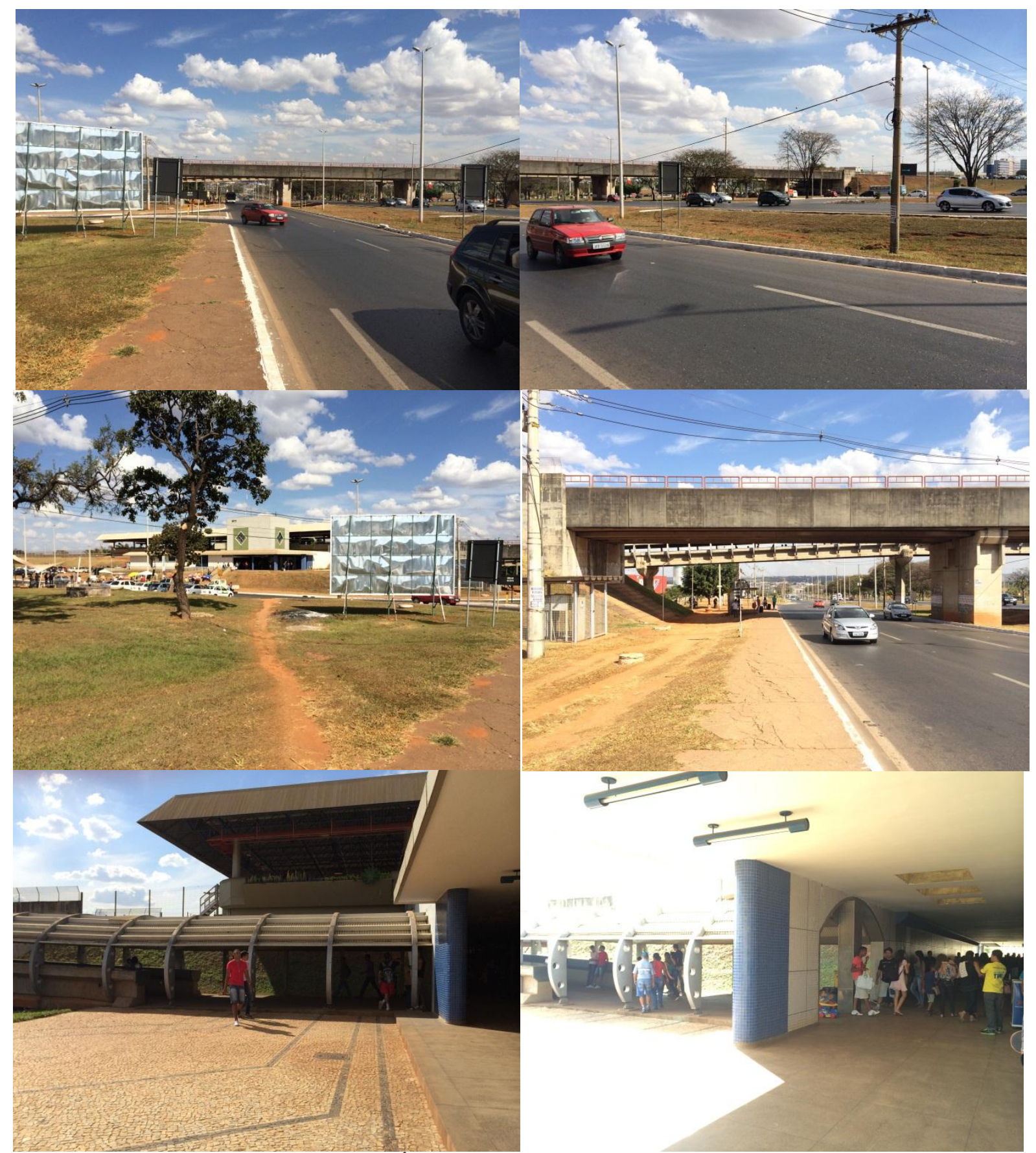

Figura 5.27 - Área de Influência estação Shopping

3) Guará

A estação Guará localiza-se na Região Administrativa do Guará, em área tipicamente urbana, compreendida entre o Guará I e o Guará II. A disposição das quadras no Guará I segue um padrão, compondo uma série de quadriláteros. O Guará II é formado, em sua maioria, por grandes quadras residenciais em formato quadrangular. A cidade é um importante polo de 
desenvolvimento econômico do Distrito Federal. Assim como exposto na estação Shopping, ao redor desta estação há precariedade de informações. A Figura 5.28 traz a área de influência da estação e os caminhos/rotas de pedestres traçados. A Figura 5.29 mostra o percentual do uso de solo para a área construída no raio de 500 metros.

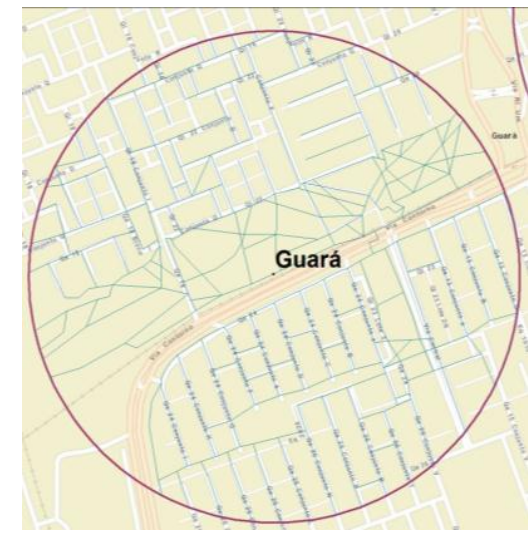

Figura 5.28 - Estação do Guará

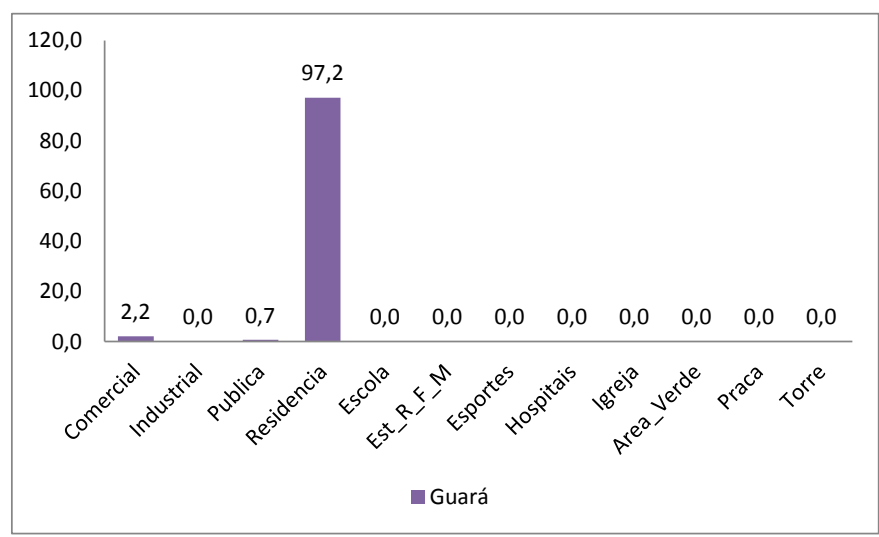

Figura 5.29 - Classificação do Uso do Solo - Guará

A Figura 5.30 mostra os caminhos que os pedestres podem seguir ao sair da estação Guará. O diagnóstico ao redor da estação indica a precariedade de informações disponibilizadas aos pedestres.
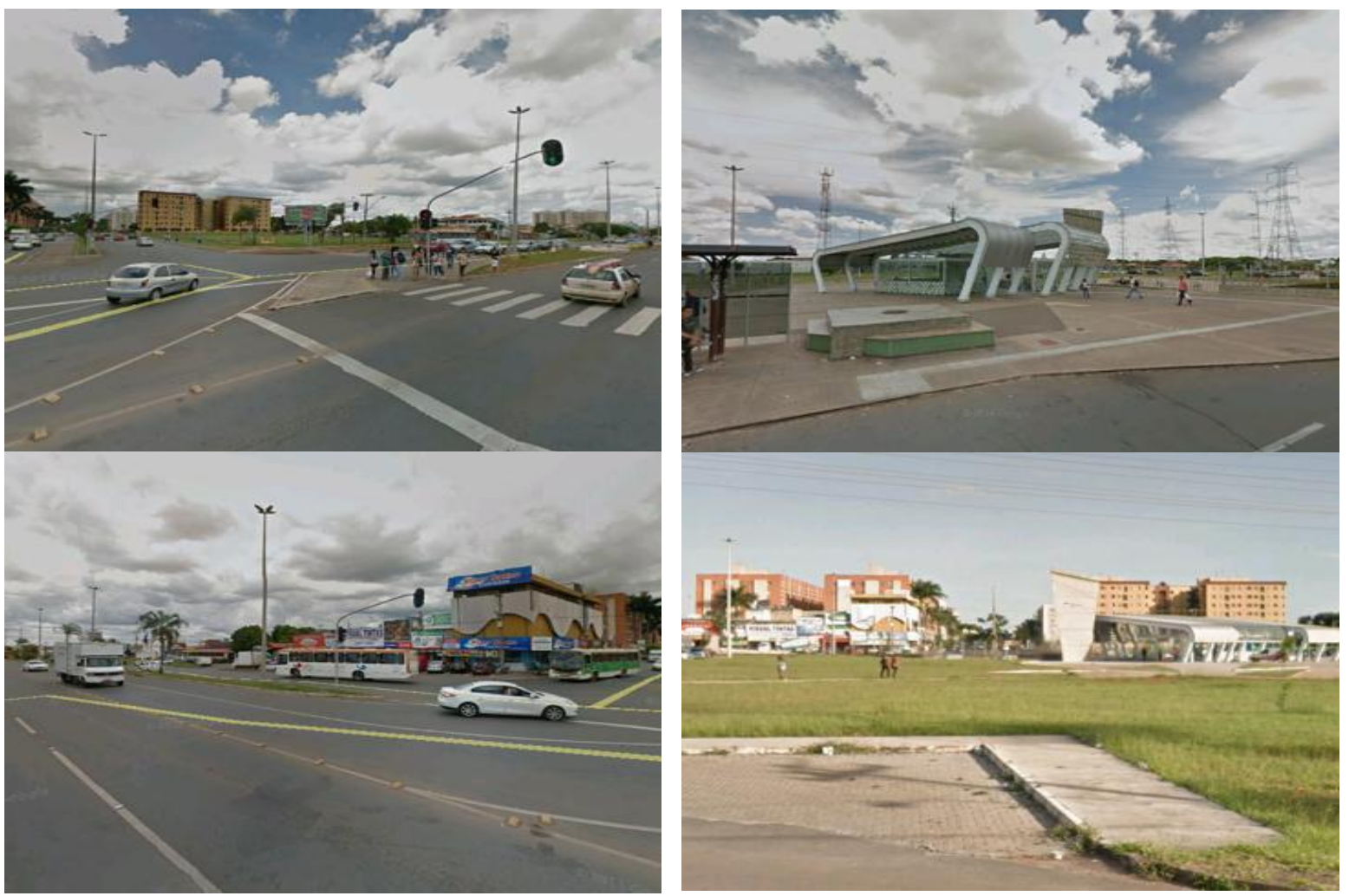

Figura 5.30 - Área de Influência da estação Guará 
4) Praça do Relógio

A estação Praça do Relógio localiza-se no bairro de Taguatinga, a cerca de 19 (dezenove) quilômetros de Brasília. A região desenvolveu-se especialmente em função do comércio e da renda de quem trabalha no Plano Piloto. É importante centro comercial dentro do Distrito Federal e polo de atração para a população das cidades próximas, além de possuir shoppings centers de grande porte. . A Figura 5.31 traz a área de influência da estação e os caminhos/rotas de pedestres traçados. A Figura 5.32 mostra o percentual do uso de solo para a área construída no raio de 500 metros.
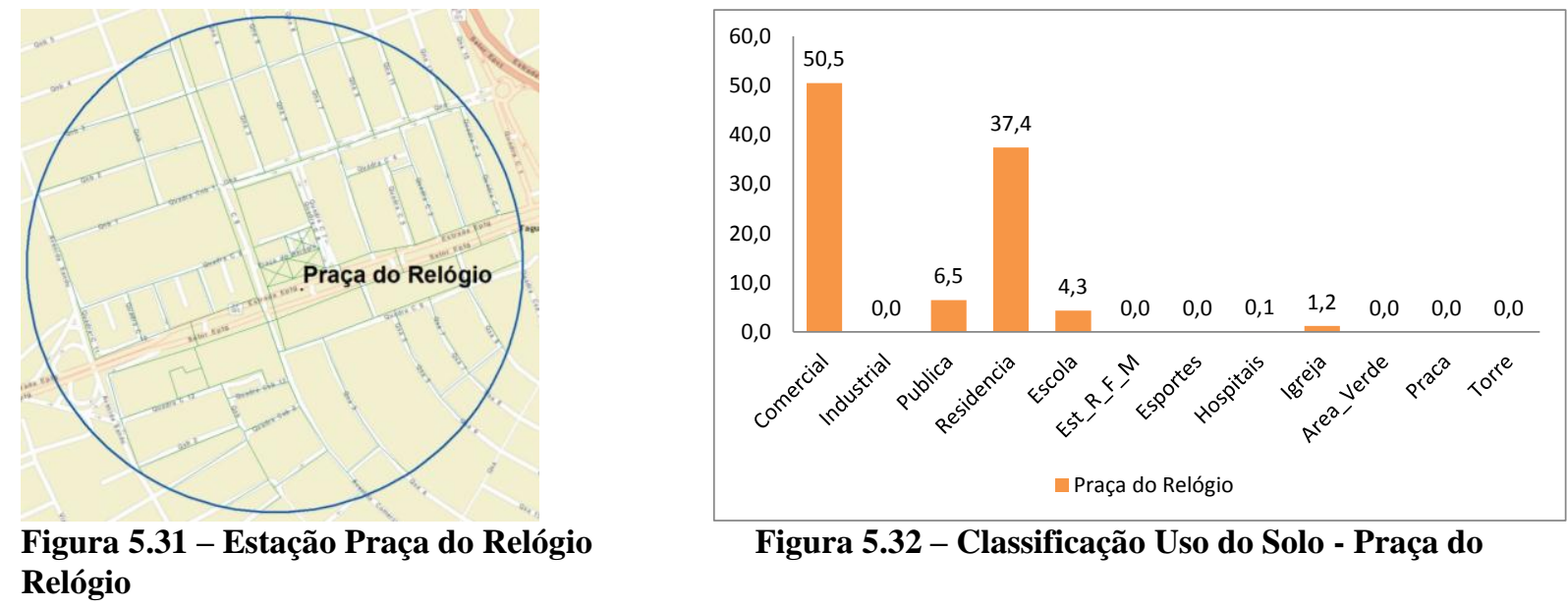

Figura 5.32 - Classificação Uso do Solo - Praça do

A Figura 5.33 traz os retratos dos caminhos que os pedestres podem seguir ao sair da estação Praça do Relógio. O diagnóstico mostra que, ao redor da estação, há precariedade de informações. 


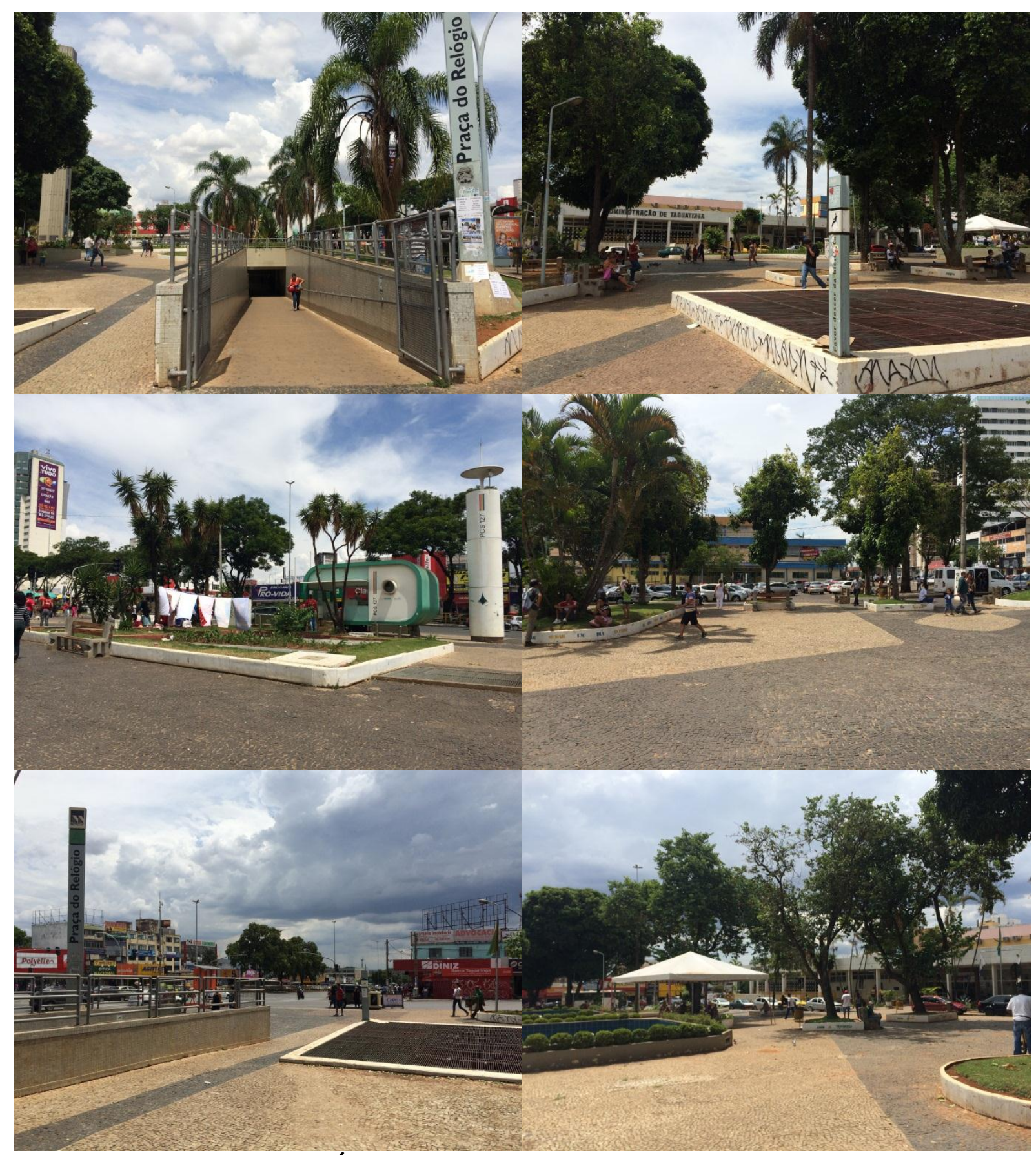

Figura 5.33 - Área de Influência da estação Praça do Relógio 
5) Furnas

A estação Furnas localiza-se na Região Administrativa de Samambaia. Samambaia também foi criada por lei em 1989, sendo sua construção uma tentativa de o governo solucionar o problema das diversas famílias oriundas de invasões, vindas de todas as partes do país para o Distrito Federal. A Figura 5.34 traz a área de influência da estação e os caminhos/rotas de pedestres traçados. A Figura 5.35 mostra o percentual do uso de solo para a área construída no raio de 500 metros.

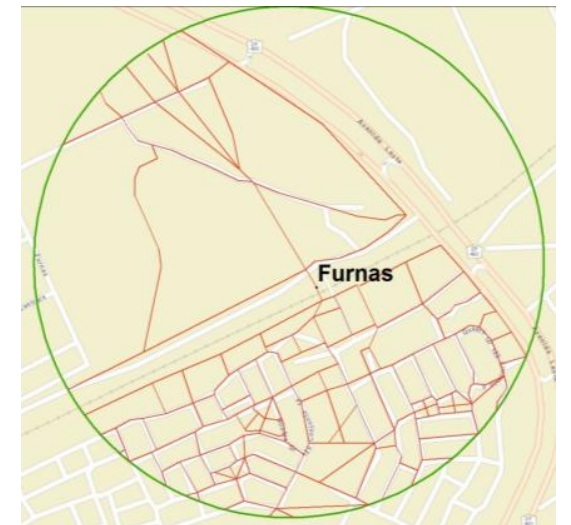

Figura 5.34 - Estação Furnas

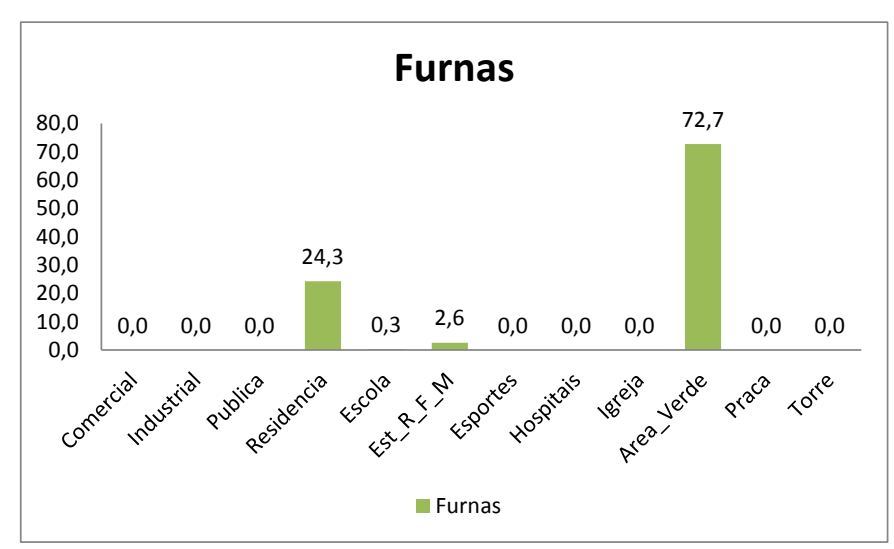

Figura 5.35 - Classificação do Uso do Solo - Furnas

A Figura 5.36 traz os retratos dos caminhos que os pedestres podem seguir ao sair da estação Furnas. O diagnóstico mostra que, ao redor da estação, há precariedade de informações. 

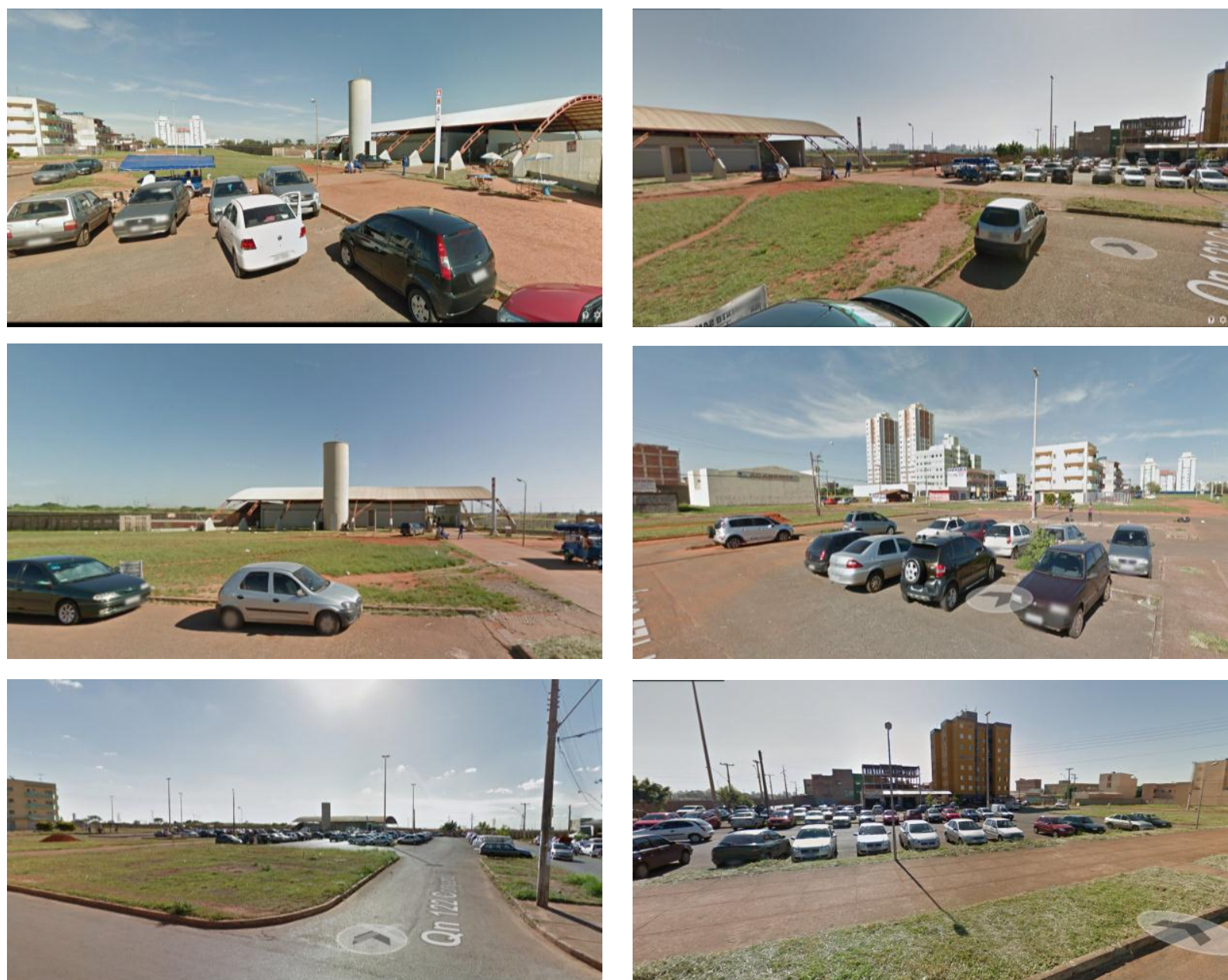

Figura 5.36 - Área de Influência da estação Furnas

\subsubsection{Obtenção das Isócronas das Estações escolhidas}

A obtenção das isócronas das estações foi um passo metodológico necessário adotado para o objetivo do presente estudo. Contudo, após a localização da estação do metrô, foi criada uma rede de transporte simples para os deslocamentos de pedestres aos arredores da via, e calculada as isócronas (assumindo a velocidade de $4 \mathrm{~km} / \mathrm{h}$ ) para os tempos de 5, 10 e 15 minutos. As isócronas geradas na Figura 5.37 representam um alcance máximo de deslocamento realizado por um pedestre, bem como a construção do modelo para a análise dos resultados ( $4^{\mathrm{a}}$ fase - verificar as áreas com maior visibilidade ao pedestre) apresentada no próximo capítulo. 

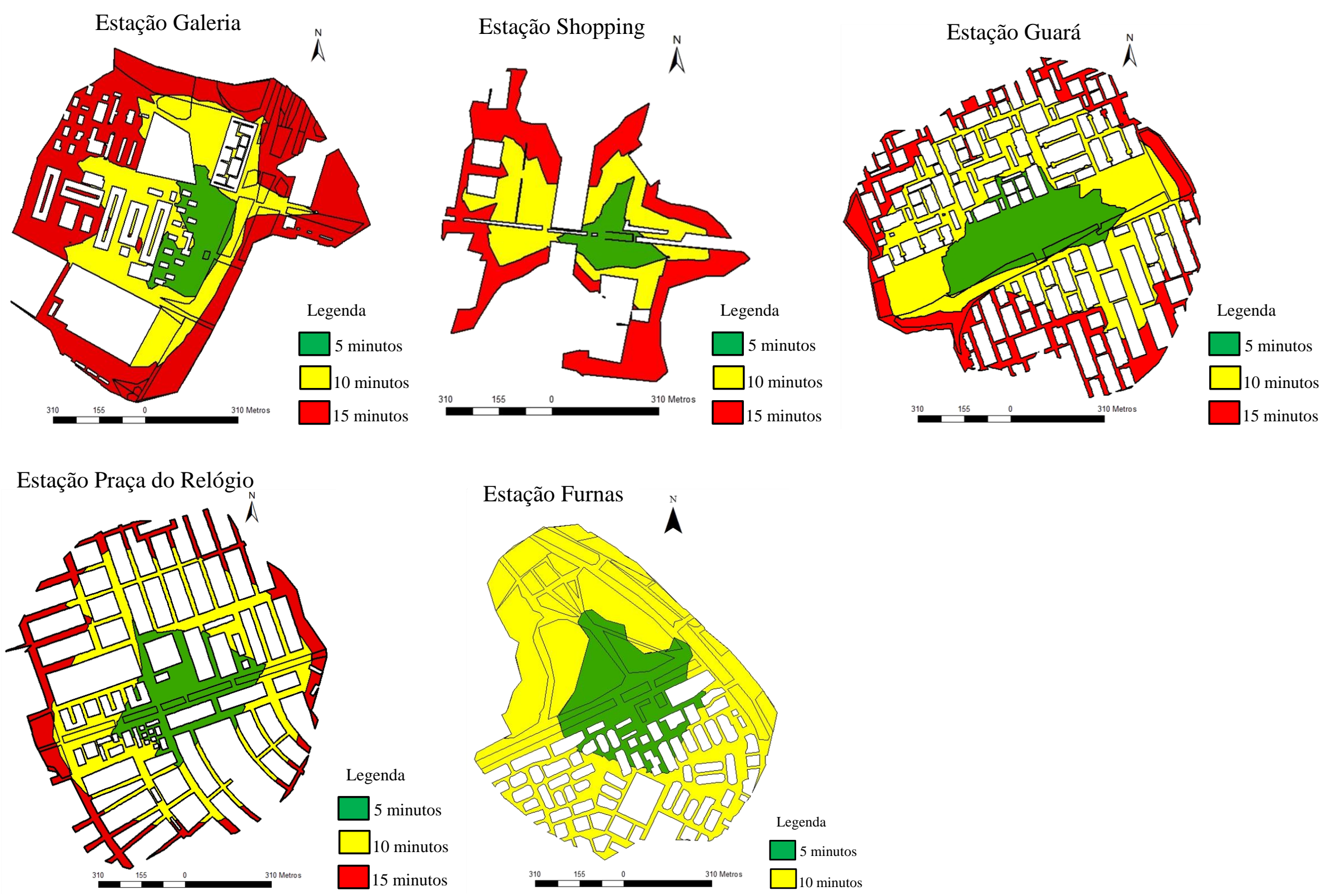

Figura 5.37 - Isócronas (5, 10 e 15 minutos) na área de influência das estações 


\subsection{TÓPICOS CONCLUSIVOS}

Mediante as escolhas e os diagnósticos das áreas de influências das estações, foi possível obter as isócronas com os três tempos estabelecidos (5, 10 e 15 minutos) e assim partir para a construção do modelo para a análise dos resultados, que será a $4^{\mathrm{a}}$ fase (verificar as áreas com maior visibilidade ao pedestre) apresentada no próximo capítulo. 


\section{ANÁLISE DE RESULTADOS}

\subsection{APRESENTAÇÃO}

A análise do estudo tem natureza qualitativa e compreende a interpretação gráfica dos resultados oriundos da aplicação da Teoria da Lógica Social do Espaço ou Sintaxe Espacial. Investigam-se as áreas que apresentam melhor adequação para receberem informações de sinalização para o pedestre. A partir da Sintaxe do Espaço, exploram-se quais locais seriam potencialmente mais vantajosos para abrigarem indicações aos pedestres. A abordagem visa à identificação de como a forma urbana, por si só, é capaz de contribuir para apontar esses locais, o que se associa à configuração dos lugares em primeira instância, a afetar inclusive o planejamento e o uso do solo (o que inclui aspectos de circulação e transportes). Os capítulos 2 e 3 discorreram sobre os conceitos, as teorias e as ferramentas que subsidiam essa estratégia de leitura do espaço, baseada na relação dos cheios e vazios do espaço que podem fomentar ou limitar o deslocamento dos pedestres. Os principais elementos fornecidos para a análise e que contribuem para a maneira de apreensão das informações pelos indivíduos foram apresentados no capítulo 2, conforme mostra a Tabela 6.4:

Tabela 6.4 - Principais elementos exposto pelos autores

\begin{tabular}{l|l|l}
\hline \multicolumn{1}{c|}{ Autor } & \multicolumn{2}{c}{ Elementos } \\
\hline Jane Jacobs & Interação-Relação & Diversidade \\
\hline Kelvin Lynch & Legibilidade & Referência-Orientação \\
\hline Jan Gehl & Escala Humana \\
\hline
\end{tabular}

Para a interpretação dos estudos de caso, as ferramentas de leitura da Sintaxe do Espaço requerem a decodificação do sistema em suas barreiras (cheios, que não podem ser vistos e/ou percorridos) e permeabilidades (vazios, que podem ser visto e/ou percorridos). Significa que a base para a interpretação está nos vazios que se relacionam e, em princípio, configuram a rede de caminhos e espaços que podem livremente ser atravessados. Vale lembrar que quando a área analisada incluir grandes vazios passíveis de circulação, ou seja, não apresentar nenhuma barreira, para maior refinamento do estudo será procedida uma ponderação metodológica, conforme relatado no item 5.2 - Restrição de aplicação do método - capítulo 5. 
Importa reforçar que a análise procedida na pesquisa é realizada em três escalas de aproximação a partir das estações selecionadas como pontos de origem. Consideram-se os trechos percorríveis pelos pedestres, a partir das estações, em 5, 10 e 15 minutos, o que resulta numa leitura que segue do âmbito mais local para a mais global. De acordo com os aspectos apontados no capítulo 5, as variáveis escolhidas são:

- Área da Isovista - indica as posições no espaço (agrupáveis em zonas) que apresentam os campos de visão $\left(360^{\circ}\right)$ maiores em um determinado sistema de análise (área efetiva);

- Raio Máximo da Isovista: indica os pontos a partir dos quais o pedestre possui um campo de visão de maior alcance linear. A variável não está relacionada à área de efetiva visibilidade, mas sim ao raio de abrangência das posições no espaço o que, de certa maneira, pode contribuir para a identificação de caminhos preferenciais de deslocamento a partir de uma rede de posições no espaço de maior alcance; e

- Integração Visual: indica pontos que são visualmente mais integrados, isto é, que podem mais facilmente ser alcançados a partir de todos os demais do sistema; significa encontrar as localizações preferenciais para, por exemplo, a disposição de totens informativos.

Desta forma, o método para localização espacial de unidades de informações enfatiza o cumprimento dos três objetivos específicos apresentados no primeiro capítulo: $i$ ) analisar o desempenho configuracional das áreas de influência das estações; $i i)$ identificar os pontos de melhor localização de unidades de informações aos pedestres; iii) aplicar o método nas estações de transporte público de Brasília (Metrô). A seguir serão apresentadas as cinco estações estudadas.

\subsection{AS ESTAÇÕES DO METRO NO ESPAÇO URBANO}

Como cumprimento do primeiro objetivo específico, as cinco estações escolhidas para o estudo foram classificadas conforme capítulo 5, item 5.4.1 (Tabela 5.2), por englobarem diferentes áreas de uso do solo e por apresentarem um maior fluxo de passageiros, item 5.4.1 (Tabela 5.3). Em primeiro lugar, foi considerado o valor da área construída dentro do raio de 500 metros e, depois, foi levado em consideração o fluxo médio de passageiros, conforme expressa a Tabela 6.5 . 
Tabela 6.5 - Classificação quanto ao uso de solo das áreas de influência das estações

\begin{tabular}{l|l|c}
\multicolumn{1}{c|}{ Estação } & \multicolumn{1}{c|}{ Uso do Solo } & Fluxo - Media Mensal de Passageiros \\
\hline Galeria & Comercial e pública & 221.067 \\
\hline Shopping & Predominantemente comercial & 258.352 \\
\hline Guará & Predominantemente residencial & 162.641 \\
\hline Praça do Relógio & Comercial e residencial & 277.132 \\
\hline Furnas & Áreas verdes e residencial & 132.034 \\
\hline
\end{tabular}

A aplicação do método (terceiro objetivo específico) decorreu em Brasília - Distrito Federal. A capital, além da setorização funcional, apresenta uma especificidade na ruptura da escala urbana, pois os grandes espaços vazios (concepção modernista de cidade) aumentaram significativamente o tempo de deslocamento a pé em trajetos que em outras cidades não costumam ser tão extensos. Devido ao considerável tempo para se deslocar a pé na cidade, encontrar um método que forneça informações em pontos estratégicos colaboraria com a continuidade e orientabilidade do pedestre nos espaços urbanos (segundo objetivo específico).

\subsection{ANÁLISE GERAL DAS VARIÁVEIS}

Em relação às análises das variáveis oriundas da Sintaxe Espacial, para as cinco estações, nos três recortes espaço-temporal de análise (5, 10 e 15 minutos), foram obtidos os resultados relatados a seguir. As análises foram realizadas do espaço-temporal global (15 minutos) para o local (5 minutos), com o objetivo de se verificar nos três tempos e com as três variáveis a possível sobreposição dos campos com maior visibilidade, construindo locais prioritários para o fornecimento de informações. Cabe esclarecer que a estação Furnas apresenta uma particularidade nos espaços-temporais, pois a área de influência comportou o deslocamento a pé de até 10 minutos, ou seja, o tempo máximo percorrido para atingir a distância de 500 metros a partir da estação é de 10 minutos e não de 15 minutos como acontece nas outras 4 estações estudadas.

\subsection{1 Área das isovistas}

São os campos com isovistas maiores, ou seja, são os lugares que as pessoas utilizam, tradicionalmente, como referências de navegação. 
Nas estações Shopping (Figuras 6.38, 6.39 e 6.40) e Furnas (Figuras 6.46 e 6.47) os campos com maior visibilidade estão próximos à saída e à entrada da estação do metrô, formando um corredor central. Especificamente na estação Shopping, que tem o segundo maior fluxo de passageiros das cinco estações estudadas, por exibir um único caminho (passarela) para atravessamento da via EPIA, os campos com maior visibilidade coincidem com a entrada e a saída da passarela. A estação Furnas, por apresentar na sua área de influência a predominância de área verde com aproximadamente $73 \%$ de uso, formou um corredor central na via local que conecta a estação as residências. Já na estação Guará, após ponderação metodológica, devido ao grande espaço vazio na sua área de influência, foi constatado que os campos com isovistas maiores são as entradas e/ou saídas das ruas locais que permitem acesso à estação. Pelo levantamento do uso do solo, a estação Guará apresenta $97 \%$ de uso residencial, e a disposição das quadras segue um formato de quadriláteros no Guará I e um formato quadrangular no Guará II, justificando os campos de maior visibilidade nas entradas e/ou saídas das ruas que ligam a estação conforme mostram as Figuras 6.43, 6.44 e 6.45. 
Os gráficos ilustram os tempos e as variáveis escolhidas, sempre levando em consideração o deslocamento realizado em minutos pelos pedestres. Estação Shopping

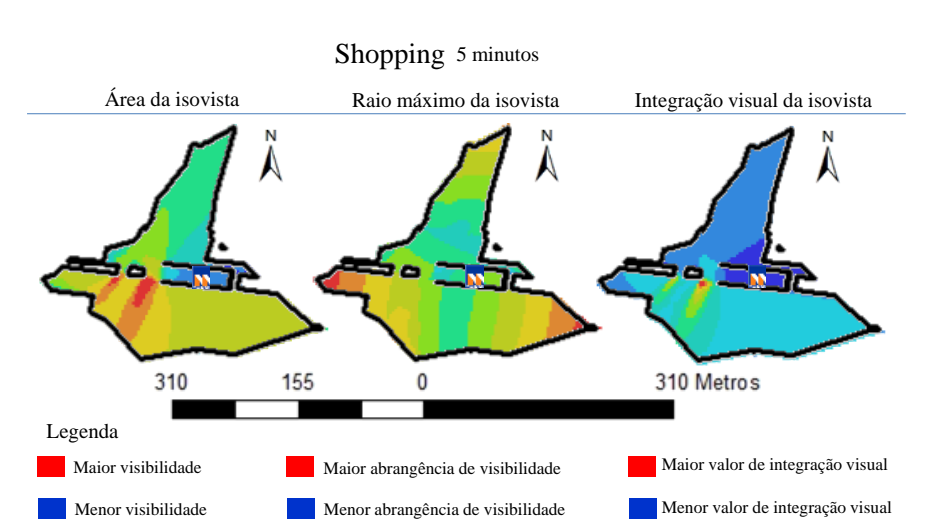

Figura 6.38 - Shopping_variáveis em 5 minutos

Shopping 15 minutos

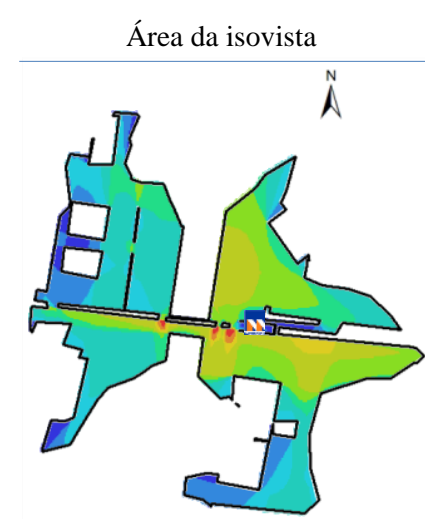

Raio máximo da isovista

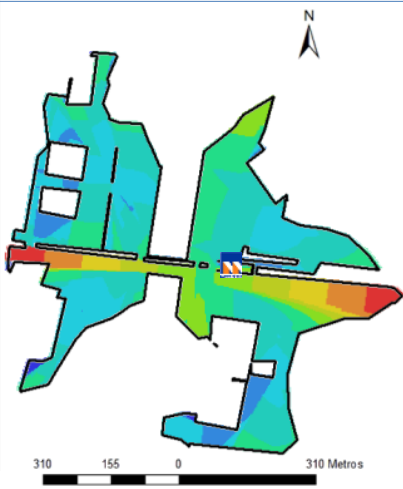

Legenda

Maior visibilidade

Maior abrangência de visibilidade

Menor visibilidade

Menor abrangência de visibilidade

Figura 6.40 - Shopping_variáveis em 15 minutos

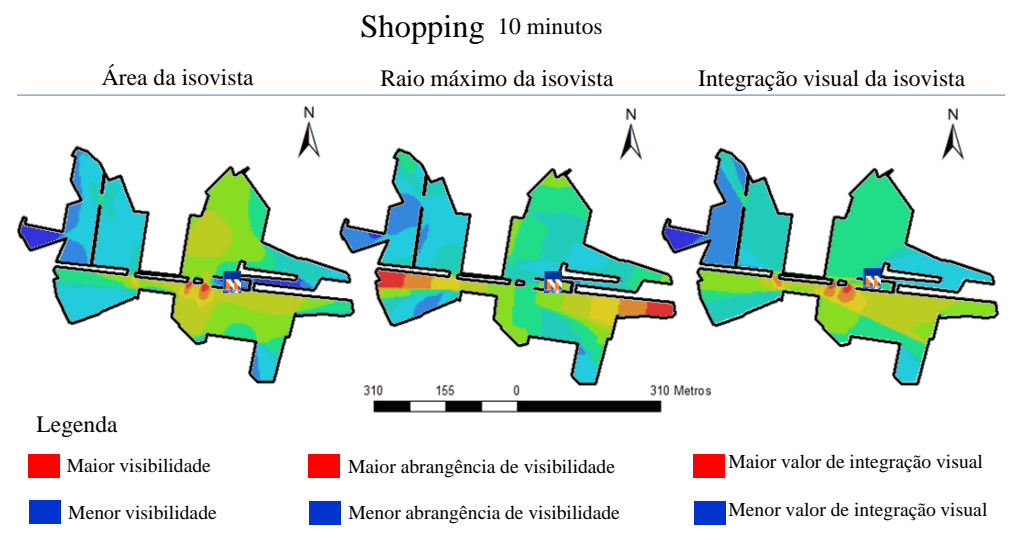

Figura 6.39 - Shopping_variáveis em 10 minutos

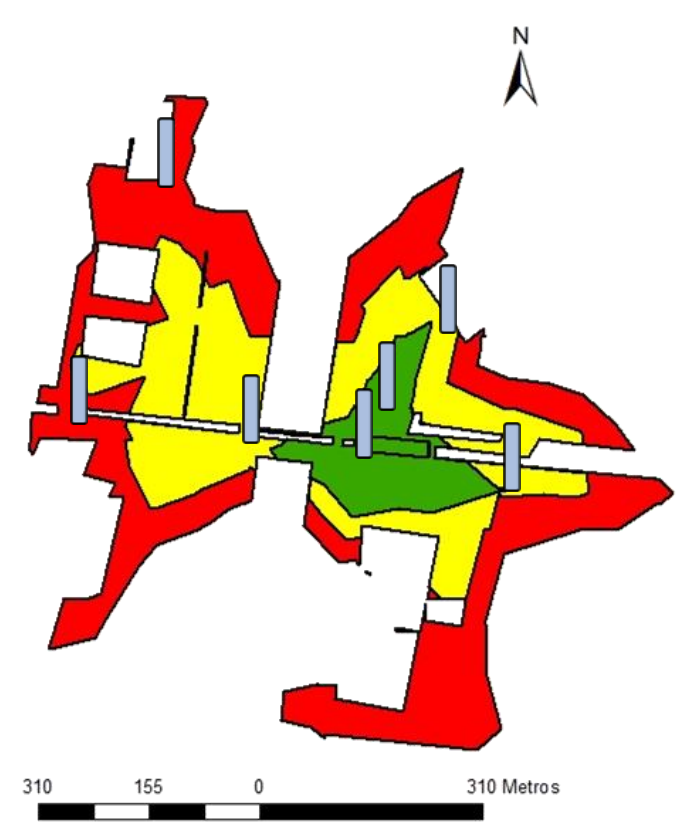

Figura 6.41 - Localização das UINP* *Unidades de informações para os pedestres 
Os gráficos ilustram os tempos e as variáveis escolhidas, sempre levando em consideração o deslocamento realizado em minutos pelos pedestres. Estação Guará

Guará 5 minutos

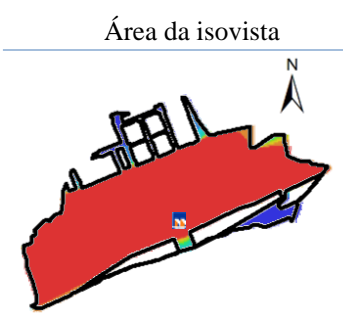

Legenda

Maior visibilidade

Menor visibilidade

Figura 6.42 - Guará_variáveis em 5 minutos

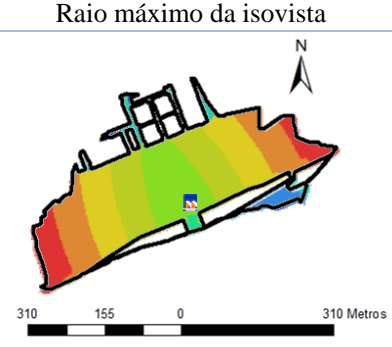

Integração visual da isovista

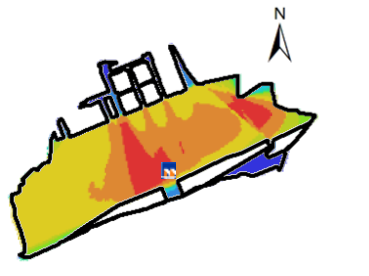

Maior valor de integração visual

Menor valor de integração visual

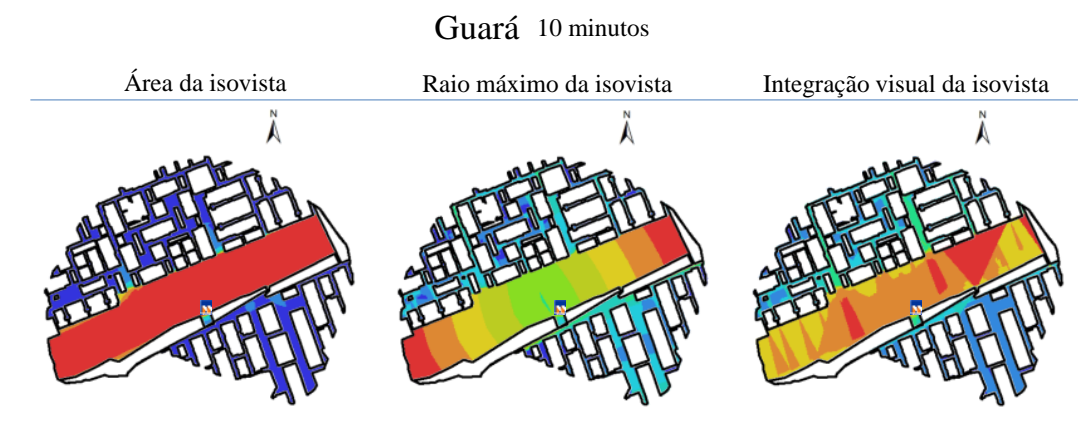

Legenda

Maior visibilidade

Menor visibilidade

Maior valor de integração visual

Menor valor de integração visual
Figura 6.43 - Guará_variáveis em 10 minutos

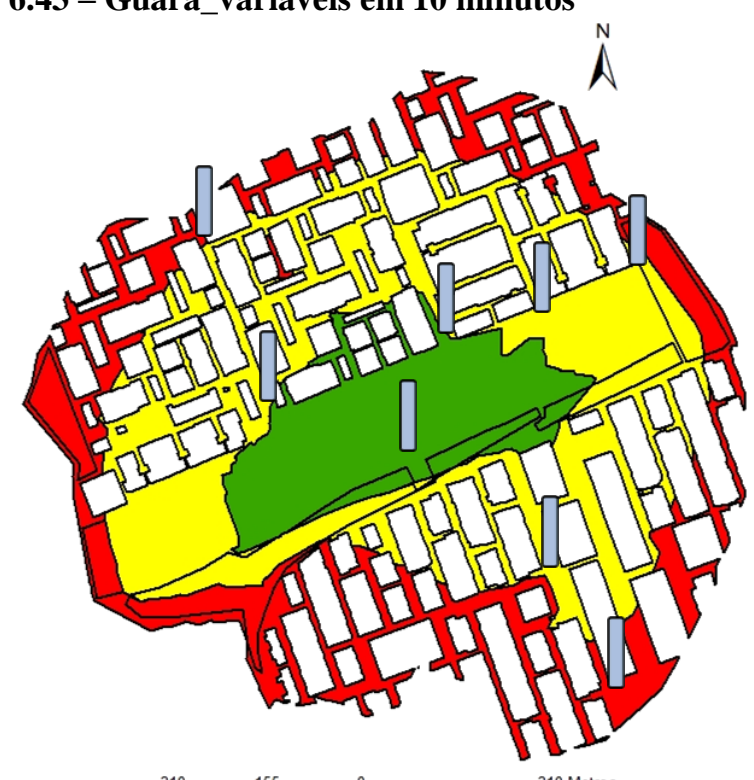

Figura 6.40 - Localização das UINP*

*Unidades de informações para os pedestres 
Os gráficos ilustram os tempos e as variáveis escolhidas, sempre levando em consideração o deslocamento realizado em minutos pelos pedestres. Estação Furnas

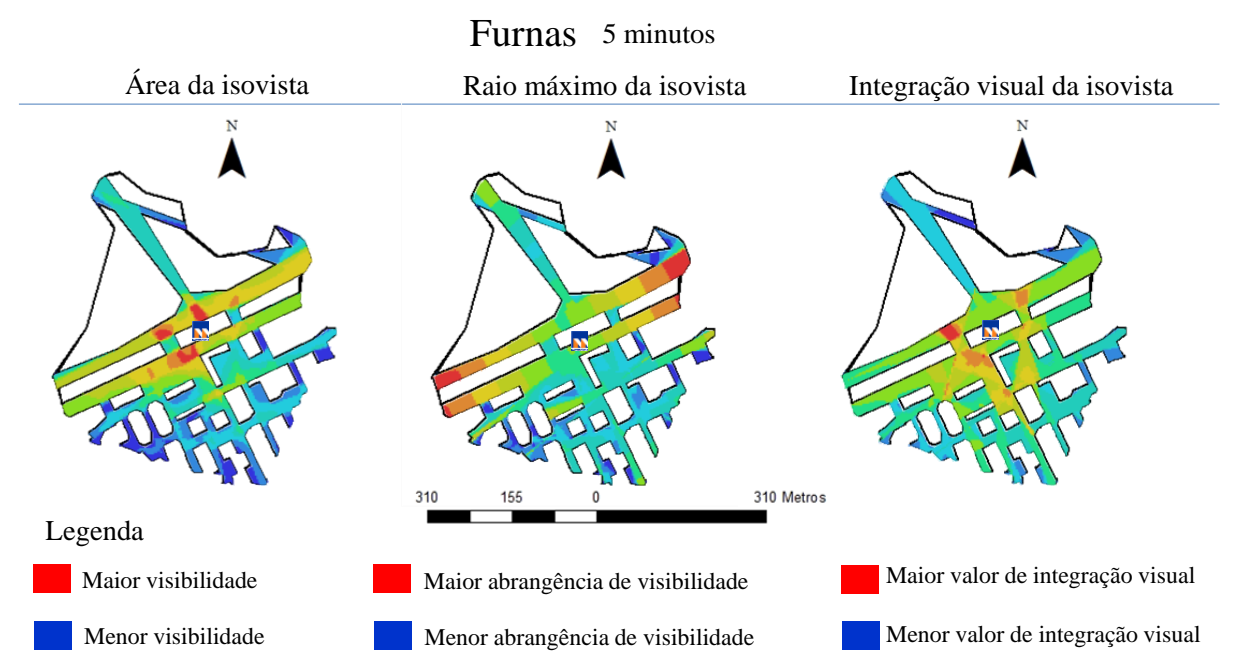

Figura 6.41 - Furnas_variáveis em 5 minutos

\section{Furnas 10 minutos}

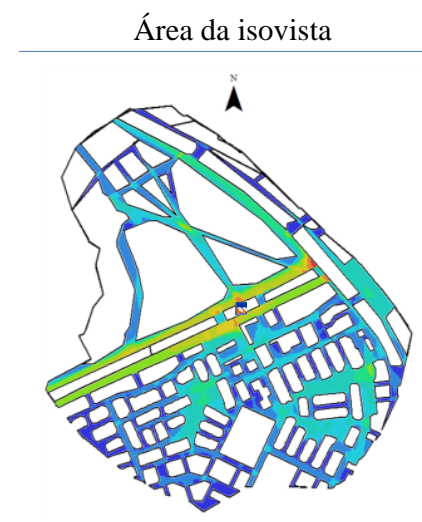

Legenda Raio máximo da isovista Integração visual da isovista

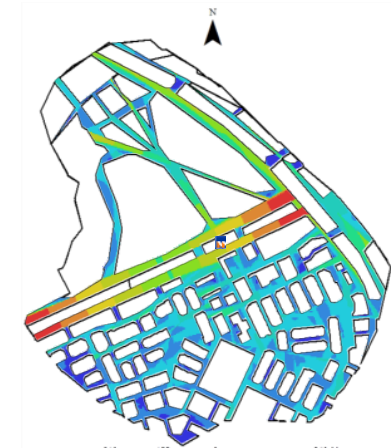

$$
\text { - }
$$

Maior visibilidade

Maior abrangência de visibilidade

Menor visibilidade

Menor abrangência de visibilidade

Figura 6.47 - Furnas_variáveis em 10 minutos
Maior valor de integração visual

Menor valor de integração visual

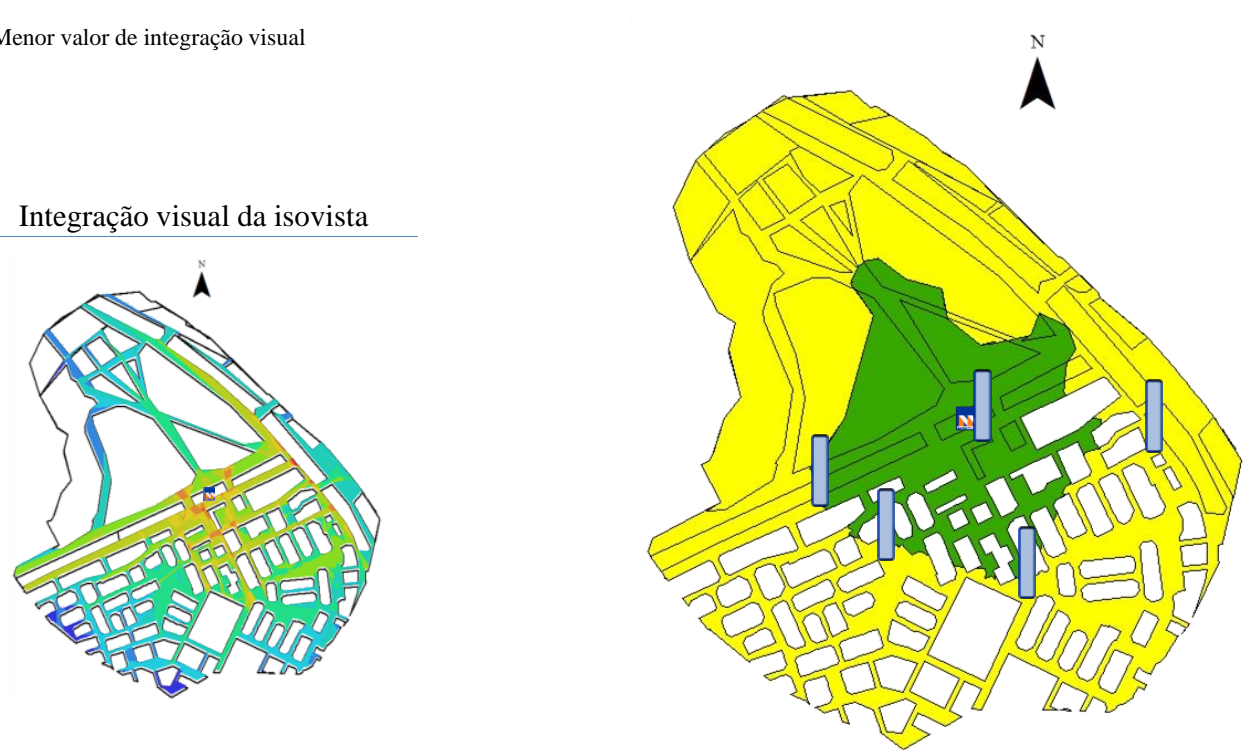

ura 6.48 - Localização das UINP*

*Unidades de informações para os pedestres 
Continuando a análise da variável área da isovista, as estações Galeria (Figuras 6.49, 6.50 e 6.51) e Praça do Relógio (Figuras 6.53, 6.54 e 6.55), indicaram corredores como os campos de maior visibilidade e, nos dois casos, principalmente as interseções da malha viária, foram decisivas para a formação desses campos visuais. O desempenho melhor para a área de isovista na estação Galeria dispõe-se entre o extremo nordeste do Setor Comercial Sul e o início do Setor de Diversões Sul, nas proximidades do CONIC. Naquele espaço, inclusive, existe uma das mais movimentadas travessias de pedestres que representa o fluxo oriundo deste o Shopping Pátio Brasil em direção à Rodoviária do Plano Piloto, indicando ser um ponto crucial para qualquer tipo de informação de orientação. Já na Praça do Relógio, os dois corredores que representam os campos com maior visibilidade estão localizados na Avenida Comercial (Norte/Sul) e na Avenida das Palmeiras. A Avenida Comercial atravessa longitudinalmente a cidade no sentido Norte-Sul, sendo comum as duas partes serem denominadas "Comercial Norte" e "Comercial Sul". Em toda sua extensão há uma diversidade de serviços e comércios, atraindo e justificando o motivo pelo qual detém o maior fluxo passageiro das cinco estações estudadas. 
Os gráficos ilustram os tempos e as variáveis escolhidas, sempre levando em consideração o deslocamento realizado em minutos pelos pedestres. Galeria

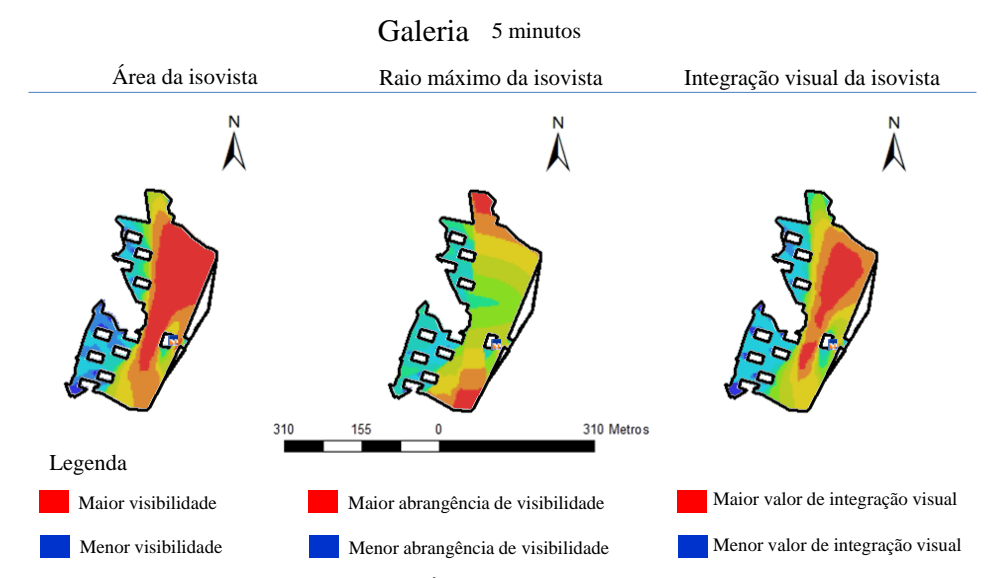

Figura 6.42 - Galeria_variáveis em 5 minutos

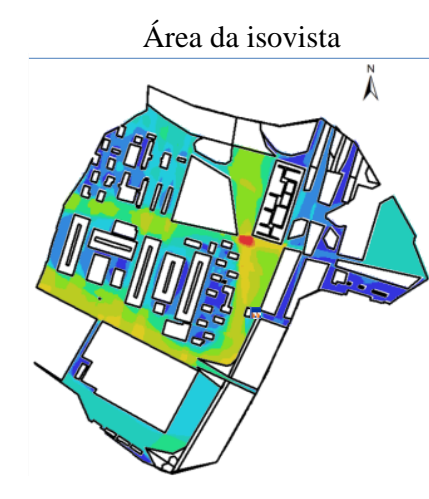

Legenda

Maior visibilidade

Menor visibilidade

Figura 6.51 - Galeria_variáveis em 15 minutos

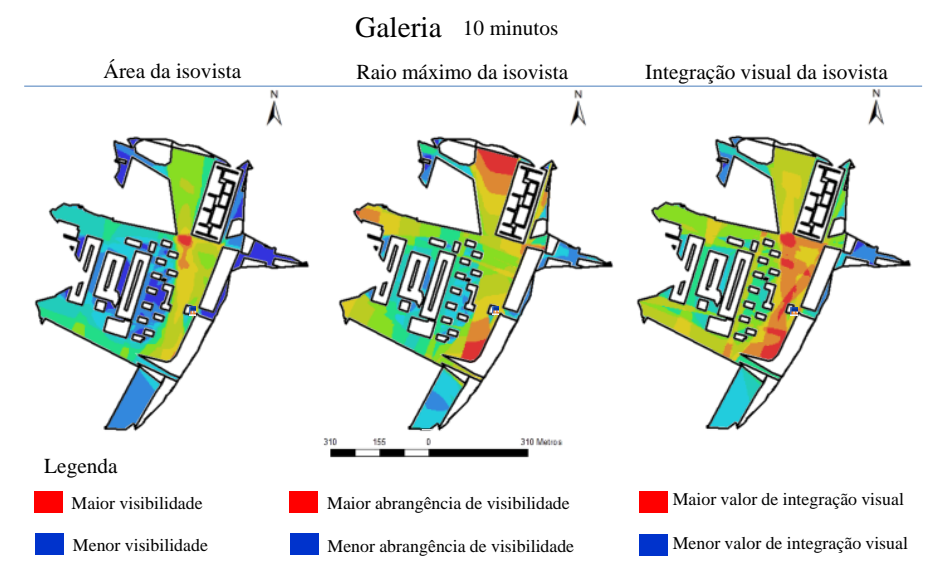

Figura 6.50 - Galeria_variáveis em 10 minutos

\section{Galeria 15 minutos}

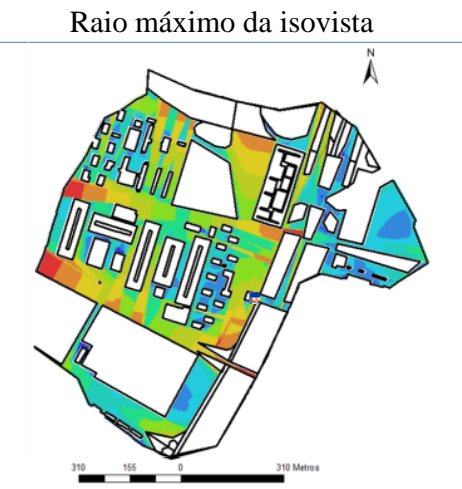

Maior abrangência de visibilidade

Menor abrangência de visibilidade Integração visual da isovista

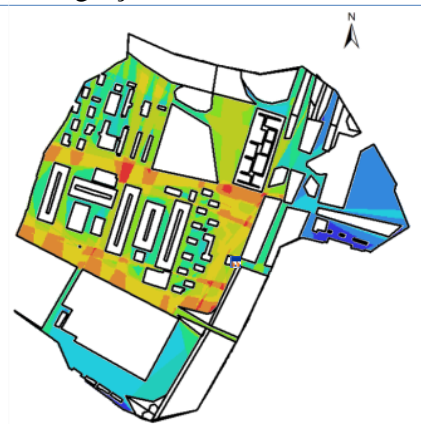

Maior valor de integração visual

Menor valor de integração visual

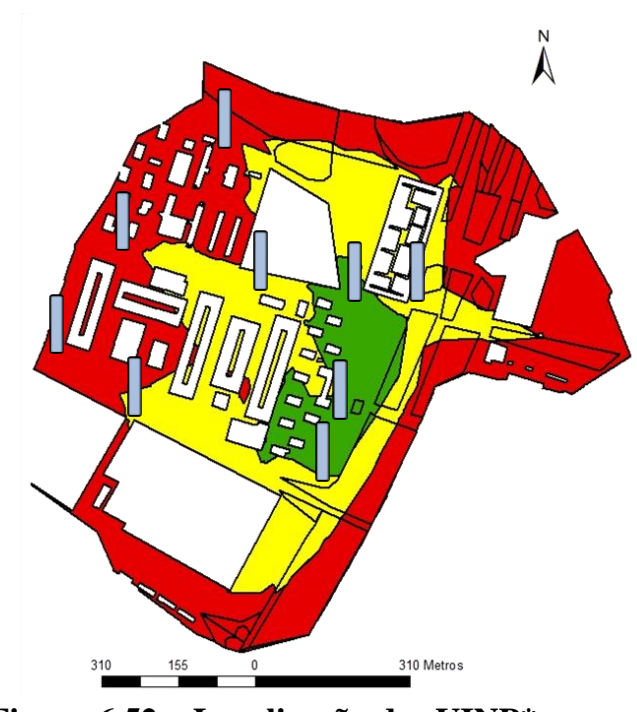

Figura 6.52 - Localização das UINP*

*Unidades de informações para os pedestres 
Os gráficos ilustram os tempos e as variáveis escolhidas, sempre levando em consideração o deslocamento realizado em minutos pelos pedestres. Praça do Relógio

Praça do Relógio 5 minutos

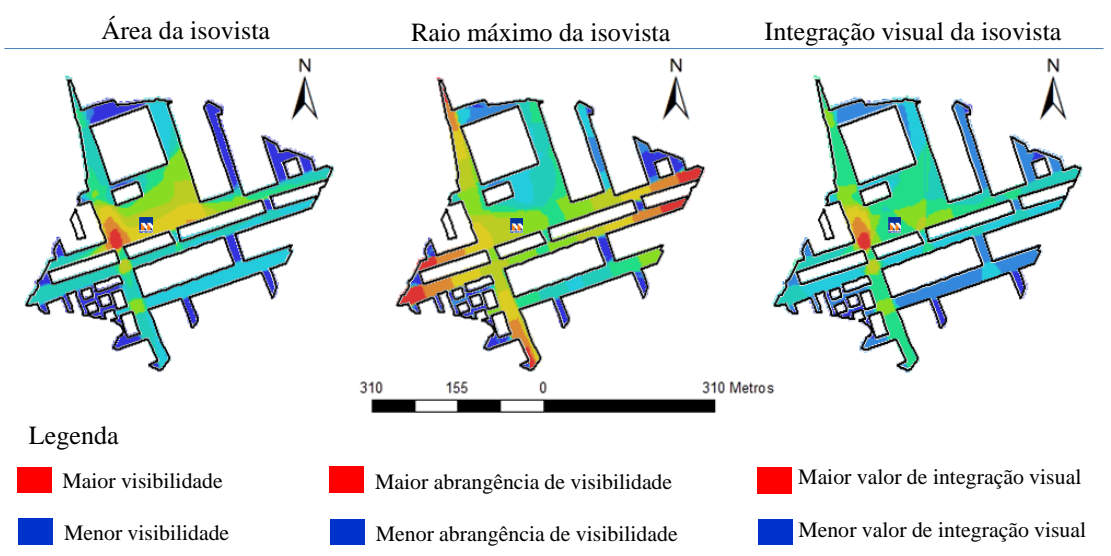

Figura 6.53 - Praça do Relógio_variáveis em 5 minutos

Praça do Relógio 15 minutos

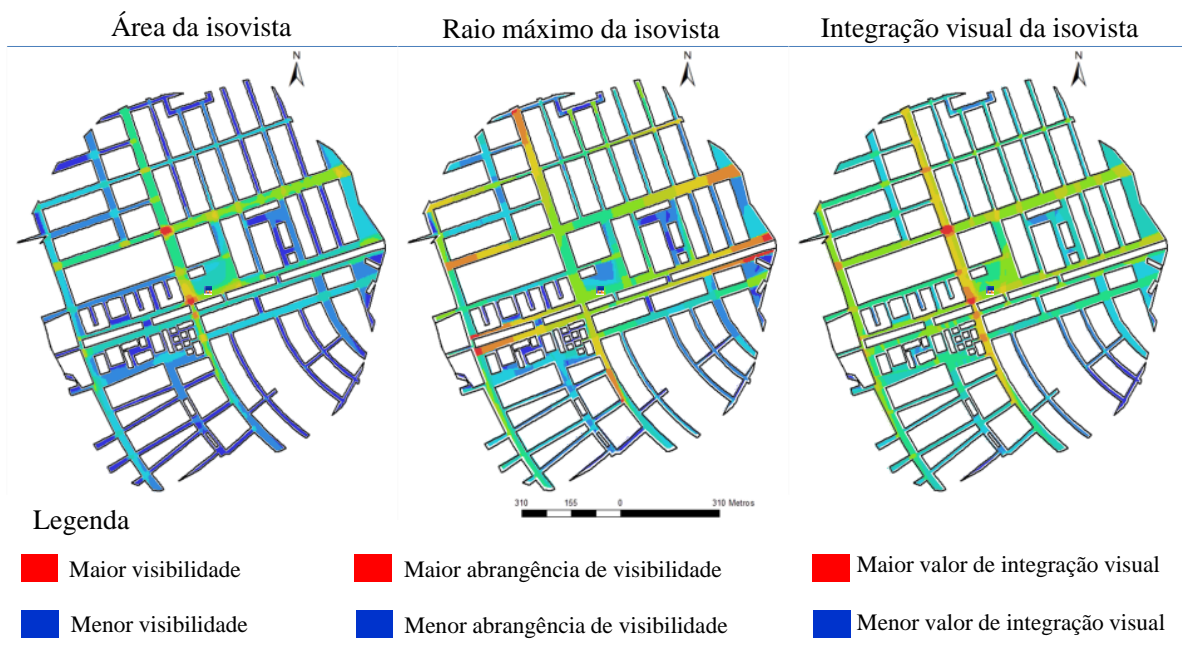

Figura 6.44 - Praça do Relógio_variáveis em 15 minutos
Praça do Relógio 10 minutos

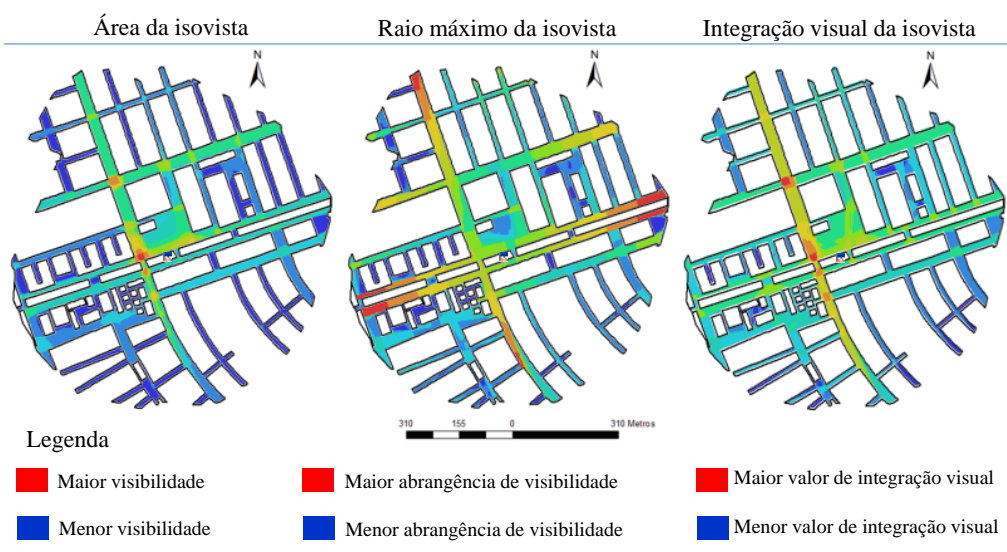

Figura 6.43 - Praça do Relógio_variáveis em 10 minutos

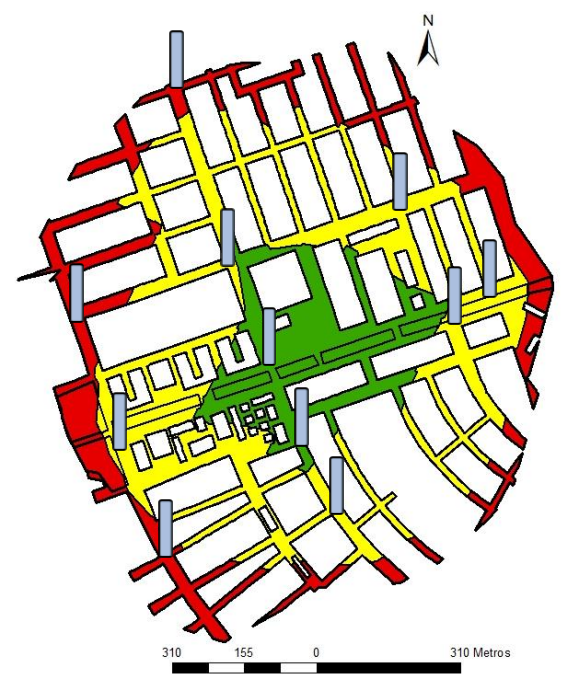

Figura 6.45 - Localizacão das UINP* *Unidades de informações para os pedestres 


\subsubsection{Raio Máximo das isovistas}

É a medida máxima de alcance de um determinado ponto.

As extremidades dos polígonos referentes às áreas de abrangência nas cinco estações estudadas assumem um valor maior para a variável, deixando claro o papel preponderante das esquinas ou dos cruzamentos nas estações Galeria e Praça do Relógio, e o domínio dos campos com menor impedância visual nas estações Shopping, Guará e Furnas. Foi possível perceber como os cruzamentos reforçam a questão da abrangência visual maior e devem prioritariamente receber informações para a clareza do pedestre.

\subsubsection{Integração Visual}

São os pontos mais integrados visualmente a partir de todo o sistema.

Os pontos visualmente mais integrados em todas as estações estudadas coincidem, grosso modo, com aqueles de maior área da isovista. A especificidade dessa variável é a precisão em relação à área de isovista para os pedestres, os pontos mais integrados correspondem àqueles mais fáceis de serem vistos a partir de todo o sistema. Esses pontos serão discutidos no item a seguir.

\subsection{ANÁLISE DOS PONTOS DE INFORMAÇÕES}

A partir desses resultados, é possível distribuir, para cada área de influência, os pontos de informações que proporcionarão uma maior clareza, continuidade e orientação do espaço urbano. A ação associa-se à hipótese deste estudo que assume que as informações, quando bem localizadas, tendem a proporcionar ao pedestre mais clareza da composição do espaço, permitindo, portanto, maior apropriação do ambiente construído, o que possibilita um deslocamento continuo e orientado.

Complementarmente, as cores aplicadas em totens, além de proporcionarem maior apropriação do espaço aos pedestres, os conduzirão a possíveis caminhos/redes, favorecendo a continuidade e estabelecendo marcos visuais que promoverão um deslocamento continuo e orientado. Os trajetos, portanto, serão mais claros. Para a pesquisa, definiu-se que a cor verde representa um deslocamento de até 5 minutos, a cor amarela até 10 minutos e, finalmente, a 
cor vermelha um deslocamento até 15 minutos a partir da estação. Quanto mais perto, verde, quanto mais distante, vermelho.

Cabe esclarecer que as modelagens elaboradas a partir da Sintaxe do Espaço (isovista e medidas derivadas) não oferecem como resultado de saída caminhos, mas sim manchas ou áreas que apresentam desempenho comum - algumas delas adequadas à localização de informações em razão da abrangência visual ou proximidade. Entretanto, quando se obtém um conjunto de manchas distribuídas no espaço, é possível traçar pontos e criar caminhos/redes interligando-as numa perspectiva de articular as posições hierarquicamente mais vantajosas, estabelecendo um trajeto.

Portanto, a estratégia para a interpretação dos dados é verificar as áreas de melhor desempenho nas três variáveis indicadas - área da isovista, raio máximo da isovista e integração visual - e priorizá-las na indicação de informações aos pedestres em primeiro nível de planejamento, uma vez que esse é o foco desse estudo. Porém é importante frisar que a quantidade, a qualidade e o tipo (estático, móvel) de informação também são fundamentais para o êxito de um sistema de informação.

Três das cinco estações estudadas (Shopping, Guará e Furnas) apresentam forte segregação de uso do solo, grandes vazios que causam ruptura no tecido urbano e, portanto, tornam o atravessamento longo e/ou perigoso, gerando falta de interação e diversidade dos espaços. Estas estações se diferenciam apenas pela grande área verde circundante, sem paisagismo, expressa na estação Furnas e a pela falta de uso de solo residencial na área de influência da estação Shopping.

A estação Shopping permite acesso aos grandes empreendimentos comerciais e de serviços caracterizados, nos tempos atuais, como as centralidades contemporâneas de grandes metrópoles, ou seja, grandes shoppings, hipermercados, entre outros, que estão distribuídos ao longo da via EPIA (via arterial com velocidade máxima de $80 \mathrm{~km} / \mathrm{h}$ ). Estes equipamentos são montados para uma estrutura em que o deslocamento é desenvolvido prioritariamente pelo automóvel, o que significa ausência da escala humanizada, gerando uma série de dificuldades para o deslocamento de pedestres na área de influência da estação. Por outro lado, questões como a necessidade de uma passarela para atravessamento de uma via de alta velocidade, no 
viés de localização de informações, facilita a distribuição de informações em pontos prioritários pela existência de um caminho claro para os pedestres (Figuras 6.57 e 6.58).

Nas estações Guará (Figuras 6.59 e 6.60) e Furnas (Figura 6.61 e 6.62), pela ruptura na escala urbana, a oferta de serviços (comércio) encontra-se distante das estações. O deslocamento a pé até o comércio local é realizado com uma média de 7 a 10 minutos. Os pontos identificados para o fornecimento de informações são as interseções das ruas que ligam as residências à estação. As estações Shopping e Furnas apresentaram poucos pontos de localização de informações.

Considerando que os pontos de origens são as estações, os deslocamentos a pé nos primeiros 5 minutos, nas estações Guará e Furnas, são realizados praticamente em áreas abertas sem muita impedância, ou seja, interferência de qualquer tipo. O efeito destes locais é o desconforto gerado pela falta de atratividade, diversidade, interação ou referência no espaço público. São elementos que tornam a região, em princípio, livre e ideal para o deslocamento a pé, um ambiente de desempenho comprometido. A exemplo, o muro (impedância) que divide a área verde da área residencial, existente na estação Furnas promove a segregação de espaços. 


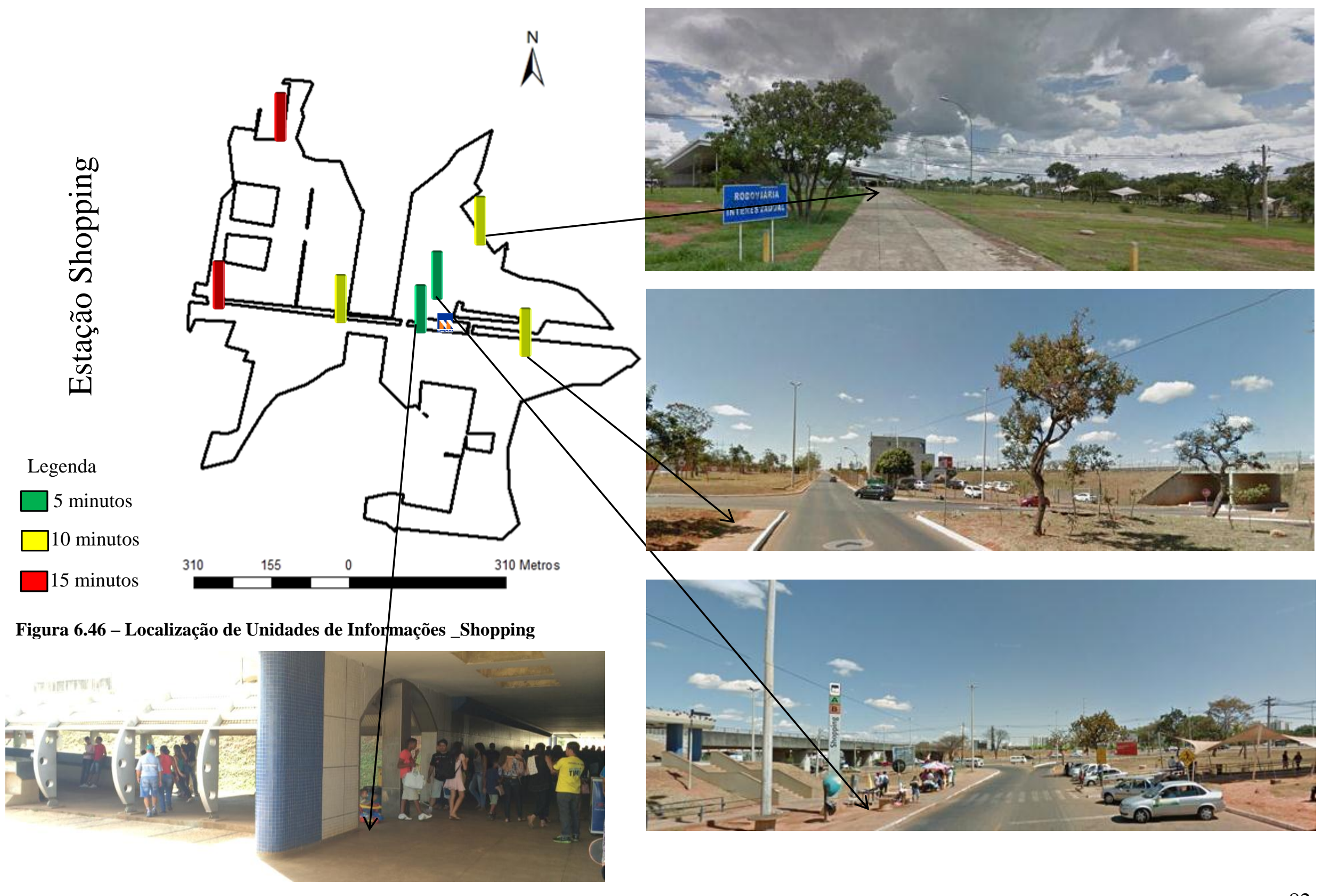



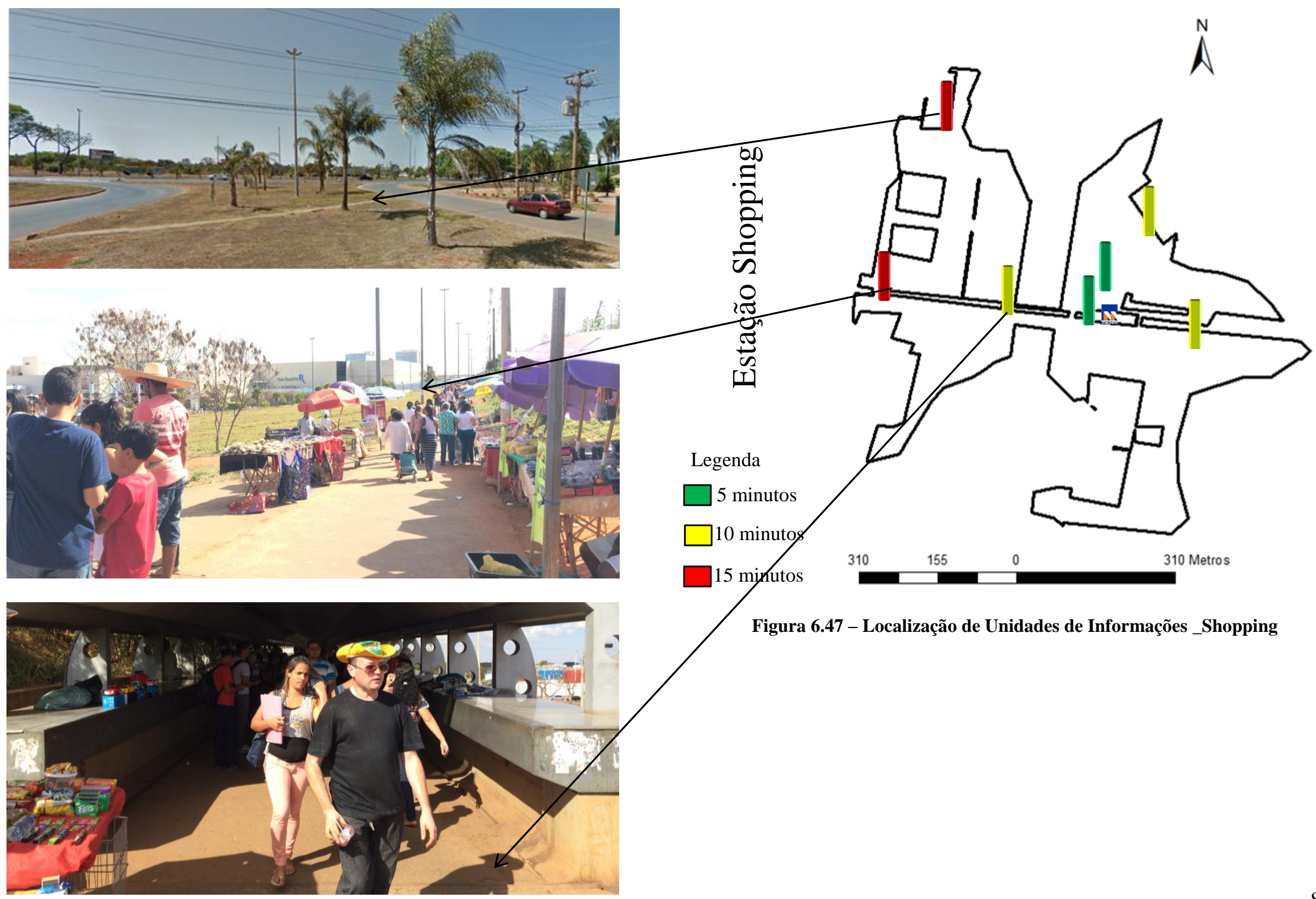

Figura 6.47 - Localização de Unidades de Informações_Shopping 


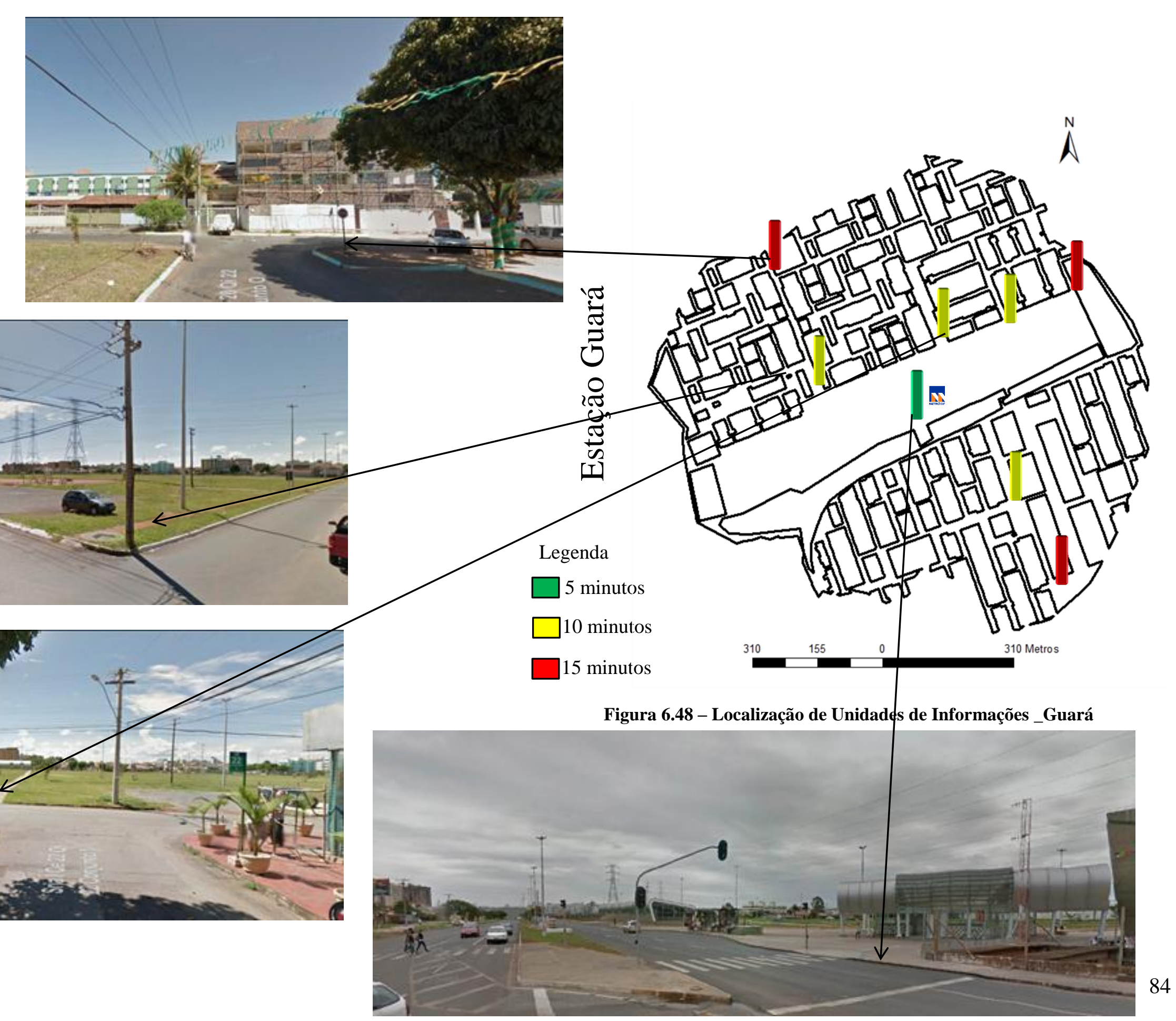




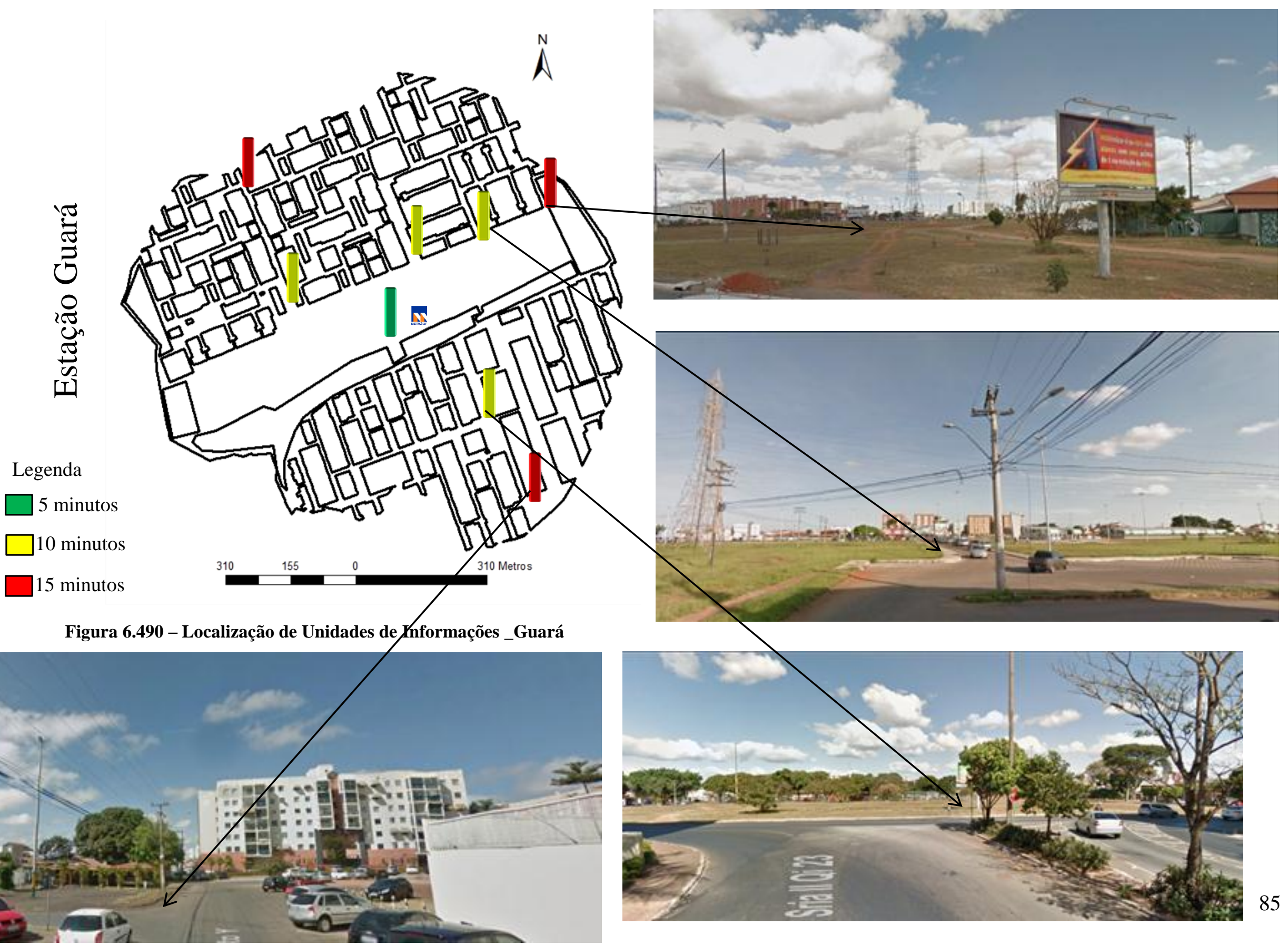




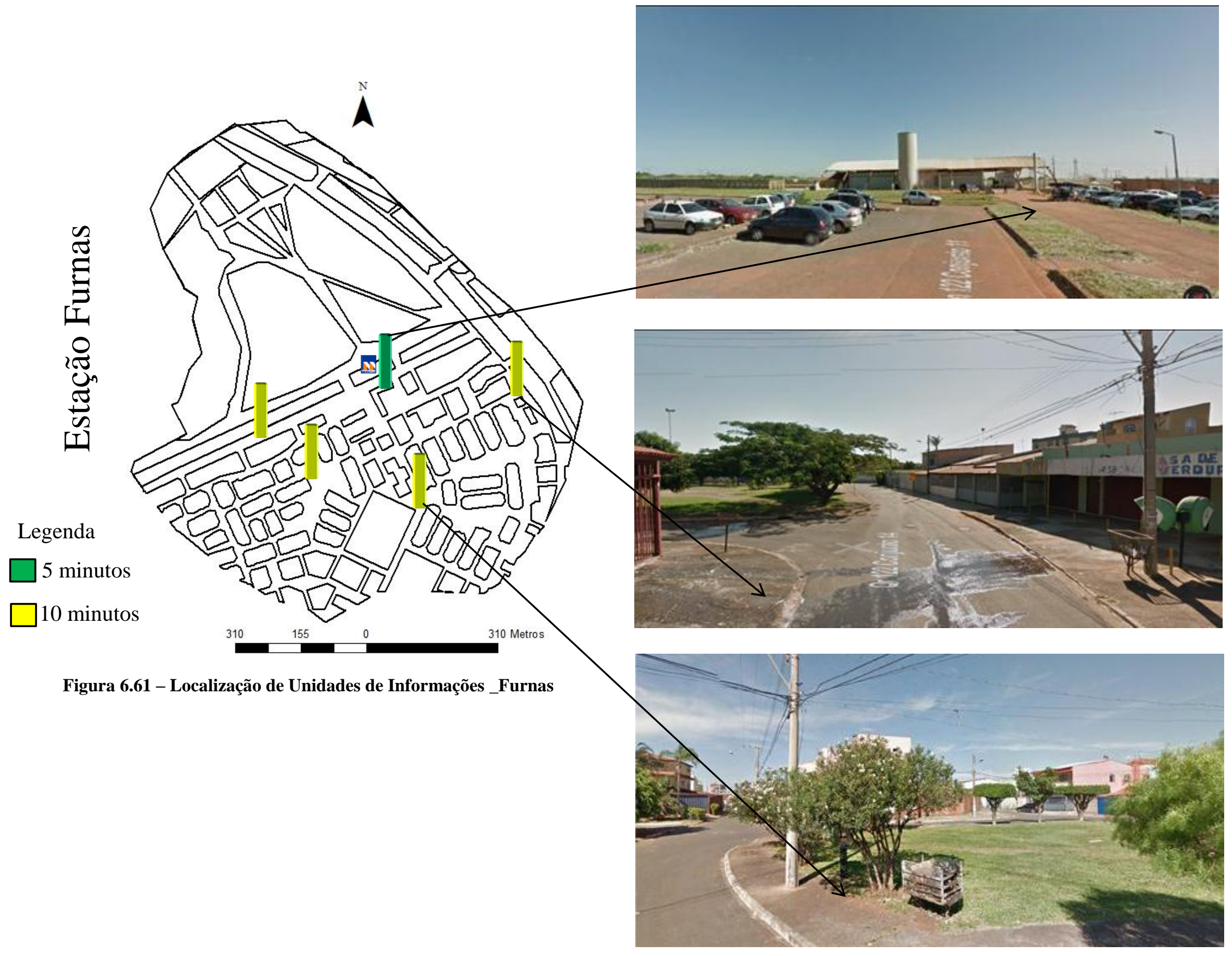




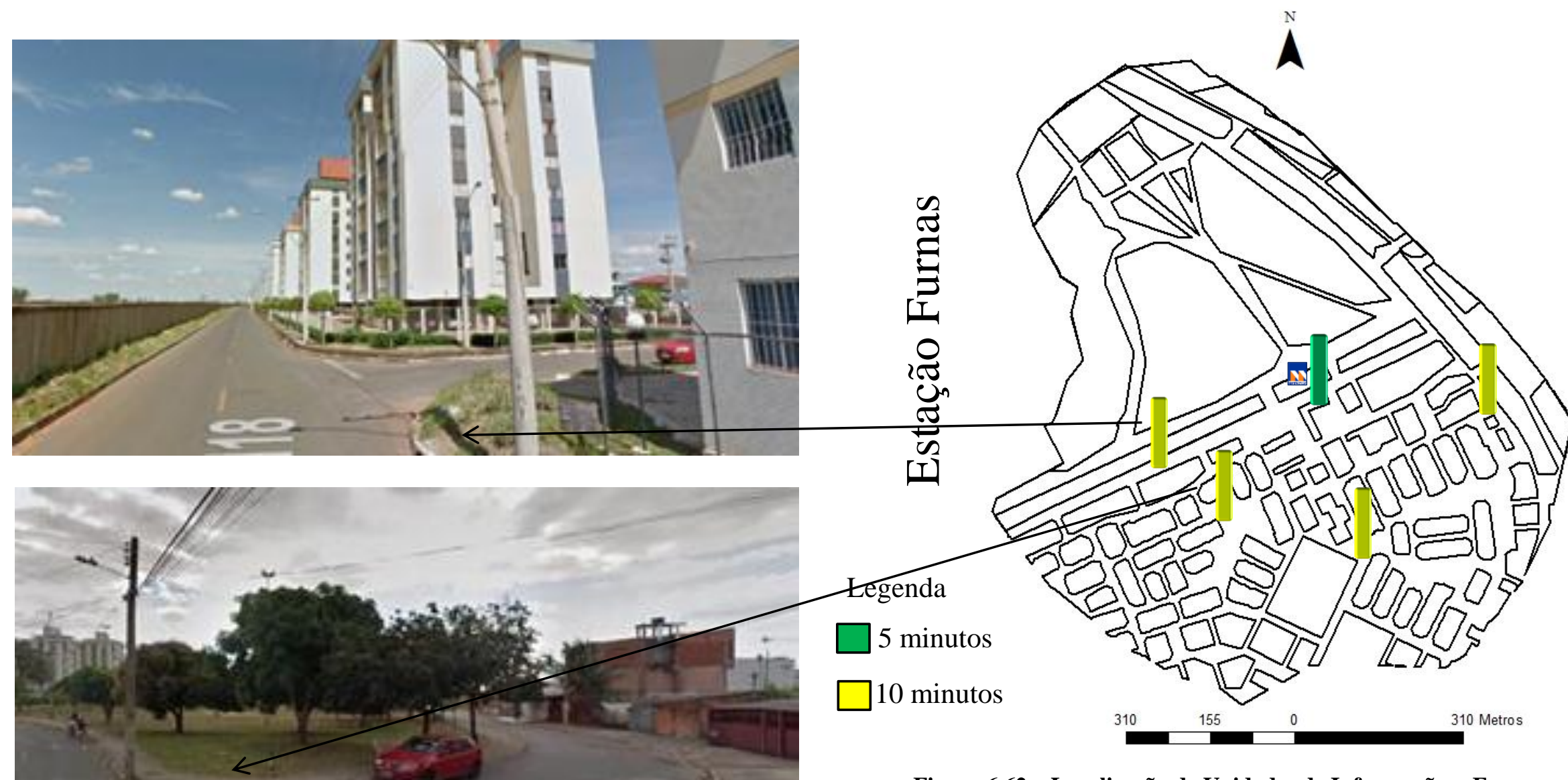

Figura 6.62 - Localização de Unidades de Informações _Furnas 
As estações Galeria (Figuras 6.63 e 6.64) e Praça do Relógio (Figuras 6.65, 6.66 e 6.67) apresentam características bastante similares entre si por contemplarem ao redor uma diversidade de serviços e comércios. Ali existem escritórios, lojas de departamento, shopping centers, clínicas e salas comerciais. Além disso, o caso da Galeria se diferencia pela concentração de diversos órgãos governamentais e um hospital regional (Hospital de Base) e, no caso da Praça do Relógio, destaca-se a existência de residências próximas. Tal diversidade de uso promove interação/relação e a grande variedade de serviços também pode representar referências visuais que ajudam a definir marcos visuais urbanos, o que define o processo de apropriação dos espaços. Para as duas estações há uma diversidade de pessoas circulando, porém não existe variedade nos horários de utilização, sendo regiões de intenso fluxo durante o horário comercial, mas predominantemente vazias à noite. Nestes dois casos, as áreas de maior visibilidade apresentadas coincidem com as áreas de maior circulação de pedestres. 


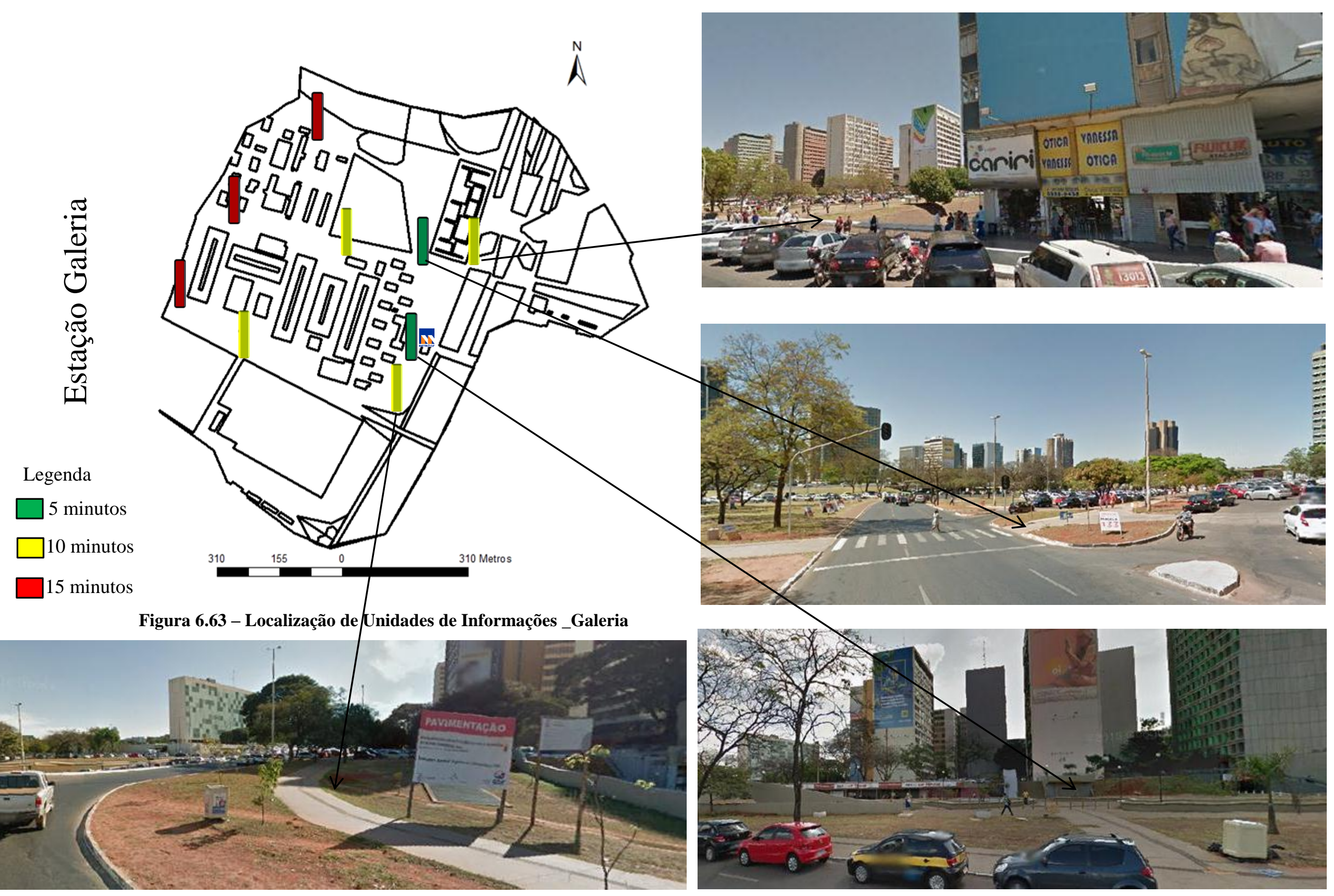



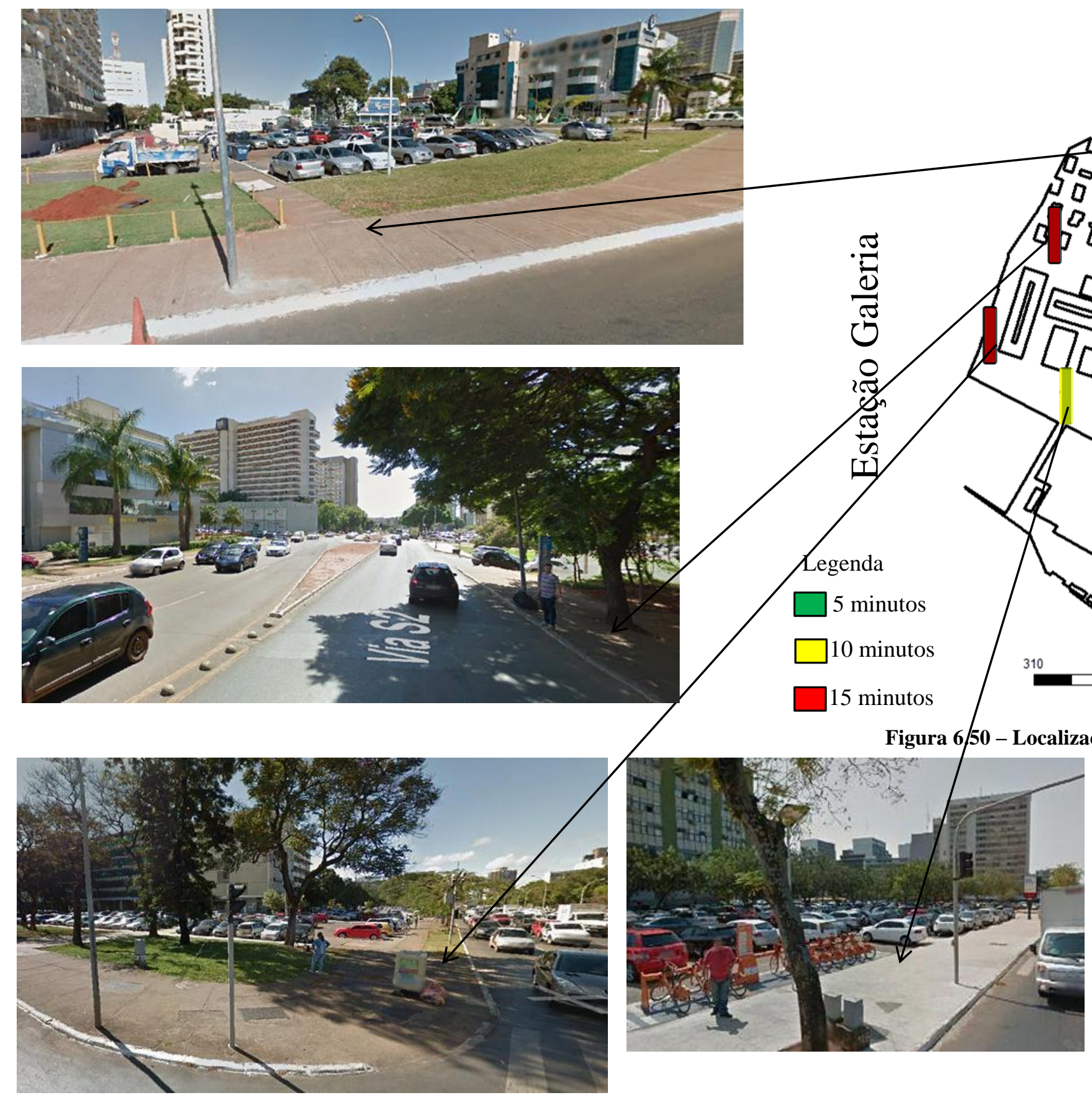

Figura $6 / 50$ - Localização de Unidades de Informações_Galeria

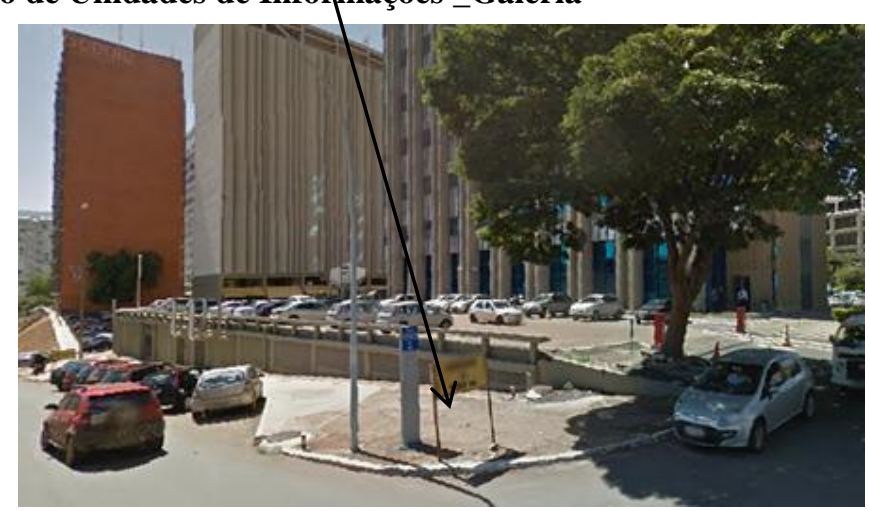




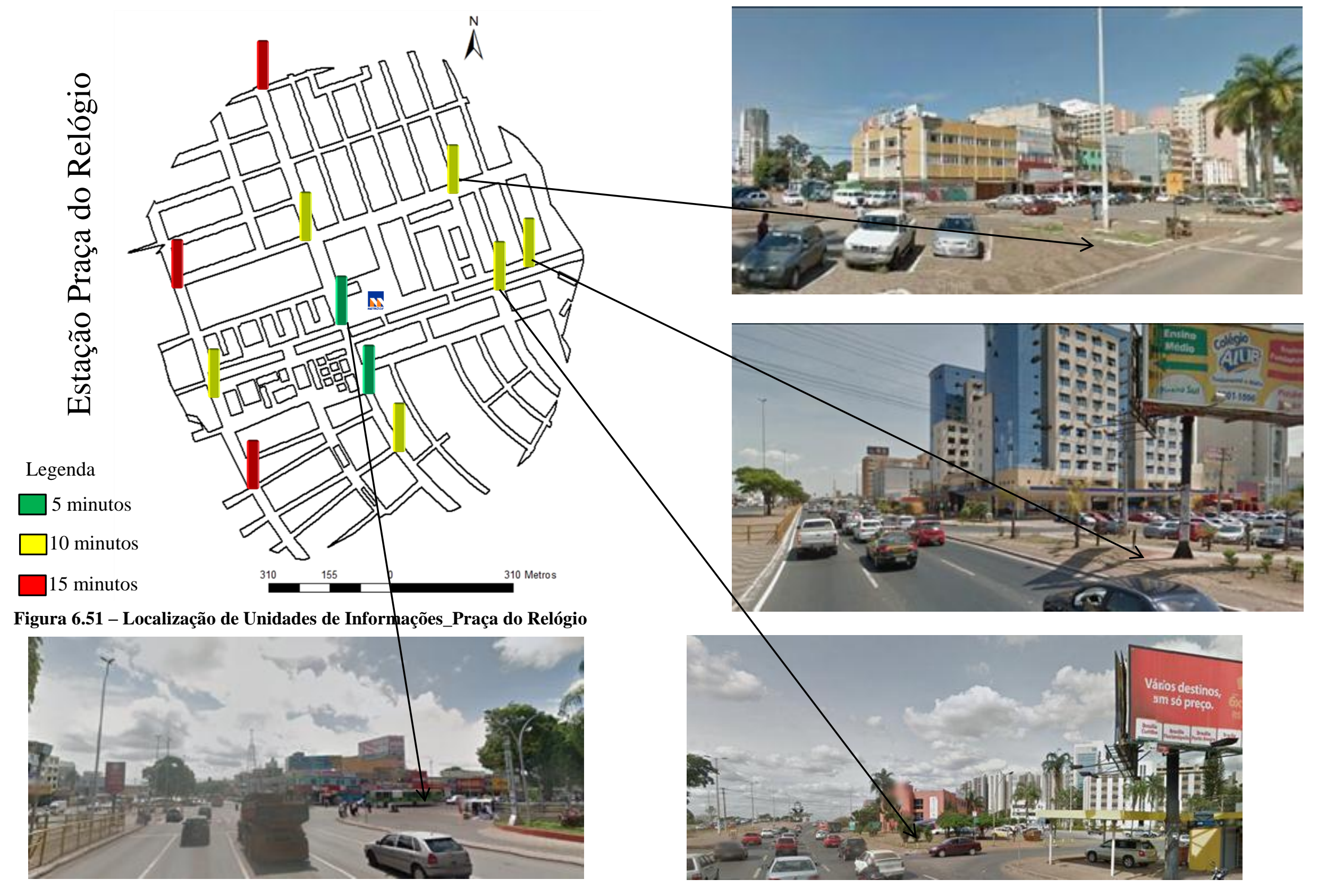




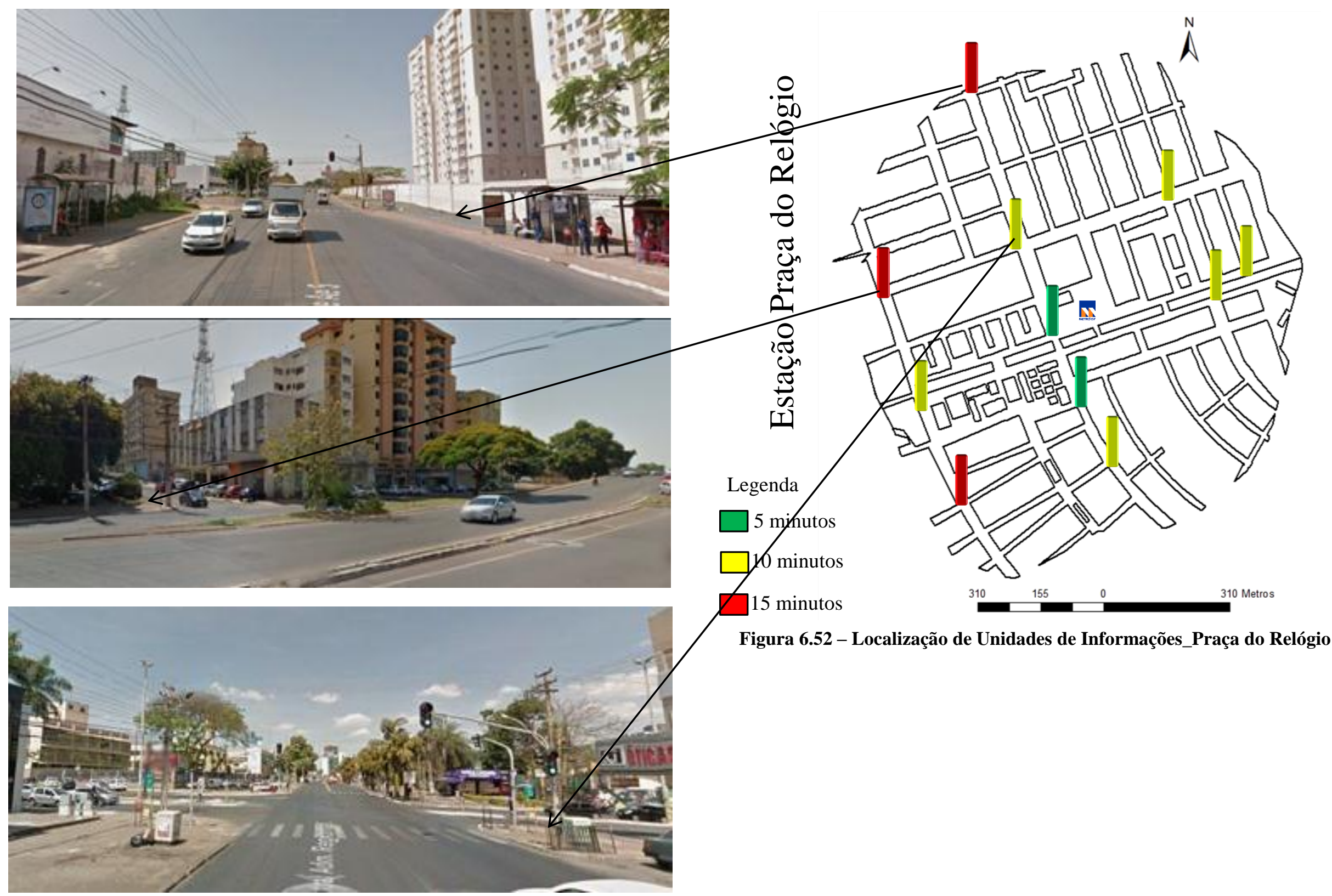




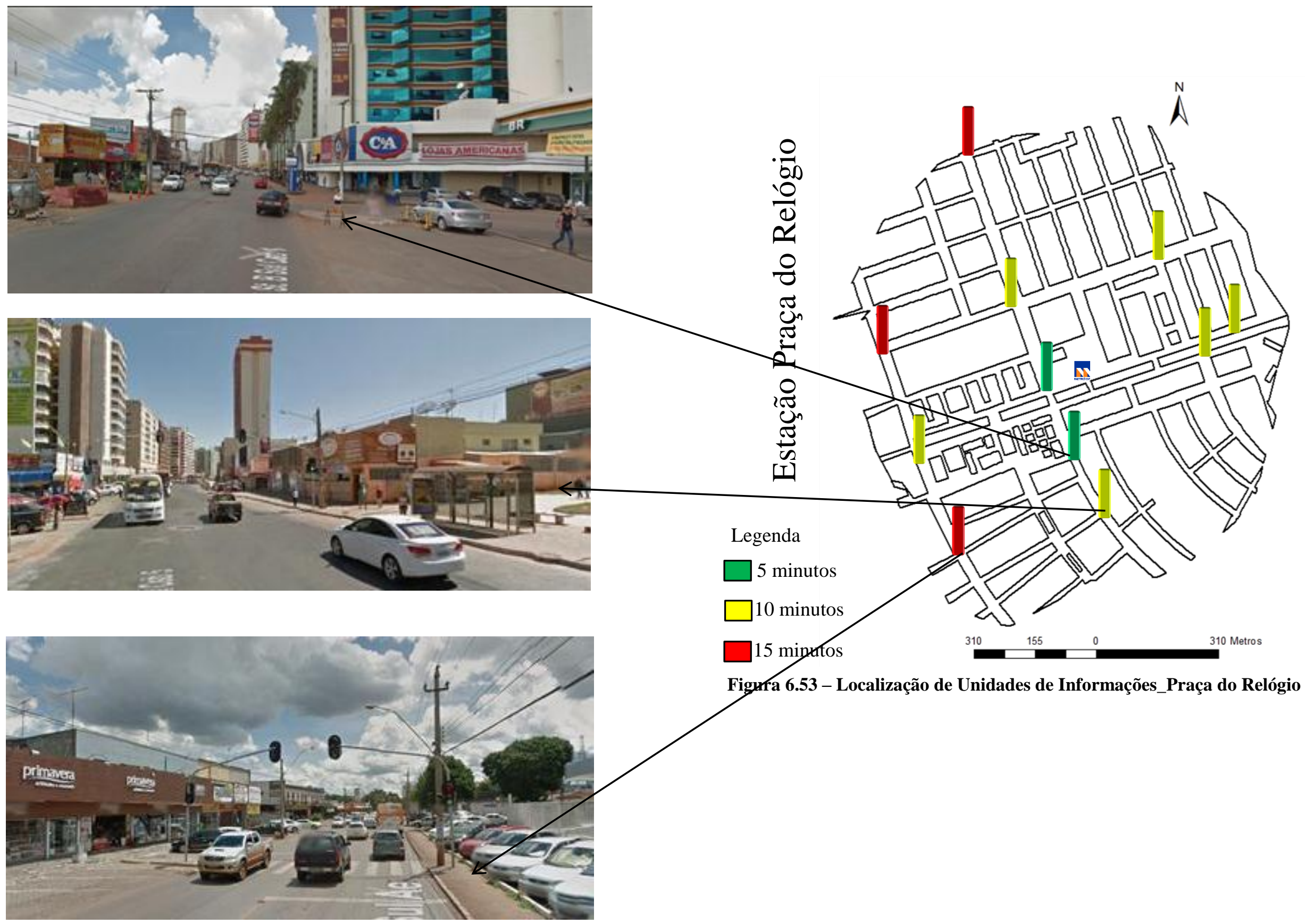




\section{CONCLUSÃO E RECOMENDAÇÕES}

\subsection{CONCLUSÃO}

Uma pessoa para se orientar em qualquer tipo de deslocamento precisa conhecer onde está (localização geográfica) e para qual sentido de movimentação deverá seguir (visualizar previamente informações de rotas/caminhos), porém, para os pedestres em muitas cidades do mundo essa visualização prévia de informações só acontece quando se adquire os mapas das cidades ou se indaga pessoas que transitam pelas ruas, em pouquíssimos lugares no mundo é possível encontrar informações distribuídas em pontos estratégicos, tornando a tarefa do deslocamento mais contínuo, orientado e muitas vezes, mais seguros.

Mediante a aplicação do estudo de caso, foi possível observar que a questão de pesquisa deste estudo (em que medida a localização das informações no espaço urbano afeta a continuidade e orientação do deslocamento do pedestre) é respondida partindo da premissa de que as informações quando bem localizadas proporcionam uma melhor apropriação do espaço e um deslocamento mais contínuo e orientado para os indivíduos. A configuração da cidade e a infraestrutura urbana são os primeiros itens levados em consideração para avaliação de um deslocamento contínuo e orientado, em seguida as informações entram com um viés de corretores de uma confiração urbana que não é propícia para uma legibilidade clara e prévia.

Conforme apontada pelos teóricos urbanos, as distâncias são cruciais para o estímulo do modo de deslocamento a pé. Com áreas menores, as sinalizações tornam-se mais precisas e de fácil visualização aos pedestres. Dessa forma a combinação da setorização funcional e os grandes vazios que Brasília apresenta é um dos fatores mais desestimulantes a circulação de pedestres nos espaços públicos. Desde sua concepção, o deslocamento priorizado na capital foi o modo rodoviário, com foco no automóvel. Avenidas largas e retilíneas com sinalizações horizontais e verticais cortam a cidade de norte a sul, em compensação, o diagnóstico quando se observa o sistema viário para os pedestres, é de péssima qualidade. Jacobs (2011) traz que a calçada só significa alguma coisa quando esta perto de edifícios e/ou outros usos limítrofes e as calçadas quando existentes, são bastante descuidadas, não há continuidade, integração ou mesmo os mínimos para a acessibilidade de pessoas com alguma deficiência motora, transformando o deslocamento a pé em um aborrecimento para os pedestres. 
Em relação às distâncias (físicas e percebidas) no deslocamento a pé, é possível compreendêlas de duas maneiras: o deslocamento parece mais curto em uma rua curva e cheia de coisas para ver do que em uma rua de perspectiva cansativa, ou seja, reta, longa e sem estímulos, que é o caso de ruas nas áreas de influência das estações Guará, Furnas e Shopping.

Jacobs (2011) elenca a diversidade de usos como fator principal para geração de segurança e interação e atratividade para os pedestres. Os pedestres esquecem a distância quando o percurso for interessante, confortável e aprazível em experiências. As áreas de influências das estações Galeria e Praça do Relógio são similares pelas diversidades de serviços e comércios existentes, o deslocamento a pé pode ser feito por trechos, quebrando naturalmente a caminhada, e a atratividade do espaço urbano convida o pedestre a ir de um trecho a outro.

Porém, em relação à escala humana levantada por Gehl (2013), as três estações Guará, Furnas e Shopping estão distantes de apresentarem esse atributo. Já as estações Galeria e Praça do Relógio, apresentam certas preocupações com essa escala, como exemplo, as rotas de pedestres encontradas no Setor Comercial Sul (Galeria), com faixas de pedestres elevadas, piso tátil e larguras de calçadas adequadas e no centro de Taguatinga (Praça do Relógio) com o uso misto do solo e a variedade de comércios proporcionam uma inteiração entre os espaços e as pessoas, ou seja, um espaço urbano mais vivo e convidativo.

O objetivo em encontrar pontos para disponibilizar unidades de informações (mapas, totens) é indicar rotas/caminhos como instrumentos capazes de descrever os espaços que muitas vezes apresentam uma natureza que ainda deve ser compreendida e preenchida de significados e não apenas projetada e preenchida de coisas.

As cinco estações estudadas podem ser classificadas em dois grupos distintos. O primeiro grupo (Guará, Shopping e Furnas) apresenta quase uma ausência de infraestrutura para o pedestre, forte segregação do uso do solo, grandes espaços vazios, pouca identidade, ou seja, as ruas podem ser facilmente confundidas e também poucos pontos estratégicos de unidades de informações com uma pequena exceção da estação Guará que apresentou mais do que seis pontos. O segundo (Galeria e Praça do Relógio) com uma infraestrutura melhor para os pedestres, apresentando rotas com faixas elevadas, uso do solo misto, variedades de comércios, diversidade de pessoas e corredores com pontos estratégicos de informações. 
As vias coletoras ou arteriais que possuem um tráfego intenso e velocidade de $60 \mathrm{~km} / \mathrm{h}$ e $80 \mathrm{Km} / \mathrm{h}$, a falta de segurança principalmente à noite, a falta de infraestrutura, diversidade de uso/atratividade, escala humanizada e sinalização de referência/orientação, agregadas as grandes distâncias de deslocamentos, formam as maiores dificuldades para que haja uma melhor e maior circulação de pessoas nessas áreas. $\mathrm{O}$ caminhar, mesmo não sendo a construção física de um espaço, implica uma transformação do lugar e dos seus significados.

Vale ressaltar que os campos de visão são fundamentais para o posicionamento de unidades de informações, isto é, locais que visualmente serão mais fáceis de serem alcançados a partir de um determinado espaço. A orientabilidade por meio de informações estrategicamente posicionadas modifica culturalmente o significado do espaço e, consequentemente, o espaço em si, transformando-o em lugar, pois simultaneamente se faz a leitura (ato perceptivo) e a escrita (ato criativo) de um território. Conforme exposto por Lynch (2011), as pessoas fazem associações, impregnadas de lembranças e significados, de diferentes partes das cidades, e a cada instante existirá mais uma paisagem esperando ser explorada.

Após preencher o vazio circunstante com uma quantidade estratégica de informações que servem de orientação e legibilidade, reclassificará o espaço urbano que antes era apenas um espaço quantitativo para um espaço qualitativo e, desse modo, o espaço pluridirecionado do caos natural transforma-se em espaço ordenado segundo as indicações de direções claramente identificáveis por meio de unidades de informações (mapas, totens) visíveis no vazio.

Finalmente, em relação ao método, o estudo apresentou uma ferramenta da Sintaxe Espacial (Isovista) que é capaz de analisar a forma urbana por meio de suas permeabilidades e barreiras. As análises propiciam aos planejadores/gestores a possibilidade de testar e aplicar o método para intervenções urbanas no sentido de integrar o pedestre com o sistema de transporte público, permitindo que eles (pedestres) se apropriem do espaço, por meio das unidades de informações espalhadas em pontos estratégicos, articulando seu deslocamento de um ponto do sistema de transporte público ao seu destino final.

Vale reforçar que nesse estudo se utilizou as estações do metrô para a aplicação do método, mas nada impede que o instrumento possa ser aplicado e testado em qualquer outra estação de transporte público. $\mathrm{O}$ instrumento permite ao indivíduo uma maior apropriação do espaço, aos 
gestores e planejadores das cidades, a localização (pontos estratégicos) de unidades de informações e por fim a integração dos pedestres na construção de uma rede de transportes que englobará todos os modos do sistema de transporte (motorizados e não motorizados) assegurando maior integração e inteiração do indivíduo com o espaço urbano e com os outros modos do sistema de transportes existentes.

\subsection{RECOMENDAÇÕES}

A seguir são feitas algumas recomendações para estudos futuros acerca do tema:

Em primeiro lugar, após implementação do método, ou seja, a construção de um sistema de localização de informação para o deslocamento de pedestres, é necessário realizar o monitoramento, levando em conta o comportamento dos pedestres diante as instalações das unidades de informações e isto pode ser feito com a realização da contagem de pedestres que circulam nas áreas de influência; com a identificação dos tipos de informações requeridas; pelo posicionamento das unidades de informações e adaptabilidade dos pedestres na leitura delas como marcos visuais.

Em segundo lugar, identificar por meio da integração do pedestre ao sistema de transportes, como fortalecer e estimular o deslocamento a pé e por consequência à incorporação do modo nos planejamentos das redes de transportes, ou seja, será necessária a identificação dos perfis dos usuários das áreas de influências.

E por último, para o fortalecimento do método, é recomendável também verificar a real percepção do individuo no espaço urbano. A leitura dessa percepção pode vir pelas áreas de conhecimento como: Psicologia; Sociologia; Economia; Geografia; História, entre outras. 


\section{REFERÊNCIAS BIBLIOGRÁFICAS}

Alatuey, E. B.(1994)Sociología de La movilidad espacial: el sedentarismo nómada. Madrid: Centro de Investigaciones Sociológicas/SigloXXI.p. 51-73.

Alcaldía Mayor de Bogotá D.C. (2011) Comportamientos positivos e seguros en la via. BOG-Bogotá Positiva - Gobierno de La Ciudad.

Amidon, E. L; Elsner, G. H. (1968) Delineating landscape view areas: a computer approach, Forest Research Note PSW-180, US Department of Agriculture, Washington, DC

Araújo, E. R. (2006).A mobilidade como objecto sociológico. Disponível em: <https://repositorium.sdum.uminho.pt/bitstream/1822/3913/1/A+Mobilidade+como+objecto+sociologic o.pdf>. Acesso em: 1maio 2014

Barros, A. P. (2006). Estudo exploratório da Sintaxe Espacial como ferramenta de alocação de tráfego. Dissertação de Mestrado. Programa de Pós-Graduação em Transportes. Universidade de Brasília, Brasília.

Barros, A. P. (2014). Diz-me como andas que te direi onde estás: inserção do aspecto relacional na análise da mobilidade urbana para o pedestre. Tese de Doutorado em regime de Co-tutela. Programa de PósGraduação em Transportes. Universidade de Brasília, Brasília.

Barros, A. P. B. G.; Medeiros, V. A. S.; Silva, P. C. M.; Fortes, J. A. S.; Holanda, F. R. B. (2009) Metodologia para a análise da mobilidade na Universidade de Brasília. Anais do XXIII Congresso Nacional de Pesquisa e Ensino em Transportes, Vitória: ANPET.

Barros, A. P. B. G.; Medeiros, V. A. S.(2010) A investigação da mobilidade: ferramentas para estudos intraurbanos e metropolitanos. Anais do Seminário Nacional de Governança Urbana e Desenvolvimento Metropolitano. Natal: UFRN.

Braga, L. M. (2007) Mover-se em Brasília: análises e perspectivas pela ótica da mobilidade espacial urbana acerca do Programa Cicloviário do Distrito Federal. Dissertação de Mestrado - Universidade Federal do Rio de Janeiro, Instituto de Pesquisa e Planejamento Urbano e Regional, $101 \mathrm{f}$.

Brasil. Ministério das Cidades (2007) PlanMob: Construindo a cidade sustentável. Caderno de referência para elaboração de Plano de Mobilidade Urbana. Brasília, Ministério das Cidades.

Beck, M. P. (2011) Arquitetura, Visão e Movimento - o discurso de Paulo Mendes da Rocha na Pinacoteca do Estado de São Paulo. Dissertação de Mestrado em Arquitetura. Programa de Pesquisa de Pós-graduação em Arquitetura da Universidade Federal do Rio Grande do Sul. Porto Alegre.

Câmara G.; Queiroz, G. R. (2000) Arquitetura de Sistemas de Informações Geográfica. In: Câmara, G.; C.; Monteiro, a. m. v. (Org.), Introdução à Ciência da Geoinformação.

Carmo, C. L.; Raia Jr., A. A.; Nogueira, A, D, A, (2012) Teoria da Sintaxe Espacial e Suas Aplicações na Área de Circulação e Transportes. Anais do 5 Congresso Luso-Brasileiro para o Planejamento Urbano, Regional, Integrado e Sustentável. Brasília: Universidade de Brasília, Faculdade de Arquitetura e Urbanismo, v. 1 p. 1-12.

Carmo, C. L. (2013) Efeitos da configuração urbana na acidentalidade envolvendo pedestres em cidades de porte médio. Dissertação de Mestrado. Universidade Federal de São Carlos. UFSCar

Correia, A. H; Martins, R. A. (2008) Fundamentos de Cartografia e GPS. Universidade de Brasília. Instituto de Geociências. Curso de Especialização em Geoprocessamento.

CNI-Ibope (2011) Pesquisa: retratos da sociedade brasileira: locomoção urbana - Brasília: CNI, 49p.

Cutolo, A. F. (2003) UITO - Core Brief - Passenger Information. UITP - Report - Travel Information Handbook

Department of Transport (2002) A review of the effectiveness of personalised journey planning techniques, London, England. Publicado: 25 de outubro de 2002, modificado: 23 de dezembro de 2005. Disponível em: 〈http://www.dft.gov.uk>. Acesso em: 20 de abril de 2014. London, England.

Dursun, P. (2007) Space Syntax in Architectural Design. Proceedings of the 6th International Space Syntax Symposium. Istanbul.

Eck, R. W. (2004) Pedestrian. In MyerKutz, (Eds.), Handbook of Transportation Engineering, (21.3-21.33), McGraw-Hill Companies, Inc.

Eloy, S. (2011) Ferramentas de apoio à análise da geometria do espaço arquitectónico: sintaxe espacial e gramáticas de forma. Revista Aproged no 29, pp. 3-14

Era, R. T. (2012) Improving Pedestrian Accessibility to Public Space through Space Syntax Analysis, Proceedings of the Eighth International Space Syntax Symposium, Santiago, PUC.

Fayumi, B. (2011) Pedestrian Movement and Safety. Urban Transportation Planning and Management. Carleton University Department of Civil \& Environmental Engineering.

Fujitani, M.; Kishimoto T. (2012). A study about the pedestrian distribution in the commercial buildings by the location of stores and the structure of the walking space. In M. Greene, J. Reyes \& A. Castro (Eds.), 
Proceedings: Eighth International Space Syntax Symposium (pp. 8094:1-8094:18). Santiago de Chile: PUC.

Franz, G.; Wiener, J. M. (2005). Exploring isovist-based correlates of spatial behavior and experience. In A. van Nes (Ed.), Proceedings of the 5th International Space Syntax Symposium Delft, NL. TU Delft Press.

Gehl, J. (2013) Cidades Para Pessoas; tradução Anita Di arco. - 1. Ed. - São Paulo: Perspectiva. 262p.

Government of the United States, Department of Transportation - Federal Highway Administration. 2009. Manual on Uniform Traffic Control Devices, 2009 Edition. http://mutcd.fhwa.dot.gov/

Herce, V. M. (2009) Sobre la movilidad em la ciudad: propuestas pra recuperar um derecho ciudadano / Manuel Herce; prólogo Gabriel Dupuy; edición Jorge Sainz. - Barcelona: Reverté, D. L. 328p.

Hillier, B.; Hanson, J. (1984) The Social Logic of Space. Londres: Cambridge University Press.

Holanda, F. R. B. (2002) O Espaço de Exceção. Brasília: Editora Universidade de Brasília.

Jacobs, J. (2011) Morte e vida de grandes cidades. $2^{a}$ Ed. São Paulo: WMF Martins Fontes.

Koch, D. (2012) Isovists Revisited. Egocentric Space, Allocentric Space, and the Logic if the Mannequin. In Proceedings: Eighth International Space Syntax Symposium. Santiago de Chile: PUC.

Lamas, J. (2004) Morfologia Urbana e Desenho da Cidade. Ed. Fundação Calouste Gulbenkian.

Lynch K, (1976) Managing the Sense of Region MIT Press, Cambridge, MA.

Lynch K, (2011) A imagem da cidade/ tradução Jefferson Luiz Camargo. 3ed. São Paulo: Editora WMF Martins Fontes.

Matson, L. (2013) Wayfinding and Walking in London. Transport for London - Inglaterra

Medeiros, V. (2013). Urbis Brasiliae: o labirinto das cidades brasileiras. Brasília: EdUnB.

Melo, L. B., Torres, A. C. S., Jacques, M. A. P. (2004) Estudo dos Fatores que afetam a Velocidade de Caminhada em Faixas de Pedestres Localizadas em Rodovias, Anais do XVIII Congresso da Associação Nacional de Pesquisa e Ensino Transportes - ANPET, Florianópolis.

Melo, F. B. (2005) Proposição de medidas favorecedoras à acessibilidade e mobilidade de pedestres em áreas urbanas. Estudo de caso: O centro de Fortaleza. Dissertação de Mestrado em Engenharia de Transportes. Programa de Mestrado em Engenharia de Transportes, Centro de Tecnologia, Universidade Federal do Ceará.

Mota, D. R. (2013) Modelo Funcional para o Trem Luziânia-Brasília: Uma proposta de Integração e Desenvolvimento Regional. [Distrito Federal] Monografia de Projeto Final - Departamento de Engenharia Civil e Ambiental. Universidade de Brasília. Faculdade de Tecnologia 114 p.

Nogueira, A. D. (2004) Análise sintático-espacial das transformações urbanas de Aracaju (1855-2003). 365 p. Tese. (Doutorado). Faculdade de Arquitetura e Urbanismo, UFBA, Salvador.

Nogueira, A. D. (1998) Morfologia Urbana através da Sintaxe Espacial e do Fluxo de pedestres em território universitário: o campus da UFSCar. 200 p. Dissertação de Mestrado em Engenharia Urbana - Centro de Ciências Exatas e Tecnologia, Universidade Federal de São Carlos.

Novaes, A. G. (2007) Resolução de Problemas de Transporte com Diagramas de Voronoi. XXI ANPET, Panorama Nacional da Pesquisa em Transportes. Rio de Janeiro: Associação Nacional de Pesquisa e Ensino em Transportes.

Özbil, A.; Peponis, J. (2007) Modeling street connectivity and pedestrian movement according to standard GIS street network representation.Proceedings of the 6th International Space Syntax Symposium, Instanbul.

Özbil, A.; Peponis, J.(2012) The effects of urban form on walking to transit. Proceedings of the 8th International Space Syntax Symposium, Santiago, Chile.

Ozer, O.;Kubat, A. (2007) Walking initiatives: a quantitative movement analysis. 6th international space syntax symposium.

Pereira, R. H.; Barros, A. P. B. G.; Holanda, F. R. B.; Medeiros, V. A. S. (2011) O uso da Sintaxe Espacial no desempenho do transporte urbano: limites e potencialidades. Texto para Discussão 1630. IPEA: Brasília.

Pólvora, A. (2007) Mobilidade, transportes e gestão territorial na Área Metropolitana de Lisboa. Disponível em: <http://www.anmp.pt/anmp/div2006/30a/mm/doc/immSesimbra.pdf>. Acesso em: 4 maio 2014.

Portugal, L. S. (2012) Pólos Geradores de Viagens Orientados a Qualidade de Vida e Ambiental: Modelos e Taxas de Geração de Viagens. Rio de Janeiro: Interciência, 748p.

Raford, N.; Ragland, D. R. (2011) Space Syntax: An Innovative Pedestrian Volume Modeling Tool for Pedestrian Safety. e Scholarship Repository, University of California, 2003, Disponível em : http//repositories.cdlib.org/its/tsc/UCB-TSC-RR-2003-11. Acessado em agosto de 2014

Saboya, R. T.; Bittencourt, S; Stelzner, M; Sabbagh, C; Ely, V. H. M. B. - (2011) Padrões de visibilidade, permeabilidade e apropriação em espaços públicos abertos: um estudo sintático.

Sarmento, B. R.; Costa, A. D. L. (2012) Análise do espaço urbano pela Sintaxe Espacial: um olhar sobre a UFPB. Anais do V Congresso Luso-Brasileiro para o Planejamento Urbano, Regional, Integrado e Sustentável. Brasília. 
Silva, A. H. (2008) Determinação da Área de Captação de uma Estação de Metrô por meio da Utilização do Modelo Prisma Espaço-Tempo e Padrões de Viagens. Dissertação de Mestrado - Departamento de Engenharia Civil e Ambiental - Faculdade de Tecnologia - Universidade de Brasília.

Silva, A. S.; Lara, R. (2005) A Reconquista da Rua como Lugar de Convívio Social, In: $1^{\circ}$ Congresso Luso Brasileiro para o Planejamento Urbano Regional Integrado e Sustentável, São Carlos, SP.

Silva, D. (2000) Sistemas Inteligentes no transporte público por ônibus. 143 f. Dissertação - Departamento de Engenharia de Produção, Universidade Federal do Rio Grande do Sul, Porto Alegre.

Silva, Paulo. R. F. A. (2013) Cartografando a construção do conhecimento Cartográfico no ensino da geografia. Tese de Doutorado. Universidade Federal do Rio Grande do Sul. Instituto de Geociências. Programa de Pós Graduação em Geografia. Porto Alegre: IGEO-UFRGS, il. 254f.

Silva, D. C. (2007) Oriente-se! Revista MundoGeo ed. maio 2010. Disponível em http://mundogeo.com/blog/2010/05/14/oriente-se-4/ Acessado em agosto 2014.

Silva, A. N. R. (1998) Sistemas de informações geográficas para planejamento de transportes. Tese - Escola de Engenharia de São Carlos, Docência em Engenharia de Transportes, Universidade de São Paulo, São Carlos, $124 \mathrm{p}$.

Tandy, C. R. V. (1967) The isovist method of landscape survey, in Symposium:Methods of Landscape Analysis Ed. H C Murray (Landscape Research Group, London)

Turner, A.; Penn, A. (1999) Making isovists syntactic: isovist integration analysis. Paperpresented at the 2nd International Symposium on Space Syntax, Brasilia.

United States (US) Department of Transportation, Federal Highway Administration. 2009. "Appendix III, Spending on Bicycle and Pedestrian Facilities and Programs,” National Bicycling and Walking Study: Ten-Year Status Report, Federal Highway Administration. www.fhwa.dot.gov/environment/bikeped/study/index.htm\#nbwftn5

Vasconcelos, E. A. (2012) Mobilidade urbana e cidadania. Rio de Janeiro: Senac Nacional, 216p.

Vukan R. Vuchic. Urban Transit Systems and Technology. New Jersey: John Wiley \& Sons, 2007.

Zhang, L.;Zhuang, Y.; Dai, X. (2012) Um estudo configuracional de pedestre corre em espaço comercial multinível. Estudo de caso de Xangai. In: 8 Simpósio sintaxe espacial Internacional em Santiago do Chile. 